Master's Thesis:

\title{
Ramana Maharshi and the Colonial Encounter
}

By

Alan Edwards

\author{
A thesis \\ submitted to the Victoria University of Wellington \\ in fulfilment of the requirements for the degree of \\ Master of Arts \\ in Religious Studies
}

Victoria University of Wellington 


\begin{abstract}
Recent scholarship on Ramana Maharshi (1879-1950) follows the romanticism of hagiographical literature, presenting him as a purely spiritual and timeless figure, thus ignoring the political contours of colonial India. Scholarly literature, then, has effectively deracinated this internationally acclaimed figure from one of the most fascinating and transformative historical periods of the modern era. The current study seeks to correct ahistorical representations of Ramana Maharshi by considering the historical processes that determined his status as a Maharshi (Great Vedic Seer) and Advaitin. I aim to show that Ramana Maharshi's image as a timeless and purely spiritual figure actually locates him in his historical situation, and further, that his status as a Maharshi (Maharși) and Advaitin reflects the ways in which 'the political' and 'the spiritual' interacted during colonial India. This thesis will delineate the process by which Ramana's status as a Maharshi allowed his religious identity to shift from an unorthodox, localised, and ethnic-sectarian form to one in which he symbolised a religious authority in an orthodox and pan-Hindu way. In a broader context, then, this thesis seeks to address the following question: how, and to what extent, did colonial dynamics affect the ways that Hindus interpreted and represented their religious figures during the nationalist period? Here I will demonstrate that Ramana Maharshi represents a compelling case study in the ways in which Orientalist stereotypes about a 'mystical East' affected the intersection of politics and religion in colonial India.
\end{abstract}




\section{Acknowledgements}

It has been a privilege to work with Dr. Rick Weiss and Dr. Michael Radich on this project. I feel extremely fortunate and grateful to have two excellent mentors - your knowledge, skill and accomplishments have been an inspiration. I thank you both for your invaluable guidance, encouragement and support, and for having been so generous with your time. I would like to specially thank Dr. Weiss for helping me to think about India's colonial period in ways that were significant to the development of this thesis. Many seeds were planted during our meetings that became key ideas and themes of this work. I would like to specially thank Dr. Radich for helping me to approach writing in a more effective way. My writing process and style have benefitted significantly on account of your guidance. I wish to thank the Religious Studies department at Victoria University for providing me with excellent resources and a great environment in which to work. A special thanks goes to Aliki Kalliabetsos for all her help, support and encouragement. I am very grateful to Sekhar Bandyopadhyay for allowing me to attend his brilliant and inspiring course on 'Gandhi, India and the World'.

I would like to thank AsiaNZ: NZASIA for their generous 'Postgraduate Research Award'. This award allowed me to conduct research in India and collect original archival data that greatly contributed to the quality of this work. I would also like to thank the Faculty of Humanities and Social Sciences at Victoria University for their 'Faculty Grant', which allowed me to attend and present a paper at the 2011 AASR Conference in Australia. Many thanks to AASR, the Religious Studies department at the University of Queensland, and the History department at Victoria University for the opportunity to present a paper. I wish to specially thank Adam Bowles at the University of Queensland for his helpful suggestions and hospitality during my visit to Brisbane.

I would also like to thank a list of fellow Postgrads for their encouragement, suggestions and friendship; David Murphy, Cheryl Johansen, Dylan Clark, Zane Mather, Amy Searfross, Eda Czarnecki, Atsushi Iseki, Will Hoverd, Negar Partow, Dan Dowling, Akvilina Cicenaite, and Michael Teitelbaum. Finally, I am immensely grateful to Jasmine Cook-Auckram for her encouragement, support and love. You are an inspiration. 


\section{Table of Contents}

Introduction

Chapter 1: Ganapati Muni and the Maharshi Construct ............................................. 14

1.1. Ganapati Muni: Sanskrit scholar, poet and spiritual adept ................................... 19

1.2. The radical freedom fighter: political representations of Ganapati Muni ..................23

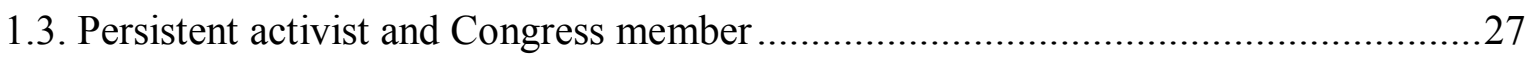

1.4. Ganapati's mission and Ramana as the Rishi Vedic Emperor ..................................... 31

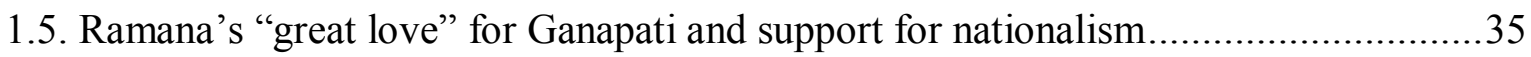

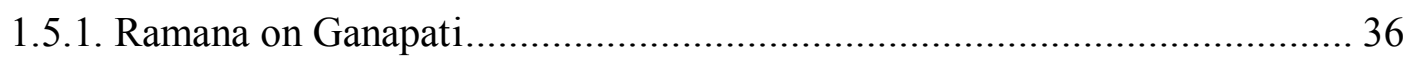

1.5.2. Ramana symbolically endorsing nationalism ................................... 37

1.5.3. Ramana verbally endorsing nationalism ............................................ 39

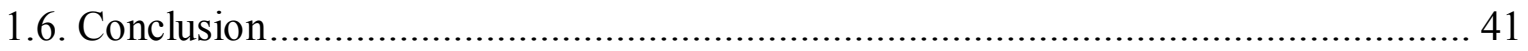

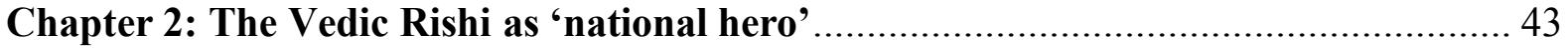

2.1. The appeal of the mythic Maharshi symbol .............................................................. 44

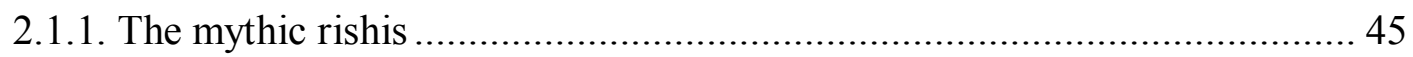

2.1.2. Paul Brunton and "the Maharishee" ................................................... 47

2.2. The 'national hero': Ramana as the living embodiment of Hindu truth ..................... 50

2.2.1. The political pursuits of early biographers ......................................... 52

2.2.2. Political leaders celebrating Ramana................................................ 54

2.2.3. Hindu intellectuals and the Advaita construct ....................................... 57

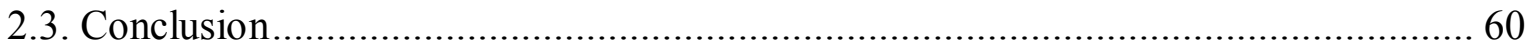

Chapter 3: Framing Ramana's religious identity: Advaitin or Śaiva bhakta? .............. 63

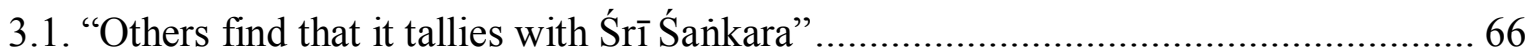

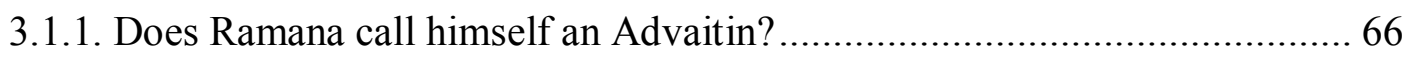

3.1.2 "The consciousness of individuality was very much there" ...................... 69

3.2. "All these different mārgas or sādhanas lead to the same goal" ............................... 74

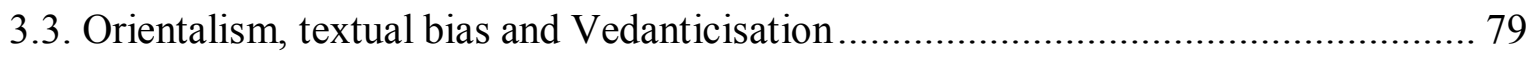

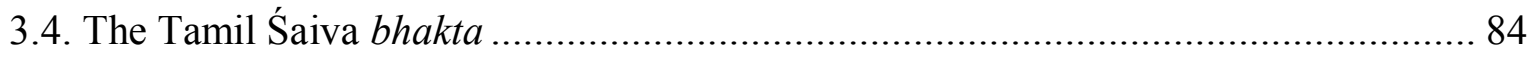

3.4.1. The Periya Purānam and Ramana's 'God-mad' state in Śaiva temples ...... 85

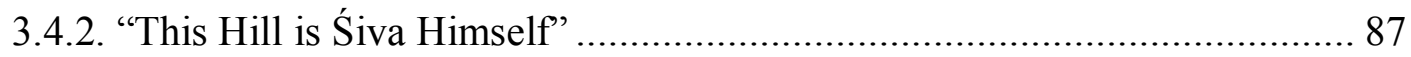


3.4.3. The Tamil Śaiva saints and sacred texts ................................................. 90

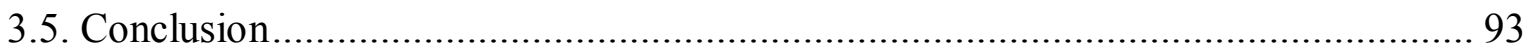

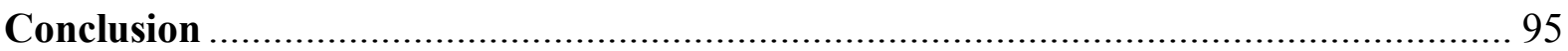

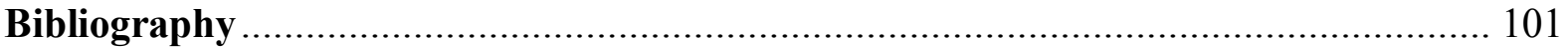




\section{Introduction}

India's colonial encounter with Britain produced a multitude of brilliant political and religious leaders such as Rammohun Roy, Dayananda Saraswati, Swami Vivekananda, Aurobindo Ghose and Mohandas K. Gandhi. Seemingly unique among the array of Indian figures who achieved international acclaim during the colonial period stands Ramana Maharshi (1879-1950), who Aurobindo described as a "Hercules among yogis...who had won glory for India." ${ }^{1}$ This uniqueness stems from the assumption that he was detached from the political sphere and immune to the forces of Hindu reform and Indian nationalism, an assumption that surprisingly is also reflected in scholarship on Ramana Maharshi. In stark contrast to this view, I aim to show that Ramana Maharshi's image as a timeless and purely spiritual figure actually locates him in his historical situation, and further, that his status as a Maharshi (Maharsii) and Advaitin reflects the ways in which 'the political' and 'the spiritual' interacted during colonial India. ${ }^{2}$ In a broader context, then, this thesis proceeds with the following question in mind: how, and to what extent, did colonial dynamics affect the ways that Hindus interpreted and represented their religious figures during the nationalist period?

The current study seeks to correct ahistorical representations of Ramana Maharshi by considering the historical processes that determined his status as a Maharshi and Advaitin. I will argue: (1) that the political ambitions of Ganapati Muni (Ramana's chief disciple) determined Ramana's status as a Maharshi, contrary to the assumption that this status relied solely on the recognition of his alleged spiritual greatness. The mythic appeal of the Maharshi construct then allowed Ramana to participate in nationalist agendas in symbolic ways; foremost among these was the desire to vindicate Hinduism and generate national pride. (2) Ramana's categorisation as an Advaitin was more dependent upon the fruits of Orientalist discourse, Hindu reform and nationalism, than on his alleged 'awakening' at sixteen, as is invariably assumed in devotional literature and scholarship alike.

\footnotetext{
${ }^{1}$ Laxmi Narain, ed., Face to Face with Sri Ramana Maharshi: Enchanting and Uplifting Reminiscences of 160 Persons (Hyderabad: Sri Ramana Kendram, 2007), 31.

${ }^{2}$ The term Maharshi signifies a 'Great Rishi (Vedic Seer)'. I characterise the rishis in section 2.1.1. The term Advaitin to refers to a proponent of Advaita Vedānta, an important school of Hindu philosophy. I characterise Advaita Vedānta in the introduction to Chapter 3.
} 
This thesis will therefore challenge the assumption that Ramana is most accurately categorised as an Advaitin. I will instead argue that Ramana's ontology and soteriology are inclusivistic, rather than exclusively Advaitin. Moreover, Ramana ought to be primarily identified with the Tamil Śaiva bhakti tradition. Here I emphasise Ramana's religious praxis, rather than relying solely on his written works. Ramana's devotional relationship with Arunachala, a hill that Tamil Śaivas hold to be Śiva manifest, is central to this claim. There are multiple examples in which Ramana referred to Arunachala as something uniquely special and distinct from the rest of the phenomenal world. These references create tensions with claims to an exclusive Advaitin worldview, but are compatible with a bhakti framework.

In broader terms, this thesis represents a case study in the ways which Orientalist stereotypes about a 'mystical East' affected the intersection of politics and religion in colonial India. In this context, we are able to engage with the historical processes that allowed Vedic and Vedāntic ideals to emerge as the definitive characteristics of a single, homogenous Hinduism, and how these ideals came to play a significant role in nationalist discourse and political agendas. This case study also demonstrates the ways that scholarship can misinterpret and misrepresent religious figures because of the failure to recognise the presence of Orientalism, and because of the failure to maintain critical distance when dealing with the rhetoric of devotional literature.

\section{Review of prior scholarly literature}

Surprisingly, scholarship on Ramana follows the rhetoric of devotional literature and ignores the political contours of India and Britain's colonial encounter. Scholarship presents Ramana as a purely spiritual and timeless figure in a way that mirrors Orientalist stereotypes about a mystical East. By 'timeless', I am referring to that which appears ancient and unchanging, and which denies significance to a specific historical context. Scholarly literature, then, has effectively deracinated this internationally acclaimed figure from one of the most fascinating and transformative historical events of the modern era. Further, in 
cases such as Thomas Forsthoefel and Arvind Sharma, a type of reverent, rather than critical, scholarship may be seen. ${ }^{3}$

In his brief biographical treatment, David R. Kinsley describes the major episodes of Ramana's life following a brief survey of nineteenth century Hindu reform and Indian nationalism. Kinsley correctly observes: "In the history of Hinduism, the nineteenth and twentieth centuries have been dramatic in maintaining and redefining Hindu self-identity for a vast number of Hindus."4 Kinsley's first direct reference to Ramana, however, announces that "one is almost totally unaware of these broader historical developments...His life and teachings have an air of timeless, classic structure. They seem as appropriate to twentieth century Hinduism as they do to first century Hinduism." ${ }^{, 5}$ Kinsley then goes on to firmly tie Ramana to India's "ancient roots." ${ }^{\prime 6}$ Kinsley's scholarly contribution clearly stereotypes the romanticised rhetoric of hagiography.

David Smith's portrayal also echoes this romanticism. Smith describes Ramana as one who enjoyed a "continual state of bliss."7 Apart from erroneously interpreting the transformative experience that inspired Ramana to leave home and journey to Arunachala as "a near-death experience," Smith concludes his brief depiction by declaring that he "was renowned for his publicity, his silence, and his public manifestations of supreme bliss." 8 Smith's treatment fails to offer any insight, rather it adds to the already established romanticism surrounding Ramana.

Andrew O. Fort and Arvind Sharma both treat Ramana as a purely spiritual figure on account of his reputation as a jīvanmukti (a concept which signifies that the individual has attained spiritual liberation prior to the death of the body). Fort implies that Ramana was disconnected from his historical situation

\footnotetext{
${ }^{3}$ John Grimes is another example of a scholar who has produced a clearly reverential work on Ramana, but to the extent that it places him in an entirely different category. Despite analysing Ramana's metaphysics in a scholarly way, Grimes' work fails to draw on any scholarly literature including that on Ramana. The tone of the work is highly devotional, in fact, Grimes dedicates his book to 'Bhagavan Sri Ramana Maharshi'. Typically, Grimes presents Ramana's life and teachings, as well as his "Great Awakening" as "in perfect accordance with the essence of Advaita's philosophical teachings". See John Grimes, Ramana Maharshi: the Crown Jewel of Advaita (Varanasi: Indica Books, 2010), 9-10.

${ }^{4}$ David R. Kinsley, Hinduism: a Cultural Perspective (New Jersey: Prentice-Hall, 1982), 44-45.

${ }^{5}$ Ibid., 46. Emphasis mine.

${ }^{6}$ Ibid.

${ }^{7}$ David Smith, Hinduism and Modernity (Oxford: Blackwell, 2003), 175.

${ }^{8}$ Ibid., 176.
} 
by claiming that he was "committed more to self-realisation than social reform." 9 Sharma goes further by denying any relevance to the forces of the colonial context. Sharma argues: "The one person who could credibly be identified as a jīvanmukti, namely, Ramana Maharshi, and thus bear witness to neo-Hindu philosophical religious triumphalism, turns out to be the one figure of neoHinduism from whom nothing in support of even Indian nationalism could be extracted even at the height of the independence struggle." ${ }^{10}$ Sharma immunises Ramana from external influence in two ways: first, by categorising him as a jīvanmukti, which implies that Ramana was ultimately not of, or in this world; and second, by denying Ramana any participation in or concern for India's most important political event in his lifetime.

I argue against Sharma that Ramana passively participated in nationalist politics in two ways. First, I demonstrate his role as a symbolic religious figure, which conjured an idealised spiritual authority of an imagined Golden Age, i.e. the rishi (rși). This role extended to his construction as a living embodiment of Hindu truth, which aimed at vindicating a single, unified Hinduism, and generating national pride. Second, Ramana endorsed nationalism through an array of symbolic gestures and acts, such as personally raising the Indian flag at his ashram on Independence Day, along with advising visitors to his ashram to follow Gandhi's example.

Thomas A. Forsthoefel also presents Ramana as a purely spiritual and ahistorical figure, confining his treatment to philosophical analysis of Ramana's supposed non-dualism. Like that of Kinsley and Smith, Forsthoefel's rhetoric at times resembles the romanticism of hagiographical literature, as the following illustrates: "For over twenty years, he maintained silence...to sustain quiet absorption in the Self." 11 A deeper investigation into the activities of Ramana's first twenty years at Arunachala clearly demonstrate this depiction to be an exaggeration and romanticisation.

\footnotetext{
${ }^{9}$ Andrew O. Fort, Jivanmukti in Transformation: Embodied Liberation in Advaita and NeoVedanta (New York: State University of New York Press, 1998), 134-35.

10 Arvind Sharma, "Jivanmukti in Neo-Hinduism: the Case of Ramana Maharshi," Asian Philosophy 15, no. 3 (2005): 218.

${ }^{11}$ Thomas A. Forsthoefel, Knowing Beyond Knowledge: Epistemologies of Religious Experience in Classical and Modern Advaita (Burlington: Ashgate Publishing Company, 2002), 132.
} 
Forsthoefel argues that Ramana "liberates Advaita from its local context,"12 and expounds a brand of non-dualism that "transcends the social and cultural settings of South Asia." ${ }^{13}$ He further claims that Ramana's emphasis on an "internalist epistemology" "ushers in a universalism that is in harmony with the premises of Advaita." ${ }^{14}$ Forsthoefel insists that "the key to such universalism is experience, purged of all cultural accretions, including tradition and parampara (lineage)." 15 Where Sharma had depicted Ramana as completely untouched by and removed from nationalism, Forsthoefel goes further, deracinating Ramana and his supposed Advaitin worldview entirely from any context whatsoever. In other words, Forsthoefel's analysis allows no scope for external forces to shape Ramana's life and teachings. Forsthoefel bases his argument on the premise that Ramana's alleged 'awakening' at sixteen (which according to Forsthoefel, "is fascinating on account of its apparent absence of doctrinal content or religious training,"16) corresponds exclusively to Advaita Vedānta.

Forsthoefel claims that he does not want "to argue for the correctness of the perennialism position," but "instead show that Ramana's life and teaching implicate a perennial position." ${ }^{17}$ However, I suggest that his agenda is to participate in the debate on mystical experience, and in doing so, he manipulates Ramana's example to circumvent the constructivist argument, namely, that all experiences are intentional and constructed, and thus there are no pure or unmediated experiences. ${ }^{18}$ The perennialist rhetoric confirms Forsthoefel's agenda. According to Forsthoefel, Ramana's "liberating experience" equates to a "universal, trans-cultural phenomenon," a "mystical core experience", and one "at the heart of all religions." 19

In contrast to Ramana's internalism and the support that it affords the Advaita worldview, Forsthoefel refers to Śankara, the founder of Advaita Vedānta. Forsthoefel holds that Śankkara relied on "external circuitry" (i.e. sacred

\footnotetext{
12 Ibid., 124.

${ }^{13}$ Ibid., 155.

${ }^{14}$ Ibid., 139.

15 Ibid., 129.

16 Ibid.

${ }^{17}$ Thomas A. Forsthoefel, "Weaving the Inward Thread to Awakening: the Perennial Appeal of Ramana Maharshi," Horizons 29 (2002): 243.

${ }^{18}$ Steven T. Katz, Mysticism and Philosophical Analysis (New York: Oxford University Press, 1978), 22-27.

${ }^{19}$ Forsthoefel, "Weaving the Inward Thread to Awakening," 242.
} 
texts, the guru, adhikāra, varṇāśramadharma, karma etc.), "socially established doxastic practices, in the main affirming orthodox patterns of culture and renunciation." ${ }^{20}$ Forsthoefel concludes: "These externalist emphases actually lock Advaita to a local context." ${ }^{21}$ His intention here is obvious; he wishes to demonstrate that Ramana, on the other hand, "liberates Advaita from its local context," 22 and further, to imply that Ramana's example liberates religious experience from contextual influence. This, according to Forsthoefel, allows for a universalistic and perennialist claim that circumvents the constructivist thesis.

I claim that Forsthoefel's thesis is refutable in two ways. First, I show that Ramana's alleged 'awakening' was not definitively compatible with Advaita, but rather compatible with diverse Hindu metaphysical schools, including dualistic models. Second, I argue that Ramana's categorisation as an Advaitin depends upon an elitist construct motivated by nationalistic agendas. If one wishes to categorise Ramana as an Advaitin, one must acknowledge that the Advaita in question refers to a construction of Hinduism that was shaped by the historical processes of colonial India, thus rendering any ahistorical analysis problematic.

Wilhelm Halbfass' brief paragraph on Ramana is largely predictable with the exception of a striking concluding sentence. Halbfass begins by presenting Ramana (together with Sri Ramakrishna Paramahansa) as an "outstanding representative" of "Hinduism as the religion of experience." 23 Halbfass then claims that Ramana "represents" an "austere type of 'pure' Advaita Vedānta" which corresponds to "the Śankkara school." ${ }^{24} \mathrm{He}$ further states that Ramana's teachings are void of "attempts to apply Vedānta to the problems of the modern world, or of a concordance of religions." ${ }^{25}$ However, Halbfass appears to then catch himself, as he follows this with somewhat of a disclaimer: "This does, of course, not mean that there is no connection between Ramana Maharshi and his historical situation. ${ }^{, 26}$ While this statement allows Halbfass to avoid falling into the trap of portraying Ramana as 'timeless', he makes no attempt to qualify or

\footnotetext{
${ }^{20}$ Ibid., 245.

21 Ibid.

22 Ibid.

${ }^{23}$ Wilhelm Halbfass, India and Europe: and Essay in Understanding (Albany: State University of New York Press, 1988), 384.

${ }^{24}$ Ibid.

25 Ibid.

${ }^{26}$ Ibid.
} 
elaborate on this claim, except to provide a footnote that refers to Ramana's several years at Christian mission schools in Madurai, during which time he acquired knowledge of the Bible. ${ }^{27}$ In many ways, the current study begins exactly where Halbfass' treatment of Ramana left off, and in doing so, critiques Halbfass' preceding descriptions of Ramana as misrepresentative.

As the above review shows, there is little secondary literature on Ramana. More generally scholars have simply ignored him, and probably for several reasons. I surmise that the large number of important figures who were politically active and motivated during the colonial period has overshadowed Ramana, a figure previously assumed to be apolitical. Further, since the events at Ayodhya in December 1992, ${ }^{28}$ the trend of South Asian historical scholarship has been to focus on the more extremist forms of Hindu nationalism. In addition, Ramana resided in a small backwater town in Tamil Nadu, as opposed to one of the major cities, and never travelled. Also, compared to Vivekananda, Aurobindo, Gandhi et al., his written works are very few, comprising a mere single volume. These factors might allow his contribution to the period to appear only minimally important, but as I will show, his symbolic role as an exemplar of Hindu spirituality participated in the context of nationalism in several significant ways, such as providing a source of national pride and propounding an inclusivistic brand of Hinduism that contributed to the construction of a monolithic, pan-Indian religion.

\section{Orientalism: the East as Mystical, Otherworldly and Timeless}

At the most rudimentary level, Orientalism refers to the ways in which Europeans (or Westerners) understood, described and structured their experience of the Orient'. ${ }^{29}$ In the context of colonial India, Orientalist discourse was freighted with a set of assumptions which had a tremendous impact on the cultural and political landscape. Here I follow Richard King, who asserts: "The presuppositions of the Orientalists cannot be underestimated in the process whereby nineteenth and twentieth century Indians have come to perceive their own identity and culture

${ }^{27}$ Ibid., 567. See footnote 36.

${ }^{28}$ The Babri Mosque in Ayodhya was destroyed by Hindu activists 6 December 1992, resulting in communal riots. The mosque occupied the traditional birthplace of the Hindu god Rama.

${ }^{29}$ Edward Said, Orientalism (London: Routledge \& Kegan Paul, 1978), 1; S. N. Balagangadhara, “Orientalism, Postcolonialism and the 'Construction' of Religion," in Rethinking Religion in India, eds. Esther Bloch, Marianne Keppens and Rajaram Hegde (London: Routledge, 2010), 138. 
through colonially crafted lenses." 30 The aim of this study, however, is not to participate in the debate on Orientalism, nor is it an attempt to cover the breadth and complexity of Orientalism. Instead, I include this section - which introduces the specific Orientalist discourses that appear in the historical processes that shaped Ramana - due to the consistency with which Orientalism occurs in the chapters to follow. Broadly speaking, I focus on a brand of Orientalist discourse that assumed India to be the opposite of Europe, and then described it such through a series of romanticised stereotypes, such as mystical and otherworldly. ${ }^{31}$ I also draw on the role of Orientalist discourse that contributed significantly to the colonial construction of Hinduism as a single, homogenous, world religion. ${ }^{32}$

The key themes of Orientalist discourse at stake here may be separated into three categories. First, we see the dichotomy of East and West, in which Orientalists described India as the "inverse" of the West. ${ }^{33}$ For example, the West assumed dominion over the material, political, and scientific spheres, while the East was defined as spiritual, unchanging, effeminate and traditional. In Chapter One we see this dichotomy influence hagiographers of Ramana, who presented him - 'the Great Rishi' - as purely spiritual in order to legitimise his lofty status, despite the extent to which the political sphere both interested and shaped Ramana, and further, despite the traditional involvement of the rishis in worldly and political activities. The manner in which hagiographers portrayed Ramana in an 'Orientalised' way reflects a broader current, in which Hindu reformers such as Vivekananda remoulded the concept of the rishi along Orientalist lines.

Second, we see a form of romantic Orientalism, which portrayed India as mystical, otherworldly, ancient and timeless. ${ }^{34}$ These stereotypes appealed to diverse groups during the colonial period, yet for different reasons. Among these were the Romanticists, who yearned to be spiritually guided by the East; ${ }^{35}$ the

\footnotetext{
${ }^{30}$ Richard King, Orientalism and Religion: Postcolonial Theory, India and 'the Mystic East' (London: Routledge, 1999), 107.

${ }^{31}$ Ronald Inden, Imagining India (Oxford: Blackwell Publishers, 1990), 3-4, 66-67; Richard King, Orientalism and Religion, 92, 111.

${ }^{32}$ King, Orientalism and Religion, 100, 129; Richard King, "Colonialism, Hinduism and the Discourse of Religion," in Rethinking Religion in India, eds. Esther Bloch, Marianne Keppens and Rajaram Hegde (London: Routledge, 2010), 101-103.

${ }^{33}$ King, Orientalism and Religion, 111.

${ }^{34}$ Inden, Imagining India, 66-68, 93-95; King, Orientalism and Religion, 91-93, 96-98, 119.

${ }^{35}$ King, Orientalism and Religion, 118.
} 
'modern' British colonisers, who wished to justify their political rule; ${ }^{36}$ and Hindu reformers, such as Vivekananda, who used them in anti-colonial strategies. ${ }^{37}$ In Chapter Two we see these romanticised stereotypes at play in the ways that Paul Brunton characterised his encounter with Ramana in the early 1930s. Brunton's $A$ Search in Secret India contributed greatly to Ramana's popular image among Westerners and educated Indians as a purely spiritual, otherworldly and timeless figure.

Third, we see the role of Orientalist discourse in the emergence of a single, homogenous Hinduism, which at first facilitated Britain's colonial administration and rule, but then also allowed Indian leaders to promote national unity. ${ }^{38}$ The Orientalist tendency to characterise Hinduism as mystical, and the (Protestant) assumption that religion is located in scripture (in this case the Upanișads) contributed to a process of Vedanticisation, in which Advaita Vedānta emerged as the most prestigious form and central doctrine of Hinduism. ${ }^{39}$ Hindu reformers such as Rammohun Roy, Vivekananda and S. Radhakrishnan were also heavily influential in this process, which both depended on and contributed to the construction of a single, homogenous Hinduism. We see this process of Vedanticisation figure largely in Ramana's construction as an Advaitin, which I discuss in Chapters Two and Three.

As expected, the Orientalism at play here cannot be disconnected from the colonial - or 'imperial' - agenda of the British. ${ }^{40}$ As Peter van der Veer states: "In the eyes of Orientalists, the civilisations of the East were great in the past but are decadent at present and thus in need of Western domination." ${ }^{41}$ Thus, Edward Said's stance on Orientalism as an imperial instrument, i.e. "as a Western style for dominating, restructuring and having authority over the Orient", is indeed relevant. ${ }^{42}$ Though as the current study demonstrates, not only did Orientalist discourse contribute to British imperialism, it also served as a defining feature of anti-imperial strategies, as seen, for example, in Dayananda Saraswati, Swami

\footnotetext{
${ }^{36}$ Ibid., 98.

${ }^{37}$ Ibid., 93.

${ }^{38}$ Ibid., 105-06.

${ }^{39}$ Ibid., 96, 101, 129

${ }^{40}$ Peter van der Veer, Imperial Encounters: Religion and Modernity in India and Britain (New Delhi: Permanent Black, 2006), 113.

${ }^{41}$ Peter van der Veer, Religious Nationalism: Hindus and Muslims in India (Berkely: University of California Press, 1994), 56-57.

${ }^{4}$ Said, Orientalism, 3.
} 
Vivekananda and Gandhi. ${ }^{43}$ This tension between imperialism and antiimperialism as functions of Orientalism, I suggest, poses a challenge to Said's thesis, likely because Said's analysis emphasises the Middle East and largely ignores India.

\section{Outline}

To recapitulate, this thesis aims to correct the trend of ahistorical and philosophical scholarship on Ramana Maharshi by considering the historical processes that determined his status as a Maharshi and Advaitin. To support my claim that the forces of India's colonial encounter deeply shaped Ramana, my thesis proceeds as follows:

Chapter 1 argues that Ganapati's act of transforming Ramana - an ascetic Tamil Shaiva - into a Maharshi was motivated to serve his political agenda, which was intrinsically connected to India's struggle for liberation. It further argues that Ramana's high regard for Ganapati and his political ambition demonstrates a willingness to participate in Ganapati's agenda. Evidence presented here of Ramana symbolically and verbally endorsing Indian nationalism further supports this claim, which in addition, directly challenges Arvind Sharma's depiction of Ramana as "the one figure of neo-Hinduism from whom nothing in support of even Indian nationalism could be extracted even at the height of the independence struggle." 44

Chapter 2 delineates the process by which Ramana's reputation as a Maharshi allowed him to acquire status as both 'national hero' and Advaitin. I argue that Hindu intellectuals and political leaders celebrated and promoted Ramana as a living embodiment of Hindu truth in order to vindicate Hinduism in its form as national religion - and generate national pride. I also demonstrate that Ramana's categorisation as an Advaitin was deeply connected to these currents, along with an additional process, namely, the Vedanticisation of Hinduism.

Chapter 3 argues that Ramana's categorisation as an Advaitin was more dependent upon the fruits of Orientalism, Hindu reform and nationalism, than on his alleged 'awakening'. I further argue that Ramana's ontology and soteriology

${ }^{43}$ King, Orientalism and Religion, 86, 93, 112; Inden, Imagining India, 38.

${ }^{44}$ See above. 
are inclusivistic, reflecting ideologies pertinent to the construction of Hinduism during the colonial period. After discarding the Advaitin label I claim that Ramana ought to be primarily identified with the Tamil Śaiva bhakti tradition.

\section{Sources}

Apart from the scholarship already surveyed, I rely on Ramana's collected works, which include: Nān Yār? (Who am I?); Upadeśa Sāram (Essence of Teaching); Uḷlatu Nārpatu (Reality in Forty Verses); Vicāra Sañgraham (Self-Enquiry); and Śrī Aruñācala Stuti Pañcakam (Five Hymns to Arunachala). ${ }^{45}$ I have relied on English translations of these works, which highlights a limitation of this study. I have also drawn from several compilations of dialogues between Ramana and devotees. The most comprehensive of these are Talks with Sri Ramana Maharshi (covering 1935-39), and Day by Day with Bhagavan (covering 1945-47). ${ }^{46}$

As there is a dearth of both scholarship and primary sources, I have also drawn heavily from a vast corpus of devotional literature, in particular, the recently released eight volume hagiography, Arunachala's Ramana: Boundless Ocean of Grace. ${ }^{47}$ This work has been supplemented by numerous accounts from reminiscences of Indian and Western devotees. Devotional literature functions as both a primary and a secondary source depending on the analytical context. Several of these works were originally written in Tamil or Telugu, and again I have relied on English translations.

Finally, as my analytical framework here is historical, I have examined scholarly work on nineteenth century Hindu reform and Indian nationalism, focusing primarily on the role of Hinduism in the latter. In this context, I emphasise key religious and political discourses that played decisive roles in shaping Ramana, such as Vedic Aryanism, the rishi ideal and the Vedanticisation of Hinduism. Finally, I refer to the use and role of Hindu religious symbols in unifying and mobilising the masses of India, as is most notably seen in the case of

\footnotetext{
${ }^{45}$ Arthur Osborne, ed., The Collected Works of Sri Ramana Maharshi (Tiruvannamalai: Sri Ramanasramam, 2004). Note that there are various translators who contributed to this collection. In several individual works, the translator is not stated. T. M. P. Mahadevan and K Swaminathan are responsible for the majority of titles mentioned above.

46 Munagala S. Venkataramiah, Talks with Sri Ramana Maharshi (Tiruvannamalai: Sri Ramanasramam, 2006); A. Devaraja Mudaliar, Day by Day with Bhagavan (Tiruvannamalai: Sri Ramanasramam, 2002).

47 Arunachala's Ramana: Boundless Ocean of Grace, 8 vols. (Tiruvannamalai: Sri Ramanasramam, 2007).
} 
Gandhi. This highlights a climate of receptivity to religious symbols, like the mythic Maharshi during the nationalist project.

\section{A brief biographical sketch}

Ramana Maharshi was born Venkataraman Iyer in Tiruchuli, Tamil Nadu, 30 December 1879. In 1896, at the age of sixteen, Venkataraman became suddenly gripped by the fear of death, an event that culminated in his alleged 'awakening'. This transformative experience and his behavioural response is described in greater detail in the body of the thesis, as it is central to my claim that his categorisation as an Advaitin is not dependent upon his alleged 'awakening'.

Approximately two months after this transformative experience, Venkataraman left his family home in Madurai for Arunachala where he acquired the name Brahmana Swami. ${ }^{48}$ He resided at numerous places on and at the base of Arunachala until his death in 1950. During this fifty-three year period he could never be persuaded to go more than two miles from the mountain. ${ }^{49}$ Ramana's devotional relationship to Arunachala is explored in detail in the body of the thesis, as it highlights the dominant role of the Tamil Saiva bhakti tradition in his life.

In 1907, Ganapati Muni (1878-1936), a renowned Sanskrit scholar and poet who would become Ramana's chief disciple, approached Brahmana Swami to learn about the true nature of tapas (spiritual austerities). Following this encounter Ganapati Muni lauded Brahmana Swami as 'Bhagavan Sri Ramana Maharshi'. The focus on Ganapati Muni's involvement in the liberation struggle in Chapter One will demonstrate the political motivation inherent in this event.

The factor that contributed most to Ramana's pan-Indian and international popularity was the publication of Paul Brunton's A Search in Secret India, in 1934. Its romanticised and Orientalist rhetoric attracted scores of visitors from all over India and the West to see "the Maharishee" in his "forest hermitage" at "the foot of a sacred Hill". ${ }^{50}$ Carl Jung exemplifies the extent of Brunton's influence. Jung described Ramana as "a true son of the Indian earth," whose "life and teachings" represent "the purest of India," adding that they are "not only

${ }^{48}$ Osborne, Ramana Maharshi and the Path of Self-Knowledge, 25.

${ }^{49}$ Godman, Be As You Are: The Teaching of Sri Ramana Maharshi, 2.

${ }^{50}$ Paul Brunton, A Search in Secret India (London: Ryder and Co., 1947). 
important for the Indian but also for the Westerner."51 Jung then placed Ramana in a category of India sages who "not only remind us of the thousands of years old spiritual culture...but also directly embody it."

Amongst the visitors to Sri Ramanasramam (Ramana's ashram) in the second half of the 1930s were W. Y. Evans-Wentz, Somerset Maugham, Paramahansa Yogananda and S. Radhakrishnan. Radhakrishnan portrayed Ramana as "a living embodiment of God-centred life, a perfect image of the life divine in the mirror of human existence." ${ }^{53}$ Intimate Gandhian collaborators such as Rajendra Prasad, Jamnalal Bajaj and C. Rajagopalachari were also among the visitors. According to the editor of Gandhi's collected works, K. Swaminathan, Gandhi himself tried on three separate occasions to visit the ashram. ${ }^{54}$

Ramana's popularity continued to grow until his death in 1950, an event that attracted 40,000 people to his ashram. ${ }^{55}$ A year earlier, U. S. magazine LIFE published a romanticised ten page article on Ramana. Apart from statements which claim that Ramana "was practically born a yogi," we are also told that "the Maharshi was above and beyond politics," and on "a different plane altogether than Gandhi." $" 56$ The New York Times printed two obituaries on Ramana, both of which depicted him as a genuine saintly figure. ${ }^{57}$ Apart from demonstrating him to be an important figure, these above depictions in devotional literature, scholarship and popular media present Ramana in highly romanticised ways. Overall, these representations have immunised Ramana from the forces of the colonial encounter.

\footnotetext{
${ }^{51}$ Carl G. Jung, "Sri Ramana and His Message to Modern Man", in Golden Jubilee Souvenir (Tiruvannamalai: Sri Ramanasramam, 1946), 114-117.

52 Ibid., 116.

${ }^{53}$ S. Radhakrishnan, "Bhagavan Sri Ramana: Sustainer of Spiritual Reality", in Golden Jubilee Souvenir (Tiruvannamalai: Sri Ramanasramam, 1946), 30.

54 Suri Nagamma, Letters from Sri Ramanasramam vol. I \& II, trans. by D. S. Sastri (Tiruvannamalai: Sri Ramanasramam, 2006), 372.

55 S. S. Cohen, Guru Ramana (Tiruvannamalai: Sri Ramanasramam, 2003), 158.

${ }^{56}$ Winthrop Sargeant, "Holy Man,” in Life Magazine, May 30, 1949. http://books.google.com/books?id=1k4EAAAAMBAJ\&pg=PA92\&source=gbs_toc_r\&cad=2\#v=0 nepage \&q\&f=false (accessed 25 June, 2010)

57 See New York Times, April 15, 1950, p. 15; and "Special" to the New York Times, April 16, 1950, p. 105.
} 


\section{Chapter One \\ Ganapati Muni and the Maharshi Construct}

\section{Introduction}

Hagiographical literature on Ramana celebrates Ganapati Muni (1878-1936), a Telugu-speaking brahman Śaiva, as the one who first recognised Ramana's 'true greatness', and as his chief disciple. ${ }^{1}$ Prior to his association with Ramana, Ganapati Muni formed and led politically motivated societies comprised largely of students and religious disciples (see section 1.2.2). After Ganapati's decision to take Ramana as his guru, Ganapati's disciples also became Ramana's disciples, greatly increasing his following. From 1907 to the early 1930s, Ramana's following was therefore one he largely shared with Ganapati. As such, Ganapati always held a position of authority and influence in Ramana's ashram. Additionally, Ramana's attitude towards Ganapati was one of admiration and deep respect. ${ }^{2}$

In late 1907, Ganapati Muni approached Brahmana Swami (Ramana's name 1896-1907) on Arunachala with the desire to know the true nature of tapas (spiritual austerities/practice). Ramana responded as follows:

If one watches whence the notion 'I' arises, the mind is absorbed into That; that is tapas. When a mantra is repeated, if one watches the Source from which the mantra sound is produced the mind is absorbed in That; that is tapas. ${ }^{3}$

The hagiographical narrative holds that the originality of Brahmana Swami's response impressed Ganapati so immensely that he immediately recognised the young ascetic to be a living Maharshi (Great Vedic Seer). Ganapati deemed that Brahmana Swami should henceforth be known as 'Bhagavan Sri Ramana Maharshi'.

\footnotetext{
${ }^{1}$ B. V. Narasimha Swami, Self Realization: the Life and Teachings of Bhagavan Sri Ramana Maharshi (Tiruvannamalai: Sri Ramanasramam, 2007), 82-83; Osborne, Ramana Maharshi and the Path of Self-Knowledge, 103.

${ }^{2}$ Krishna Bhikshu, Sri Ramana Leela, trans. by Pingali Surya Sundaram (Tiruvannamalai: Sri Ramanasramam, 2003), 102-103. These points are expanded on in section 1.4.

${ }^{3}$ Osborne, Ramana Maharshi and the Path of Self-Knowledge, 103.

${ }^{4}$ Ibid., 104.
} 
In a bid to give appropriate impetus to this moment, hagiographical literature on Ramana portrays Ganapati as a brilliant Sanskrit scholar and poet, and as a spiritual adept who had performed years of intense tapas. Forsthoefel's brief treatment of Ganapati Muni follows the hagiographical narrative, merely describing him as a "brilliant Sanskrit pandit" (without qualifying it), who "insisted that the young guru be called Bhagavan Ramana Maharshi." ${ }^{\text {T }}$. M. P. Mahadevan described Ganapati as "a great Sanskrit scholar and savant," but also strictly limits his influence on Ramana to the creation of his name. ${ }^{6}$

What hagiographers omit, and Forsthoefel fails to discern, however, is the extent of Ganapati's political activities. These activities spanned three decades, and sought to expel the British from India and restore society to one based on Vedic principles. Key religious and political ideologies in the first decade of the twentieth century, such Vedic Aryanism, the rishi ideal and Indian nationalism, had therefore deeply influenced Ganapati.

Hagiographers also neglect to make an explicit connection between Ganapati's tapas and these very political objectives. ${ }^{7}$ Ganapati's tapas largely involved the practice of mantra japa (the repetition of sacred syllables), usually at an important pilgrimage site, and usually for long periods of time, such as two to three weeks. Ganapati's goal was to generate spiritual power, śakti, which he could then direct towards political pursuits (see section 1.2). As John Mitchiner explains, tapas is a "dynamically creative power, which enables the tapasvin or practitioner of tapas to change both himself and his environment."

This chapter argues that Ganapati's act of transforming Ramana - an ascetic Tamil Śaiva - into a Maharshi was motivated to serve his political agenda, which was informed by Vedic Aryanism and the rishi ideal, and concerned with India's liberation. Focusing on this point, I further argue that hagiographers of Ramana deliberately denied the political sphere in the Ramana narrative, which suggests that they were influenced by the Orientalist dichotomy of East (spiritual/rishi) and West (material/political ruler). Hagiographers such as B. V.

\footnotetext{
${ }^{5}$ Forsthoefel, Knowing Beyond Knowledge, 132.

${ }^{6}$ T. M. P. Mahadevan, Bhagavan Ramana (Tiruvannamalai: Sri Ramanasramam, 1989), 6.

${ }^{7}$ The connection between tapas (asceticism) and political objectives may also be seen in Gandhi's work for the national cause. See Lloyd I. Rudolf and Sussane Hoeber Rudolf, The Modernity of Tradition: Political Development in India (Chicago: The University of Chicago Press, 1967), 196199.

${ }^{8}$ John E. Mitchiner, Traditions of the Seven Rishis (Delhi: Motilal Banarsidass, 2000), 187.
} 
Narasimha Swami therefore considered that a purely spiritual, apolitical representation was required to legitimise Ramana's status as a rishi. To support these claims I structure the chapter as follows:

1. To complete the introduction I present a brief historical sketch that demonstrates the significance of Vedic Aryanism and the rishi ideal in the context of the colonial encounter. Further, I underline the role of Orientalist discourse in both of these themes.

2. I illustrate the contrasting representations of Ganapati Muni found in hagiographies of Ramana, on the one hand, and biographies of Ganapati, on the other. The former presents a selective portrayal aimed at preserving a purely spiritual representation of Ramana. The latter reveals a provocative and political depiction of Ganapati surprisingly not found in the former. Note, however, that biographies of Ganapati are still ultimately reverential.

3. I delineate the extent and continuity of Ganapati's political activities, underlining the periods immediately before and after 1907. This point indicates that he was highly preoccupied with politics at the time that he proclaimed Ramana to be a living Maharshi.

4. I disclose Ganapati's various conceptions of Ramana - for example, the Vedic rishi "emperor" of a future empire - all of which demonstrate that the role he intended Ramana to play was political.

5. I conclude with Ramana's highly positive attitude towards Ganapati and his ambitions, which indicates a willingness to participate in Ganapati's agenda. This point is further supported by evidence that Ramana symbolically and verbally endorsed Indian nationalism, which also, directly challenges Arvind Sharma's treatment of Ramana.

Apart from demonstrating that Ganapati's Maharshi construct was strongly connected to liberating India and restoring society to a Vedic-based system, the argument here is important due to claims presented in Chapter Two. At stake here is (1) the role the Maharshi symbol played in winning recognition and influence for Ramana from the 1930s onwards; (2) Ramana's construction as a living embodiment of Hindu truth to vindicate Hinduism and generate national pride; and (3) the ways in which the pan-Indian and orthodox nature of the Maharshi symbol allowed Hindu intellectuals such as S. Radhakrishnan and T. M. P. Mahadevan to construct Ramana as an Advaitin. 


\section{Historical background: Vedic Aryanism and the Rishi ideal}

During the colonial period, Hindu leaders frequently drew on religious ideals and symbols as part of their reform and political strategies. ${ }^{9}$ Ideologies such as that of a romanticised Vedic world, in which the rishi functioned as the ideal, therefore played a large role in the process of imagining a new national identity. This context influenced Ganapati Muni, who then projected the rishi ideal onto Ramana Maharshi as part of his political agenda.

The imagining of a romanticised society founded on ancient Vedic principles manifested as the so-called 'Golden Age' ideology. Vedic Aryanism, or the Golden Age ideology, emerged out of Orientalist discourse and assumptions about India's spirituality. ${ }^{10}$ Hindu reformers such as Dayananda Saraswati and Swami Vivekananda, as well as Gandhi, then harnessed these Orientalist assumptions and used them generate national pride as part of their anti-colonial projects. ${ }^{11}$ Importantly, Vedic Aryanism became the foundation and origin of a linear historico-ideology that nationalism would build upon. ${ }^{12}$ The influence of Vedic Aryanism may be calculated from the significant role it played in the agendas of Vivekananda, Keshab Chandra Sen, Bankim Chandra Chatterjee, Ranade, Tilak, Aurobindo, Annie Besant, Dayananda and Gandhi. ${ }^{13}$

Swami Vivekananda's (1863-1902) contribution to the construction of Hinduism as a world religion and the focus of national identity cannot be overstated. ${ }^{14}$ Vivekananda harnessed and utilised the Orientalist dichotomy of East and West and the popular imaginings of a Vedic Golden Age in his reformist agenda; ${ }^{15}$ the former best captured by his cry for India to "conquer the world with

\footnotetext{
${ }^{9}$ van der Veer, Religious Nationalism, 2; Chetan Bhatt, Hindu Nationalism: Origins, Ideologies and Modern Myths (Oxford: Berg, 2001), 2.

${ }^{10}$ S. Bandyopadhyay, From Plassey to Partition: a History of Modern India (New Delhi: Orient Longman, 2004), 246.

${ }^{11}$ Christophe Jaffrelot, The Hindu Nationalist Movement and Indian Politics: 1925 to the 1990s: Strategies of Identity Building, Implantation and Mobilisation (London: Hurst and Company, 1996), 16; van der Veer, Religious Nationalism, 56-57; King, Orientalism and Religion, 86, 134.

${ }^{12}$ Bhatt, Hindu Nationalism, 14.

${ }^{13}$ Ibid.

${ }^{14}$ Bandyopadhyay, From Plassey to Partition, 236; Tapan Raychaudhuri, "Swami Vivekananda's Construction of Hinduism", in Swami Vivekananda and the Modernization of Hinduism, ed. William Radice (New York: Oxford University Press, 1998), 1.

${ }^{15}$ Swami Vivekananda, Selections from Swami Vivekananda (Calcutta: Advaita Ashram, 1963), 497-98.
} 
her spirituality", ${ }^{16}$ with the latter continually manifesting in his speeches and writings as the rishi ideal.

Vivekananda repeatedly emphasised the glory of the ancient rishis, often exhorting his audience to realise the spiritual state of a rishi. ${ }^{17}$ Lecturing in Chicago (1893) on the laws contained in the Vedas, Vivekananda declared: "The discoverers of these laws are called Rishis, and we honour them as perfect beings." 18 On another occasion, Vivekananda proclaimed: "When you have known God your very face will be changed...This is the Rishihood, the ideal of our religion." 19

Vivekananda described the rishi as "the pure one", ${ }^{20}$ whose "state is not limited by time or place, by sex or race. ${ }^{21}$ Vivekananda conceived of the rishi as purely spiritual, timeless and otherworldly, and in a way that differed from traditional accounts of the rishis, in which they also played important social, political and worldly roles. ${ }^{22}$ Thus, we see evidence of the Orientalist dichotomy of East and West informing Vivekananda's thinking, which in turn influenced hagiographers of Ramana, who denied the political sphere in their portrayals of Ramana and Ganapati Muni. Furthermore, Vedic Aryanism and the rishi ideal profoundly influenced Ganapati Muni and dominated his political thinking. In 1907, Ganapati constructed Ramana according to these key themes.

\footnotetext{
${ }^{16}$ Swami Vivekananda, The Collected Works of Swami Vivekananda, vol., III (Calcutta: Advaita Ashrama, 1964), 277.

${ }^{17}$ Vivekananda, Selections from Swami Vivekananda, 497-98; Rajagopal Chattopadhyaya, Swami Vivekananda in India: A Corrective Biography (Delhi, Motilal Banarsidass, 1999), 230.

${ }^{18}$ Vivekananda, Selections from Swami Vivekananda, 5. Taken from his speech at the World's Parliament of Religions, Chicago, 1893.

${ }^{19}$ Ibid., 298-99. The rishi ideal may even be seen in Gandhi's writing. In Hind Swaraj, Gandhi emphasised the status of the rishis, praising their ethics and religiosity, and noting that their position was superior to the ruling sovereigns. See M. K. Gandhi, "Hind Swaraj," in Sources of Indian Tradition, vol. II, ed. and revised by Stephen N. Hay (New York: Columbia University Press, 1988), 255.

${ }^{20}$ Vivekananda, Selections from Swami Vivekananda, 217.

${ }^{21}$ Ibid., 297.

${ }^{22}$ Mitchiner, Traditions of the Seven Rishis, 218-225.
} 


\subsection{Ganapati Muni: Sanskrit scholar, poet and spiritual adept}

This section examines representations of Ganapati Muni in major hagiographies on Ramana, including B. V. Narasimha Swami's Self Realization, Arthur Osborne's Ramana Maharshi and the Path to Self-Knowledge and Krishna Bhikshu's Sri Ramana Leela. ${ }^{23}$ These works present a selective and watered-down version of Ganapati, avoiding explicit and detailed reference to his political life. They emphasise a Sanskrit scholar, poet, and spiritual adept dedicated to tapas, the latter offering a seamless transition into the proclamation of Ramana as a Maharshi in 1907. I argue that the failure to expose Ganapati's political activities rests on the desire to preserve a purely spiritual representation of Ramana, and thus not risk contention of Ramana's rightful status as a rishi. This section therefore represents the first of several steps in which I argue that hagiographers of Ramana followed the Orientalist dichotomy of East and West, i.e. that the spiritual must remain separate and distinct from the material and political.

B. V. Narasimha Swami was a lawyer and Congressman from Tamil Nadu. He resided at Sri Ramanasramam (Ramana's ashram) from 1929 until 1931, during which time he researched and composed Self Realization. Narasimha also translated the life and sayings of Vivekananda into Tamil during the same period, ${ }^{24}$ which suggests that Narasimha had been significantly influenced by Vivekananda, and importantly, his emphasis on the rishi ideal and the ways in which it conformed to the Orientalist dichotomy of East and West.

Narasimha's treatment of Ganapati Muni exclusively emphasised his literary abilities and tapas. Narasimha claimed that Ganapati could speak and write Sanskrit "with ease" by the age of fourteen, having already become familiar with the Rāmāyana, the Mahābhārata and other important texts. ${ }^{25}$ Narasimha stated that the "the main item" of Ganapati's life entailed the "adventures of his tapas", declaring that its purpose was to obtain a vision of Śiva, who would then

${ }^{23}$ B. V. Narasimha Swami, Self Realization: the Life and Teachings of Bhagavan Sri Ramana Maharshi (Tiruvannamalai: Sri Ramanasramam, 2007). This work was the first biography of Ramana. It was first published in 1931 and written in English. Current president of Sri Ramanasramam, V. S. Ramanan, stresses in his 'Publisher's Note' that all subsequent biographical accounts are strongly based upon this original work. See ibid., iv. This book therefore serves as the 'master narrative'. Arthur Osborne, Ramana Maharshi and the Path of Self-Knowledge (London: Rider and Company, 1970); Krishna Bhikshu, Sri Ramana Leela, trans. by Pingali Surya Sundaram (Tiruvannamalai: Sri Ramanasramam, 2003).

${ }^{24}$ Narasimha Swami, Self Realization, 204.

${ }^{25}$ Ibid., 82-83. 
"grant him boons." ${ }^{26}$ Narasimha neglected, however, to elaborate on the specific "boons" Ganapati had in mind, which we see below clearly relate to political objectives.

In between his description of Ganapati's literary achievements and the Maharshi proclamation of 1907, Narasimha only briefly alluded to what he calls Ganapati's "lofty mission in life," which he described fleetingly as the "resuscitation" of Vedic ideals for the advancement of an impoverished Indian society. ${ }^{27}$ Ganapati's political activities and his participation in Congress were blatantly ignored. This point is interesting because Narasimha himself was a Congressman and "ardent participant in the liberation struggle." 28

Narasimha further downplayed Ganapati's political activities by employing a generalising and universalising rhetoric. For example, Narasimha noted that Ganapati had gathered a "band of pupils" who aimed at working towards "the uplift of the country, if not humanity." 29 As we see below, Ganapati founded political societies aimed precisely at liberating India and establishing a society based on Vedic ideologies. Hence, there appears to be a deliberate effort not to detract from the purely spiritual presentation of the Ramana narrative.

Arthur Osborne's hagiography, arguably the most popular work on Ramana since its publication in 1954, closely followed Narasimha's presentation of Ganapati Muni. Osborne (1907-1970) was educated at Oxford and taught English at a university in Bangkok. He came to permanently reside at Sri Ramanasramam in 1945 as a devotee of Ramana, and continued to work closely with the ashram until his death in 1970, editing and producing several works on his guru. ${ }^{30}$

Osborne emphasised (1) Ganapati's standing as an eminent Sanskrit scholar; (2) his proclamation that Brahmana Swami was 'Bhagavan Sri Ramana Maharshi'; and (3) his composition of the Śri Ramana Gìta.$^{31}$ Like Narasimha, Osborne confined his description of Ganapati's aspirations to a generalised and universalised scope, neglecting his political activities. Following Narasimha,

\footnotetext{
${ }^{26}$ Ibid., 83.

${ }^{27}$ Ibid., 90

${ }^{28}$ V. S. Ramanan, "Publisher's Note," in Self Realization: the Life and Teachings of Bhagavan Sri Ramana Maharshi (Tiruvannamalai: Sri Ramanasramam, 2007), iii.

${ }^{29}$ Ibid., 86.

${ }^{30}$ Narain, ed., Face to Face with Sri Ramana Maharshi, 94-95.

${ }^{31}$ Osborne, Ramana Maharshi and the Path of Self-Knowledge, 102-06.
} 
Osborne carefully used "uplift" to describe Ganapati's objectives, applying it either to "mankind" or "the whole nation". ${ }^{32}$ As we see below, it is more accurate to describe Ganapati's goal as to liberate India from British oppression, rather than "uplift mankind".

Osborne continued describing Ganapati's ambitions in diluted and generalised tones, as "the regeneration of the country, the revitalisation of religion." 33 Even such vague references to his political activities were greatly outweighed by those to his scholarly, poetic and spiritual attributes. For example, Osborne claimed that Ganapati's "towering ability" "would have placed him in the very forefront of modern writers and scholars." 34 Overall, Osborne's treatment avoided an explicitly politicised rhetoric. Further, he ignored Ganapati's involvement in Congress politics and his ambition of rebuilding Indian society on a Vedic model. In doing so, Osborne successfully preserved a purely spiritual representation of Ganapati, and importantly, of the Ramana narrative.

Compared to Narasimha and Osborne, Krishna Bhikshu's treatment of Ganapati Muni in Sri Ramana Leela makes important admissions of Ganapati's political ambitions, though they are brief and outweighed by reference to spiritual and literary achievements. ${ }^{35}$ Bhikshu's account was also more extensive, allotting ten pages to Ganapati's role in Ramana's life, compared to Osborne's four pages, for example. The more detailed account is likely dependent on their shared Telugu identity. Bhikshu emphasised Ganapati's literary achievements and Sanskrit dexterity, highlighting his acquisition of the honorary prefix 'Kavyakantha' (one who has poetry in his throat) at an official congregation of renowned scholars at Nawadwipa when "he was barely twenty-two.",36

Bhikshu also stressed Ganapati's intense preoccupation with tapas, and like Narasimha, referred to Ganapati's motivation as the desire to have darśan of Śiva. Unlike Narasimha and Osborne, Bhikshu connected Ganapati's tapas to the desire to restore Indian society to a "glorious Aryan civilisation," and in so doing, he moves closer towards a more accurate account. ${ }^{37}$ However, this provocative

\footnotetext{
${ }^{32}$ Ibid., 101-03.

${ }^{33}$ Ibid., 105.

${ }^{34}$ Ibid., 102.

${ }^{35}$ A Telugu biography of Ramana, first published in 1936. An English translation was published in 2003.

${ }^{36}$ Bhikshu, Sri Ramana Leela, 95.

37 Ibid., 96.
} 
revelation was not associated with colonial oppression and the liberation movement, but instead to a "vision" that resulted from the study of Vedic literature. ${ }^{38}$ Thus, Bhikshu maintained the emphasis on Ganapati's scholarly aptitude. Towards the end of his treatment, Bhikshu let slip one brief statement more directly addressing politics, admitting that Ganapati "participated in politics and social reform activities till 1930." 39 There was no elaboration on these activities, however, and as in Narasimha and Osborne, no mention of his participation in Congress during the 1920s.

Bhikshu's treatment, in particular, raises the issue of originality in the teaching Ramana imparted to Ganapati on the nature of tapas (see above), a teaching which conforms strongly to Ramana's typical 'Self-enquiry' (Ätma Vicāra) teaching. ${ }^{40}$ According to Bhikshu, Ganapati "recognised that...a new path for attaining moksha" was revealed in Ramana's response, continuing that "nobody else had discovered this path earlier." ${ }^{41}$ This supposed originality therefore largely influenced Ganapati's conviction that Ramana was a living rishi.

However, Lakshmana Swamy, a devotee of Ramana, provides evidence to the contrary: "The teaching of self-enquiry is not a new one. The sage Vasishtha taught it to Rama in the Yoga Vasishtha, but most people had forgotten about this." 42

This argues against any claim to originality, and finds further support from Masthan, a Muslim devotee of Ramana. Masthan professed that he became attracted to Ramana after hearing his teaching, which he had already come across in several different sources. Masthan stated that Ramana gave the following reply to his request to know nirguna (formless) meditation: "Fix the mind in the heart. If you keep your attention at the source from where all thoughts arise then the mind will subside at the source and that which is will shine forth." This reply closely corresponds to the one Ramana gave Ganapati in 1907. Masthan further stated that he had already come across this teaching in the text Mahārāja Turavu,

\footnotetext{
38 Ibid.

${ }^{39}$ Ibid., 103.

40 Atma Vichara, or 'Self-enquiry', is Ramana's primary 'verbal' teaching. Put succinctly, Ramana's advises the aspirant to seek the source from which the 'I' or the ego arises, recommending the inquiry 'Who am I?' to realise that source.

${ }^{41}$ Bhikshu, Sri Ramana Leela, 98.

${ }^{42}$ David Godman, No Mind - I am the Self: The Lives and Teaching of Sri Lakshmana Swamy and Mathru Sri Sarada (Nellore: Sri Lakshmana Ashram, 2005), 92.
} 
in verses by a Tamil Muslim saint known as Gunangudi Masthan, and in Śankara's hymns. He claimed that he had also read the same in many other books. ${ }^{43}$ If this is the case, then Ganapati, a 'Sanskrit scholar' who "had read all there is to read," would certainly have encountered the teaching Ramana presented him in 1907. Hence, the unoriginal status of Ramana's teaching further points to political motives behind Ganapati's construction of Ramana as a Maharshi.

In sum, the emphasis seen in the three accounts on Ganapati's tapas facilitated a fluid transition to the event in which Ganapati constructed Ramana as a Maharshi. There is a more general connection between tapas and rishis, in that the rishis are regarded as authorities and experts on tapas. ${ }^{44}$ In fact, Mitchiner observes: "The very meaning of the word tapas is itself closely connected in many respects with the meaning of the term rishi." ${ }^{45}$ These authors present Ganapati's tapas as motivated by spiritual and humanitarian objectives. I argue that this strategy was deliberate and aimed at keeping the Ramana narrative untainted by worldly 'impurities', such as colonialism, politics and the liberation struggle. In other words, there was a calculated attempt to deracinate Ramana from anything that is not entirely spiritual, otherworldly and divine. In a more narrow sense, the strategy to conceal Ganapati's political activities and present them in a generalised, spiritual and humanitarian context staves off potential suspicions about his motives. The process of a disciple giving a new title to his guru is already unorthodox and contentious - ordinarily it is the guru who presents the disciple with a new name. Hence, any further information that might give rise to suspicion would ultimately detract from an otherwise momentous and celebrated event in the Ramana narrative.

\subsection{The radical freedom fighter: political representations of Ganapati Muni}

As far as I could discover, there are currently three biographies of Ganapati Muni: Kapali Sastry’s Sanskrit Vaśiștha Vaibhavam; ${ }^{46}$ Gunturu Lakshmikantam’s

\footnotetext{
${ }^{43}$ Arunachala's Ramana, vol. I, 274-75.

${ }^{44}$ Mitchiner, Traditions of the Seven Rishis, xv.

${ }^{45}$ Ibid., 187.

${ }^{46}$ T. V. Kapali Sastry, Collected Works of T. V. Kapali Sastry, vol. VII (Pondicherry: Dipti Publications, 1983).
} 
Nayana: Kavyakantha Vasistha Ganapati Muni; ${ }^{47}$ and A. V. Ramana's Maha Tapasvi: The Life Story of Kavyakantha Ganapati Muni. ${ }^{48}$ Lakshmikantam and Sastry were both disciples of Ganapati, while A. V. Ramana is Ganapati's grandson. The latter two works, though originally written in Telugu, have been translated into English, and thus provide the main sources for this section. These biographies, while still reverential, clearly present Ganapati as a radical freedom fighter, whose foremost concern was to liberate India and restore Indian society to one based on Vedic principles. They also directly connect the motives behind his tapas to achieving these political objectives. This representation therefore supports the claim that Ganapati's construction of Ramana as a Maharshi was motivated to serve his own political agenda. It further shows that hagiographers of Ramana purposely denied the political sphere in their portrayals of Ramana in order to legitimise his lofty status as a rishi.

A. V. Ramana stated that Ganapati believed India's domination by the British had resulted from the spiritual degeneration of his country, emphasising that Ganapati saw the Vedic period with its rishis as India's most spiritually glorious age. To Ganapati, the return to a Vedic way of life with rishi leaders would therefore expel foreign oppressors. ${ }^{49}$ A. V. Ramana stated that Ganapati's "goal was to free the country and to restore Vedic culture to India." ${ }^{50} \mathrm{~A}$. V. Ramana included one of Ganapati's compositions, Indrani Saptasati, which clearly expressed his desire to liberate India: "O Mother! Please bestow strength on me so that I may save Bharat Bhoomi, my country, which is divided into thousands of parties and is in great distress due to the burden of enemy." 51 Such candour is not found in hagiographies of Ramana surveyed above.

Like the hagiographies of Ramana, A. V. Ramana strongly emphasised Ganapati Muni's intense preoccupation with tapas. However, here we see a directly politicised account of its motives:

Tapas is usually undertaken with a desire for liberation [i.e. spiritual liberation, moksha]. But Ganapati said that he did not

\footnotetext{
${ }^{47}$ Gunturu Lakshmikantam, Nayana: Kavyakantha Vasistha Ganapati Muni, trans. by Dr G. Krishna (Hyderabad: Raghavendra Graphics, 1978).

${ }^{48}$ A. V. Ramana, Maha Tapasvi: The Life Story of Kavyakantha Ganapati Muni, trans. by Sonti Anasuyamma (Tiruvannamalai: Sri Ramanasramam, 2009).

${ }^{49}$ Ibid., 120.

${ }^{50}$ Ibid., 223.

${ }^{51}$ Ibid.
} 
desire liberation. His sole prayer was the well-being and liberation of his country. From his childhood Ganapati's sole aim was to see his country liberated from foreign rule. The tapas he did was for this end. ${ }^{52}$

A. V. Ramana clearly disconnected the goal of Ganapati's tapas from the more orthodox and spiritual pursuit of moksha, and firmly connected it to India's independence from British rule, which he described as Ganapati's sole concern. The strategy of using spiritual superiority to defeat the British had emerged in Gandhi and Aurobindo, and can be traced back to Vivekananda, who commanded: "Up, India, and conquer the world with your spirituality." ${ }^{, 53}$ Ganapati therefore appears to have participated in this trend.

In equally politicised language, Lakshmikantam echoed A. V. Ramana's assertion that the motives behind Ganapati's tapas concerned liberating India. Lakshmikantam's work underlined Ganapati's passion for travelling to important pilgrimage sites throughout India to engage in intense austerities. In the midst of these descriptions, Lakshmikantam affirmed tapas as Ganapati's "method for accomplishing his object for the redemption of the Motherland." ${ }^{54}$ In another example, Lakshmikantam stressed that Ganapati's "students and admirers" clearly discerned "that his tapas was intended to earn divine grace for the complete emancipation of the Motherland." 55 Lakshmikantam directly connected Ganapati's tapas with the desire for India's political liberation.

A. V. Ramana and Lakshmikantam therefore portrayed Ganapati's spiritual practice as motivated only by politics. Their politicised descriptions confirm that Narasimha and Osborne's use of "uplift the nation, if not humanity" was meant to generalise, universalise and downplay Ganapati's political activities.

Natesan, M. S. Kamath and T. K. Sundaresa Iyer have offered further evidence that political objectives motivated Ganapati's tapas. Little is known about Natesan other than that he was a devotee of both Ramana and Ganapati Muni. Natesan described Ganapati as a "patriot and political thinker," 56 who harboured a "burning patriotism."

52 Ibid., 42.

${ }^{53}$ Vivekananda, The Collected Works of Swami Vivekananda, vol, III, 277.

${ }^{54}$ Lakshmikantam, Nayana, 88.

55 Ibid., 65.

${ }^{56}$ Natesan, "Kavyakantha,” in Ramana Smrti (Tiruvannamalai: Sri Ramanasramam, 1980), 111.

${ }^{57}$ Ibid., 113. 
India's political status was more immediate and important than individual pursuits. He affirmed that Ganapati held the "strong conviction...that national welfare should be placed above individual salvation." 58 Natesan further stated that Ganapati was "a firm believer in mantra japa (i.e. tapas) and its power to solve all problems, including that of Indian Independence." 59 Again, we see a highly politicised representation of Ganapati, in which his tapas is firmly associated with India's liberation from British occupation.

In the early 1930s, the editor of the Sunday Times (Madras), M. S. Kamath, published a series of pamphlets of political propaganda under the title My Motherland. ${ }^{60}$ In pamphlet two, "Sri Ramanasramam: With a Life Sketch of the Maharshi”, Kamath described Ganapati Muni as one of the devotees "known to the wider public," and as "a most brilliant personality." ${ }^{61}$ However, in the context of the My Motherland series, Kamath found it appropriate to disclose Ganapati's political involvement. He revealed: "Strange though it may seem, he has been a most radical social reformer and an ardent patriot - with a devouring passion for the all round liberation of the Motherland, preferably through spiritual means." 62 Thus, Kamath connected the goal of liberating India with spiritual practice, i.e. tapas, and depicted Ganapati as a "radical" and "ardent patriot".

Like Natesan, T. K. Sundaresa Iyer was also a devotee of both Ganapati and Ramana, studying the Vedas under the former for eight years. ${ }^{63}$ Iyer stated that he was appointed General Secretary of Ganapati's 'Mahendra Societies', which were established across India. He declared: “Their object was to win freedom for our country by purely devotional means, like rituals, prayers, and personal and collective penance. We managed to register about ten thousand members." ${ }^{64}$ Without directly using the word tapas, Iyer inferred that Ganapati and his followers adopted spiritual practice as the principal strategy to achieve

\footnotetext{
58 Ibid., 111.

${ }^{59}$ Ibid. Mantra japa refers to the repetition of sacred syllables and the name/s of gods.

${ }^{60}$ This work was encountered during my research in the archives at Sri Ramanasramam during August-September 2010.

${ }^{61}$ M. S. Kamath, My Motherland (Madras: The Sunday Times, Office), 8.

${ }^{62}$ Ibid. Italics mine.

${ }^{63}$ T. K. Sundaresa Iyer, At the Feet of Bhagavan (Tiruvannamalai: Sri Ramanasramam, 2005), 17.

${ }^{64}$ Ibid. Italics mine. Krishnamurthi Iyer, friend of T. K. Sundaresa Iyer, highlights Ganapati Muni's political ambitions as follows: "T. K. S. Told me how, with himself as secretary, Ganapati Muni had organised a Mahendra Sangha with about ten thousand members all over India to perform japas, homas and diverse spiritual practices for the emancipation of India from the foreign yoke." Arunachala's Ramana, vol. II, 61.
} 
political liberation. He also touched on Ganapati's establishment of large political societies - a point blatantly overlooked in hagiographies of Ramana.

In sum, the representations of Ganapati Muni in A. V. Ramana, Lakshmikantam, Kamath, Natesan and Iyer portrayed a figure whose sole preoccupation was liberating India and restoring society to one based on Vedic principles. Further, they deemed that the primary motive of Ganapati's tapas asserted by Narasimha to be "the main item" of his life - was precisely to achieve these political goals. This politicised portrayal of Ganapati affirms that his construction of Ramana as a Maharshi was motivated to serve his own political agenda.

\subsection{Persistent activist and Congress member}

This section supports my claim that Ramana's status as a Maharshi depended upon the political agenda of Ganapati Muni, by illustrating Ganapati's ongoing political activities, which lasted from 1904 until at least the late 1920s. I highlight Ganapati's preoccupation with political activities immediately prior to and after the event in which he lauded Brahmana Swami as Bhagavan Sri Ramana Maharshi. I also stress his service as a Congress member in the 1920s, a point strikingly absent from representations of Ganapati in hagiographies of Ramana.

Ganapati had actually first encountered Ramana in 1903. Interestingly, Ganapati only saw Ramana twice in that year. If Ganapati had "immediately discerned the greatness and state of the young sage," 65 as claimed in hagiographies, why did he not proclaim Ramana to be a Maharshi in 1903, when he first encountered him? Moreover, why did he only visit Ramana twice in 1903, and then not again until 1907? These points clearly stand in tension with the claim that Ganapati immediately recognised Ramana's apparent true greatness, and demand further inquiry into potential ulterior motives behind his construction of Ramana as a Maharshi.

Ganapati's participation in the liberation movement began when he attended gatherings held in Madras from early 1904. During these gatherings Ganapati delivered speeches about the rishi culture of Vedic times and the current

${ }^{65}$ Arunachala's Ramana, vol. I, x. Italics mine. 
condition of society under British rule. ${ }^{66}$ A. V. Ramana and Lakshmikantam both described 1904 as a period during which Ganapati inspired certain people within education and political circles in Madras to fight against British rule, and also one during which he acquired followers, who were mainly students. ${ }^{67}$ Lakshmikantam asserted that Ganapati passionately urged these students to desire India's liberation. ${ }^{68}$

At the end of 1904, Ganapati moved to Vellore after acquiring the post of Telugu pandit at the Vellore Christian College. Hagiographers of Ramana like Osborne, include this event, but conceal the following information: Ganapati used this position to lecture on the glory of Vedic civilisation and "chastise" the British Christian attitude. ${ }^{69}$ During this period Ganapati formed and led a politically oriented society called the 'Indra Sena', comprised of forty students. Two of the fundamental principles of the Indra Sena were: (1) "The British have no authority to strangle the beliefs of the Indians"; and (2) "Vedic knowledge must be inculcated in Indian minds". ${ }^{70}$ These politically oriented activities earned Ganapati the attention of the British, who placed him under surveillance. ${ }^{71}$

In November 1907, Ganapati returned to Tiruvannamalai. After a four year interval preoccupied with political activities, Ganapati approached Ramana for a third time. It was only on this occasion that Ganapati finally transformed an ascetic Tamil Śaiva into a pan-Indian Vedic symbol, by means of his construction of Brahmana Swami as a Maharshi. He also accepted Ramana as his guru and sent a letter to Vellore to notify his family and followers of the news. Several days later, Ganapati's wife and "a number" of his disciples arrived from Vellore. ${ }^{72}$

At this point Ramana had been residing at Arunachala for eleven years. Although he had acquired a mostly positive reputation in Tiruvannamalai itself, Ramana's devotees were very few, and Palani Swami was his only permanent attendant. This moment therefore marks the beginning of a significant increase in the number of followers attached to Ramana. It is significant that these followers

\footnotetext{
${ }^{66}$ Ramana, Maha Tapasvi, 121

${ }^{67}$ Ibid., 122-24; Lakshmikantam, Nayana, 62

${ }^{68}$ Lakshmikantam, Nayana, 63.

${ }^{69}$ Ramana, Maha Tapasvi, 131.

70 Ibid.

${ }^{71}$ Ibid., 129.

${ }^{72}$ Lakshmikantam, Nayana, 82.
} 
arrived through Ganapati, and hence were deeply concerned with the nationalist program.

Another wave of Ganapati's devotees soon arrived in Tiruvannamalai for the occasion of Ganapati's recital of Uma Sahasram, a thousand verse poem dedicated to the Goddess, composed to celebrate the occasion of Ganapati's 'discovery' of a living rishi. ${ }^{73}$ An examination of this work reveals that political liberation was firmly established in Ganapati's thinking during this period. According to A. V. Ramana, Ganapati believed that "the mantras, tantras and philosophical contents" in Uma Sahasram were to be understood as "the weapons of war." ${ }^{74} \mathrm{He}$ affirmed that Ganapati "composed many verses in Uma Sahasram invoking the grace of Uma to free his country from slavery." 75 The following exemplifies this point: "O Mother Parvati! Bestow good thoughts on our people. Save our Bharata clan which has become destitute. Give me, who am thy devotee since long, this boon." 76 In another example, Ganapati declared: "O Mother! Give me the power to save the land of Bharat."77

It is thus evident that Ganapati's concern for India's independence dominated his thoughts immediately prior to and following his construction of Ramana as a Maharshi. India's liberation was still the sole concern in the months immediately following. As A. V. Ramana pointed out, in early 1908, Ganapati "still had the freedom of his country at heart.",78

From 1908 until 1920, Ganapati’s activities largely involved travelling throughout India, spreading word of the living rishi that he had discovered. ${ }^{79}$ During this period, Ganapati typically incited his audience to "stand up against the onslaughts of the Motherland and religion." ${ }^{80}$ Ganapati's travels mostly targeted important pilgrimage centres and religious institutions, such as Gokarna,

\footnotetext{
${ }^{73}$ Ibid., 86. Unfortunately, there is no entire English translation of Uma Sahasram with which to work, meaning I have had to rely on excerpts supplied in biographies of Ganapati Muni.

${ }_{75}^{74}$ Ramana, Maha Tapasvi, 182.

75 Ibid., 179.

${ }^{76}$ Ibid., 135.

${ }^{77}$ Ibid., 154.

${ }^{78}$ Ibid., 164.

${ }^{79}$ Lakshmikantam, Nayana, 92-147.

${ }^{80}$ Ibid., 125.
} 
Varanasi, Gaya and Ayodhya, ${ }^{81}$ but he also spent time in major political centres such as Madras (1908; 1910-12) and Secunderabad (1913). ${ }^{82}$

According to T. K. Sundaresa Iyer, Ganapati's career with Congress began when he became the president of the Tiruvannamalai town Congress Committee around 1920. ${ }^{83}$ In 1923, Ganapati became a Congress member after he accepted an invitation from the Indian National Congress to attend the Kakinada session. He had previously attended a Congress session in 1916. According to Lakshmikantam, during the Kakinada session, Ganapati argued in favour of resuscitating "the way of the rishis for the restoration of society." 84 Lakshmikantam claimed that following this session, "many Congressmen (from Andhra Pradesh) wished that Ganapati Muni would help their cause by accepting political leadership." 85 Although he rejected their appeal, in 1924 he became a member of the Tamil Nadu Congress and was elected Chairman of the reception committee of the Tamil Nadu Congress conference held that year in Tiruvannamalai. According to A. V. Ramana, Ganapati delivered the inaugural speech at this session, at which both Gandhi and Annie Besant were present. ${ }^{86}$

Ganapati next participated in the December 1924 Belgaum Congress session, which was presided over by Gandhi. Lakshmikantam and A. V. Ramana both stated that Ganapati used this session to propose Sanskrit as India's national language. They both hold that Gandhi rejected Ganapati's movement, and instead nominated Hindi as the most suitable choice. ${ }^{87}$ According to Lakshmikantam, Ganapati did not renew his Congress membership after the Belgaum Session. ${ }^{88}$ A. V. Ramana maintained, however, that Ganapati attended Congress sessions in 1927, such as the one in Hyderabad. ${ }^{89}$ These points demonstrate that Ganapati participated in the liberation struggle until at least the latter half of the 1920s, and further, that the agenda he promoted centred on Vedic principles that included the rishi ideal.

\footnotetext{
${ }^{81}$ Ibid., 110-129.

${ }^{82}$ Ibid., 92; 115-120; 125.

${ }^{83}$ Iyer, At the Feet of Bhagavan, 5.

${ }^{84}$ Lakshmikantam, Nayana, 147.

${ }^{85}$ Ibid., 148.

${ }^{86}$ Ramana, Maha Tapasvi, 245.

${ }^{87}$ Ibid., 35 and 245. Lakshmikantam, Nayana, 149.

${ }^{88}$ Lakshmikantam, Nayana, 149.

${ }^{89}$ Ramana, Maha Tapasvi, 246.
} 
In sum, Ganapati Muni was actively involved in attempting to liberate India and restore society to one based on Vedic ideologies from 1904, and importantly, immediately prior to and after his proclamation of Brahmana Swami as Bhagavan Sri Ramana Maharshi. Ganapati's political activities continued into the 1920s, during which period he served as a Congress member, promoting "the way of the rishis". This evidence strongly supports the claim that his political agenda determined his construction of Ramana as a Maharshi, and further, that hagiographers of Ramana deliberately omitted the details of Ganapati's political activities in order to construct a purely spiritual Ramana narrative, which would legitimise his status as a rishi.

\subsection{Ganapati's mission and Ramana as the Rishi Vedic Emperor}

This section expands on the details of Ganapati Muni's political agenda by focusing on (1) his self-appointed mission and duty to liberate India; (2) his deified conception of himself as Ganeśa incarnate; and most importantly (3) the role he expected Ramana and Arunachala to play in his political mission, the former as rishi emperor, and the latter as the capital of a future empire. This section also addresses Ganapati's additional conceptions of Ramana as Skanda, the god of war, and as an incarnation of Campantar, a Tamil Śaiva saint. All of this indicates that Ramana was closely bound up with Ganapati's political vision of liberating India and restoring society to a Vedic system.

There is sufficient evidence in Ganapati's compositions and the accounts of his associates that he believed that he had an important, if not divine, role to play for his country. A. V. Ramana asserted that Ganapati believed it was his duty both to liberate India, and to return it to its past Vedic glory. ${ }^{90}$ Following Narasimha's line that Ganapati had a "lofty mission,"91 Balarama Reddy stated that Ganapati "believed he was born on earth for a mission," which he described as "to rejuvenate India through mantra japa." 92 From evidence already surveyed we can infer here that "rejuvenation" meant political liberation. Reddy clearly revealed Ganapati's conviction that he had an important role to play for India.

\footnotetext{
${ }^{90}$ Ibid., 129.

${ }^{91}$ See above.

92 N. Balarama Reddy, My Reminiscences (Tiruvannamalai: Sri Ramanasramam, 2008), 55.
} 
Further, Ganapati's conceptions of Ramana are also strongly connected to his political mission. In fact, Lakshmikantam asserted that Ganapati was convinced that Ramana had chosen him to be his voice. ${ }^{93}$ In Ganapati's last surviving letter to Ramana, dated 15 November 1931, he requested Ramana to offer his grace, pleading that he "should not forsake one whose mission is the same as His (Ramana's)." 94 Ganapati concluded the letter as follows: "May Bhagavan impel this follower to prepare the ground for the mission for which Bhagavan has incarnated." 95 The mission implied was the political liberation of India, and further, Ganapati clearly held Ramana to be a divine gift sent to achieve this mission.

Ganapati certainly deemed his mission divinely ordained, and himself a divine figure. At the conclusion of a śloka he composed in front of Ramana and his attendant Palani Swami, Ganapati hailed himself as "the Son of God."96 Ganapati believed himself to be an incarnation of his namesake, also known as Gaṇeśa, the elephant-headed first son of Śiva, and the god of wisdom and remover of obstacles.

In addition to himself as Gaṇeśa incarnate, Ganapati believed that Ramana was not only a Maharshi, but also an incarnation of Śiva's second son, Skanda, the god of war. ${ }^{97}$ In his compositions, Ganapati portrayed Ramana as Skanda using alternate names such as Karthikeya, Subramania, and Guha. ${ }^{98}$ In the context of Ganapati's ambitions, his conception of Ramana as the god of war is indicative of the political role he wanted Ramana to play. The following passage from Uma Sahasram exemplifies Ganapati's conception of himself and Ramana as the sons of Śiva during British occupation: “O Mother! Please tell me why you have made your own sons, Brihaspati and Agni, be born as Ganapati and Guha in this land Bharata, in these tumultuous times." 99 Notably, Ganapati initially mentioned two Vedic gods, i.e. Brihaspati and Agni, highlighting the Vedicism in his thinking. According to Ganapati, these gods had manifested as Siva's sons,

\footnotetext{
${ }^{93}$ Lakshmikantam, Nayana, 125.

${ }^{94}$ Vasishtha Ganapati Muni, Epistles of Light: Letters from Vasishtha Kavyakantha Ganapati Muni to Bhagavan Sri Ramana Maharshi (Tiruvannamalai: Sri Ramanasramam, 2006), 59.

${ }^{95}$ Ibid., 59-60.

${ }^{96}$ Lakshmikantam, Nayana, 135.

${ }^{97}$ Bhikshu, Sri Ramana Leela, 308-12.

${ }^{98}$ Muni, Epistles of Light, 3.

${ }^{99}$ Ramana, Maha Tapasvi, 10.
} 
Ganapati (Ganapati Muni) and Guha (Ramana). These points affirm that Ganapati believed that he had a divinely sanctioned political mission to fulfil, which he was to achieve in alliance with Ramana.

The political role Ganapati intended Ramana to play is supported by a third, and more sectarian, conception. In this instance, Ganapati constructed Ramana as an incarnation of Campantar, one of the most important saints in the Tamil Śaiva tradition. ${ }^{100}$ Campantar is recorded in the Periya Purānam (a hagiography of 63 Tamil Śaiva saints) as the Śaiva bhakta who defeated the 'heterodox' Jains and Buddhists in Tamil Nadu. In doing so, Campantar restored dharma, i.e. the rightful order of things, to Tamil society. ${ }^{101}$ Therefore, Ganapati viewed the purpose of Ramana's present incarnation, though in a different context, as achieving the same goal - defeat the British and restore dharma to Indian society.

Ganapati's references to the birth of Ramana are highly revealing. Ganapati begins: "Whenever the world suffers from the dominance of unrighteousness, great souls are born who uplift the world by their presence." 102 The 'world' here signifies India, and the dominance of unrighteousness is arguably the presence of the British. Ganapati carried on celebrating Ramana by adding him to a list which included Rāma, Kṛ̣ṇa, the Buddha and Śankkarācārya, all of whom had "wonderful powers, though they wielded neither the bow nor the sword." 103 Ganapati concluded: "What a hero could not achieve by the sword, they achieved by their soul force." ${ }^{104}$ His use of "soul force' follows Gandhian rhetoric, and evokes a context closely related to the struggle for swaraj.

Ganapati's following verse on Ramana's birth clearly supports this claim. He describes Ramana as "a yogi of such great qualities" that he was born to "purify" his country and "adorn 'Mother' India with immortal glory." 105 Again, here we can read "purify", a term of great significance to Hindu religiosity, as synonymous with 'liberate'. It is thus clear that Ganapati perceived Ramana as a

\footnotetext{
${ }^{100}$ Vasishtha Ganapati Muni, Śrī Ramaṇa Gītā, trans. by K. Swaminathan (Tiruvannamalai: Sri Ramanasramam, 2004), 91.

${ }^{101}$ See Alaister McGlashan, The History of the Holy Servants of Lord Siva: a translation of the Periya Puranam of Cekkilar (Victoria, BC: Trafford Publishing, 2006), 171-265.

102 Arunachala's Ramana, vol. I, 12.

${ }^{103}$ Ibid. Rama, of course, did indeed carry and use a bow.

${ }^{104}$ Ibid., 13.

105 Ibid.
} 
divine answer to British oppression and India's struggle for political liberation. To Ganapati, Ramana is more than a guru or a sage; he is the symbolic figure upon whom he can base his political ambitions.

Ramana's abode, Arunachala, also had an important role to play in Ganapati's political vision. Ganapati believed that an empire would arise around a founding city shaped like the Śrī Cakra yantra (a sacred diagram of nine intersecting triangles used in Śrī Vidyā worship of the Goddess), ${ }^{106}$ and held that Arunachala geometrically matched this yantra. This point features in Uma Sahasram, in which Ganapati equated Arunachala to "the Śrī Cakra with nine entrances." ${ }^{107}$ In the context of speaking about Hampi as a capital of a great empire built on the Śrī Cakra model, Ramana referred to Ganapati's ambitions for Arunachala as follows:

Our Nayana (Ramana's name for Ganapati, meaning 'father' in Telugu) used to feel that as this town is by nature itself built on the Śrī Cakra model by the gods themselves, if only we could build houses all around the hill and make a city of it, this will become the capital of a big empire. He used to be always thinking and speaking of swaraj, dreaming and planning for it and saying what he would do when swaraj is attained. ${ }^{108}$

Ramana's statement confirms Ganapati's vision for Arunachala as the capital of a future empire, and importantly, demonstrates Ramana's awareness of Ganapati's preoccupation with India's political liberation.

Ramana was of course included in this vision, in which he would play the role of rishi or Vedic "emperor." ${ }^{109}$ Ganapati went as far as to draw up a plan for the city's construction - replete with a special place for "emperor" Ramana as well as plans suitable for the administration of the "empire." ${ }^{110} \mathrm{~A}$. V. Ramana

\footnotetext{
${ }^{106}$ Ganapati's disciple, K. Natesan, affirms that Ganapati’s family were Śr̄̄ Vidyā initiates. Śr̄̄ Vidyā corresponds to the cult of Lalita Tripurasundarī (Beautiful Goddess of the Three Cities) and constitutes a tantric form of worship of the Goddess, particularly in form of a yantra (sacred diagram), known as Śrī Chakra. The cult was adopted by the southern Daśanāmi monastic order based in Sringeri and Kanchipuram, a Vedāntic institution founded by Śankara. The cult also found a popular footing in the Śaiva Smārta community, as well as being adopted by the orthodox monastic institutions of the Śankkarācāryas. See Gavin Flood, An Introduction to Hinduism (Cambridge: Cambridge University Press, 1996), 187-88. A Śrī Cakra was consecrated in the Mother's temple at Sri Ramanasramam, and Śrī Cakra pūjā is performed every Friday in the temple.

${ }^{107}$ Ramana, Maha Tapasvi, 101.

108 Arunachala's Ramana, vol. 1, 297.

${ }^{109}$ Ibid., 256.

110 Arunachala's Ramana, vol. I, 227.
} 
asserted that Ganapati wanted a Vedic university to be established at the spot where Sri Ramanasramam now stands. ${ }^{111}$ Ganapati's vision of Ramana as Vedic rishi "emperor" completes his varying, and highly political conceptions of Ramana.

In sum, this section has stressed that Ganapati Muni held the conviction that he was born on earth to fulfil a political mission, and further, that both the mission and himself were divine in nature. More importantly, I have demonstrated that Ganapati perceived Ramana as intimately connected to this political mission. This point has been supported by Ganapati's alternative conceptions of Ramana, i.e. as Skanda, the god of war, as Campantar, the Tamil saint who restored dharma to society, and as the Vedic rishi "emperor", along with his vision that Arunachala would become the capital of a future empire.

\subsection{Ramana's "great love” for Ganapati and support for nationalism}

This section presents Ramana's highly positive attitude towards Ganapati Muni. I claim that Ramana's explicit awareness of Ganapati's political agenda, as seen above, plus the longevity and closeness of their relationship, and the high esteem with which Ramana regarded Ganapati, suggests that he was at least sympathetic, if not supportive, of Ganapati's political activities. I further argue that these points demonstrate a willingness to participate in Ganapati's political agenda. To supplement and support these points I reveal evidence of Ramana endorsing Indian nationalism in two ways: (1) symbolically, as in the case of raising the Indian flag on Independence Day, and as seen in his reverence towards Gandhi, who, according to Ramana, had the divine duty to achieve swaraj (home-rule); and (2) verbally, through his positive comments about Gandhi and swaraj. This section therefore directly challenges Arvind Sharma's claim that Ramana represents "the one figure of neo-Hinduism from whom nothing in support of even Indian nationalism could be extracted even at the height of the independence struggle," 112 and thus presents Ramana to be more politically inclined, or interested, than previously assumed.

\footnotetext{
111 Ramana, Maha Tapasvi, 232.

${ }^{112}$ Sharma, "Jivanmukti in Neo-Hinduism: the Case of Ramana Maharshi", 218.
} 


\subsubsection{Ramana on Ganapati}

Bhikshu's Telugu biography of Ramana perhaps best demonstrates Ramana's positive view of Ganapati. Bhikshu asserted that Ramana "had a great love for Ganapati," including his "exalted ideals." ${ }^{113}$ As Bhikshu's biography had been published by Sri Ramanasramam, and moreover, as there is evidence that Ramana had himself checked this version before its publication, ${ }^{114}$ Bhikshu's latter comment in particular is highly provocative. As seen above, we know that Ganapati's ideals were highly political, and as such, for Ramana to 'love his exalted ideals' suggests that he not only greatly admired Ganapati, but indeed supported his political ambitions.

Ramana's response to Ganapati's passing in 1936 supports Bhikshu's previous statement. Balarama Reddy reported that Ramana's reaction to the news, which he personally witnessed, had been unusually emotional, and that Ramana said affectionately: "Where will we find another like him?"115 Ramana's reaction may at first seem natural or even insignificant, but a comparison to the detached and unemotional response seen at the time of his own mother's death (who died in his arms in 1922) reveals the extent of the poignancy. ${ }^{116}$ Ramana's response, taken literally, indicates that he held Ganapati in the highest regard.

Ramana's relationship with Ganapati spanned three decades, during which time Ganapati always held a privileged and influential position. Ramana always referred to Ganapati as 'Nayana' (Telugu for father), a point which further underlines the deep respect that he reserved for Ganapati. As mentioned above, the number of Ramana's followers dramatically increased with the arrival of Ganapati and his own followers in 1907, suggesting that until at least the late 1920s, Ramana's following was one he largely shared with Ganapati. Bhikshu explained: “Ganapati's disciples were all Bhagavan's disciples too. They were spread all over the country and they carried forward Bhagavan's message." 117 Given the political agenda of Ganapati's own travels throughout India, we can infer here that their shared following strongly connected Ramana's 'message' and example with Ganapati's objectives. The longevity of their relationship, coupled

\footnotetext{
113 Bhikshu, Sri Ramana Leela, 102.

${ }^{114}$ A. Devajara Mudaliar, Day by Day with Bhagavan (Tiruvannamalai: Sri Ramanasramam, 2002), 129.

${ }_{115}$ Reddy, My Reminiscences, 55.

${ }^{116}$ See Osborne, Ramana Maharshi and the Path of Self-Knowledge, 83.

${ }^{117}$ Bhikshu, Sri Ramana Leela, 103.
} 
with no available evidence that Ramana attempted to distance himself from Ganapati or his political followers, demonstrates that Ramana was at least sympathetic to, if not supportive of, Ganapati's political agenda.

If, then, we consider (1) that there is evidence that Ramana greatly admired Ganapati and his "exalted ideals"; (2) the duration and intimacy of Ramana's relationship with Ganapati, along with their shared following; and (3) that Ramana appears to have made no attempt to disassociate or distance himself from Ganapati and his followers, there is enough evidence that Ramana did indeed support Ganapati's political agenda, and further, that he was prepared to play the strategic, symbolic role he had been assigned. Ramana was certainly not as politically proactive, aggressive or radical as Ganapati, but these points depict a willingness to participate in Ganapati's mission.

\subsubsection{Ramana symbolically endorsing nationalism}

Ramana's positive attitude towards and relationship with Ganapati suggests that Ramana was more politically aware and inclined than previously assumed. The remainder of this section provides additional evidence of Ramana illustrating both concern and support for India's independence. Note that the evidence I provide here is not exhaustive. I have opted to only provide the most striking examples, which I consider to be sufficient to support my claim.

The most provocative act, which vividly demonstrates Ramana's support for India's liberation, occurred on 15 August 1947, the day of India's Independence. K. Chandrasekharan reported that Ramana "hoisted the flag on that day atop the dining hall and there were tears in his eyes when he hoisted the tricolour flag." 118 The imagery evoked here not only indicates support for Indian nationalism, but suggests that India's attainment of independence had been a deeply poignant moment for Ramana. This was not the only occasion Ramana was seen with the Indian flag. During the Golden Jubilee celebrations in 1946, Ramana spent the majority of the day giving darśan on a sofa covered with the Indian flag. The sofa had also been decorated with khaddar clothes as well as cloth bearing the picture of the spinning wheel - two highly Gandhian and

\footnotetext{
118 Arunachala's Ramana, vol. III, 763. Omandur Ramaswamy Reddiar, Chief Minister of Madras Presidency, was present at Sri Ramanasramam on Independence Day, further politicising Ramana and his ashram. On a recent visit to Sri Ramanasramam as part of my research for this thesis, I personally witnessed the ashram's tradition of hoisting the national flag on Independence Day.
} 
nationalistic symbols. ${ }^{119}$ These provocative symbolic moments alone prove Sharma's statement to be misleading.

Ramana's reverential attitude towards Gandhi, the iconic symbol of India's liberation, further highlights Ramana's support for Indian nationalism. K. Swaminathan, editor of Gandhi's Collected Works, stated that Ramana often equated Gandhi with Hanuman, "the humble and heroic servant of Rāma." 120 Ramana even described Gandhi as "enlightened." ${ }^{121}$ In addition, there is evidence that several images of Gandhi were displayed in the ashram during the 1930s and 40s. ${ }^{122}$ In the early 1930 s, M. S. Kamath stated that "the only permanent fixture in the hall is a bust of Mahatma Gandhi with a yarn garland." 123

Ramana's emotional response to Gandhi's death again illustrated his reverence for Gandhi, including his view of Gandhi as the symbol of swaraj. On the morning after Gandhi's assassination, Ramana said, in a "voice choked with emotion", that his "heart", like everyone else's, was "mourning." ${ }^{124}$ Suri Nagamma observed that Ramana could be seen with tears in his eyes on two other occasions that day while listening to musical tributes to Gandhi. ${ }^{125}$

Ramana's tribute to Gandhi later that afternoon signified that he conflated Gandhi with swaraj. According to Suri Nagamma, Ramana related a story from the Uttara Rāmāyaṇa, which concludes with Yama telling Rāma that the work for which he had come had been completed, and that it was time for him to return to heaven. Ramana stated: "This is similar, swaraj has been obtained; your work is over; why are you still here? Shouldn't you go back?" ${ }^{126}$ Again, Ramana conceived of Gandhi as a godly figure, and on this occasion, clearly as someone sent for the divine mission of attaining swaraj for India.

\footnotetext{
${ }^{119}$ Ibid., vol. VI, 63-64.

${ }^{120}$ Arunachala's Ramana, vol. IV, 17.

121 Suri Nagamma, Letters from Sri Ramanasramam, vol. I \& II, Trans. D. S. Sastri (Tiruvannamalai: Sri Ramanasramam, 2006), 372.

${ }^{122}$ There are photographs of Ramana taken in the mid to late 1940s in which Gandhi's image is also included. Gandhi's face above the Indian flag can be seen in one example (see Arunachala's Ramana, vol. VIII, opposite 29), along with several other examples in which a cushion with Gandhi's image is positioned next to Ramana when seated on his sofa (see Arunachala's Ramana, vol. VIII, opposite 41, 140, 172.).

${ }^{123}$ Kamath, My Motherland, 15. K. Arunachalam supports Kamath's statement. He visited Sri Ramanasramam in 1932 and noted an 18 inch statue of Gandhi in the hall. See Arunachala's Ramana, vol. III, 31.

${ }^{124}$ Ibid., 370.

125 Ibid.

${ }^{126}$ Ibid., 370-71.
} 
These points clearly show that Ramana revered Gandhi and supported swaraj. This claim was supported by the powerful symbolism of Ramana emotionally raising the Indian flag on Independence Day, and the various images of Gandhi in Ramana's ashram. Further support may be seen in Ramana's positive comments on Gandhi and swaraj, which immediately follow.

\subsubsection{Ramana verbally endorsing nationalism}

We have seen that Ramana revered Gandhi and conflated him with swaraj. In addition to demonstrating concern and support for Indian nationalism in various symbolic ways, there are several examples of Ramana verbally endorsing swaraj and urging for Gandhi's example to be followed. At stake here is a willingness to engage in political discussion, which shows that Ramana was not solely concerned with the spiritual sphere.

M. S. Venkataramiah's following account exemplifies Ramana's stance on Gandhi's example. ${ }^{127}$ On 28 September 1938, a group of unnamed Congressmen posed three questions to Ramana concerning India's chances of independence. Venkataramiah stated that Ramana did not "categorically" answer these questions, but instead replied: "Gandhiji has surrendered himself to the Divine and works accordingly with no self-interest. He does not concern himself with the results but accepts them as they turn up. That must be the attitude of national workers." 128 According to Venkataramiah, Ramana concluded: "Follow the example of Gandhiji in the work for the national cause. 'Surrender' is the word." $" 129$ Venkataramiah then described a similar instance that occurred on the same day, in which four representatives from the Coorg Congress Committee requested a message from Ramana, to which he repeated his earlier message. ${ }^{130}$ Here, Ramana clearly showed approval and support for Gandhi and swaraj.

Two further examples follow the sentiment of the previous case. First, K. Arunachalam admitted that Ramana encouraged him to continue his work "with great devotion and detachment," just as Gandhi prescribed. ${ }^{131}$ Second,

\footnotetext{
${ }^{127}$ Mungala S. Venkataramiah was compiler of Talks with Sri Ramana Maharshi and Ramana's English translator during the 1930s.

${ }_{128}$ Mungala S. Venkataramiah, Talks with Sri Ramana Maharshi (Tiruvannamalai: Sri Ramanasramam, 2006), 521.

129 Ibid.

${ }^{130}$ Ibid.

${ }^{131}$ Arunachala's Ramana, vol. III, 31-33.
} 
Venkataramiah observed that Ramana counselled two young men, who came to him seeking a blessing to travel to Yeravada to fast with Gandhi, as follows: "It is a good sign that you have such feelings. But what can you do now? Get the strength which Gandhiji has already got by his tapasya. You will afterwards succeed." 132 Both these examples show Ramana responding positively to their willingness to support the nationalist cause, and again urging that Gandhi's example be followed.

On 14 August 1938, two of Gandhi's close associates, Rajendra Prasad and Jamnalal Bajaj, visited Sri Ramanasramam. Before leaving, Rajendra Prasad informed Ramana that Gandhi had sent him and requested a message to take him. Ramana responded as follows: "What message is needed when heart speaks to heart? The same śakti (power) which is working here is also working there!" 133 Ramana's reply was certainly ambiguous, if not cryptic, yet also highly positive. Ramana certainly made no attempt to distance himself from Gandhi, but rather suggested a commonality between them, and perhaps a shared understanding and inspiration.

During the same visit, Jamnalal Bajaj asked Ramana if "the desire for swaraj" was right. Ramana replied: "Such desire no doubt begins with selfinterest. Yet practical work for the goal gradually widens the outlook so that the individual becomes merged in the country. Such merging of the individuality is desirable and the related karma is nishkama (unselfish)."134 Although Ramana did not explicitly respond in favour of swaraj, he did not avoid the question, nor reject the desire for swaraj. Due to his conflating the desire for swaraj with unselfish karma, I suggest that Ramana responded in a way which encouraged working for swaraj in a Gandhian way, i.e. as a spiritual act. I further suggest that Ramana attempted to offer an answer which conformed to the principles of karma yoga propounded in the Bhagavad Gitāa, in which one should be detached from the sense that the individual performs actions, or from concern for their results. ${ }^{135}$ Gandhi's regard for the Bhagavad Gittā is well known, and it is therefore likely that Ramana tailored his response to advocate Gandhi's method for the benefit of Gandhi's colleague.

\footnotetext{
132 Ibid., 530.

${ }^{133}$ Golden Jubilee Souvenir (Tiruvannamalai: Sri Ramanasramam, 1946), 247.

${ }^{134}$ Ibid., 501.

${ }^{135}$ Bhagavad Gìtā (3.3-35), trans. by Juan Mascaro (New Delhi: Penguin Classics, 1962), 56-59.
} 
In sum, this section has demonstrated that Ramana was at least sympathetic, if not supportive of Ganapati's political activities, and importantly, that he was willing to participate in Ganapati's political agenda by playing the strategic role he had been assigned. To supplement these points, we have seen evidence that Ramana both symbolically and verbally endorsed Indian nationalism. Ramana therefore appears more politically inclined, or interested, than scholarship on Ramana assumes or allows.

\subsection{Conclusion}

We have seen that Ganapati Muni was primarily concerned with liberating India and establishing a reformed society based on Vedic principles, and that this concern spanned the period from 1904 until his Congress membership in the 1920s. Further, he believed that spiritual powers acquired through austerities would fulfil these political objectives, and as such, his preoccupation with tapas was explicitly driven by political motives. Ganapati's extensive political activities therefore demonstrate that his construction of Brahmana Swami as 'Bhagavan Sri Ramana Maharshi' was politically determined, and not solely dependent on his recognition of Ramana's supposed spiritual greatness. This claim has been supported by Ganapati's additional conceptions of Ramana, as incarnations of Skanda or Campantar, or as the Vedic rishi emperor of a future empire based at Arunachala. These points dramatically contrast Ganapati's portrayal in hagiographical literature on Ramana, which as I have argued, made a calculated effort to deny the political sphere in order to preserve a purely spiritual representation of Ramana.

In addition to the political orientation that Ganapati brought to Ramana's life, we have seen that Ramana was politically inclined. This point sharply contrasts his representation as purely spiritual in major hagiographical sources (such as Osborne and Narasimha Swami) and scholarship alike. Thus, Ramana - as the Great Vedic Rishi - ought not be completely separated from the political sphere. Why, then, has there been such a dedicated effort to deny the political sphere in the Ramana narrative, when traditionally, the rishis were active 
in important social, political and worldly ways, and not seen as playing a purely spiritual role? ${ }^{136}$

I contend that the Orientalist dichotomy of 'the East'/spiritual/rishi on the one hand, and 'the West/material/political ruler on the other hand, significantly influenced constructions of Ramana. In other words, early hagiographers considered that a 'purely spiritual' representation was required to legitimise Ramana's claim to rishi status. Ramana therefore represents a shift in the ways in which the rishis were interpreted in the Hindu religious tradition, a point that again firmly connects Ramana to the colonial encounter.

It is evident that Vedic Aryanism and the rishi ideal deeply influenced Ganapati's own thinking and ambitions. In 1907, Ganapati projected these colonially-shaped ideals onto an ascetic Tamil Śaiva and transformed him into a pan-Indian symbol, a Maharshi. Not only is there a vast semantic gulf between 'Brahmana Swami' and 'Bhagavan Sri Ramana Maharshi', but Maharshi itself represents a religious symbol capable of evoking a powerful response (see Chapter Two). Ramana's status as a Maharshi would affect the ways that he was perceived from 1907 onwards, as well as further depicted and constructed. As I demonstrate in Chapter Two, the Maharshi construct played an enormous role in winning pan-Indian and international popularity for Ramana, but it also allowed Ramana's example to be promoted in ways that aimed at generating national pride and vindicating Hinduism. Further, Ganapati's construction of the Maharshi symbol facilitated Ramana's eventual transition from a Tamil Śaiva bhakta to his casting as an Advaitin.

${ }^{136}$ Mitchiner, Traditions of the Seven Rishis, 218-225. 


\section{Chapter Two}

\section{The Vedic Rishi as 'national hero'}

\section{Introduction}

We have seen in Chapter One that Ganapati Muni's political ambitions played a decisive role in determining Ramana's status as a 'Maharshi'. Succinctly put, Ramana's standing as a 'Great Vedic Rishi' therefore demonstrates that he was significantly shaped by nationalism, and further, that he played a passive, symbolic role in the liberation movement.

This chapter expands on these points, looking at the process by which Ramana's reputation as a 'Maharshi' allowed him to acquire status as both 'national hero' and Advaitin. This process was largely dependent upon various Hindu intellectuals and political leaders who either celebrated Ramana's contribution to India during this transformative period, as in the case of Aurobindo, who deemed Ramana a "Hercules among yogis...who had won glory for India," ${ }^{1}$ or who promoted him as the living embodiment of Hindu truth. I argue that in the latter case especially, the motives to promote Ramana lay in the desire to vindicate Hinduism and generate national pride. $^{2}$

This chapter further argues that Ramana's construction as an Advaitin was contingent upon these currents and the Vedanticisation of Hinduism. The latter process entailed reformers such as Vivekananda and Radhakrishnan presenting the worldview of Hinduism as Advaita Vedānta. The origin of this process, however, lay in the efforts of early Orientalists who identified Vedānta as the principal doctrine of Hinduism. ${ }^{3}$ Ramana's status as 'the living embodiment of Hindu truth' meant that he also represented living proof of the Advaitin worldview. Again, the vindication of Hinduism is at stake.

I structure the chapter as follows: (1) I examine rhetorical frameworks in early literature on Ramana, focusing on Paul Brunton's A Search in Secret India (for reasons given below). This analysis demonstrates that the pan-Indian and international acclaim that Ramana received in the mid-1930s greatly

\footnotetext{
${ }^{1}$ Narain, ed., Face to Face with Sri Ramana Maharshi, 31.

${ }^{2}$ Halbfass has stated that both Ramana and Ramakrishna "were claimed and stylised by their followers as sources of authentication and validation of Hinduism in the modern world." See Halbfass, India and Europe, 384.

${ }^{3}$ King, Orientalism and Religion, 135.
} 
depended on the appeal of the mythic Maharshi symbol. I also elaborate on the traditional status of the rishis in Hindu religiosity to account for the strength of its appeal. (2) I present evidence that Hindu intellectuals and political leaders celebrated Ramana's importance to India and promoted him as the living embodiment of Hindu truth. This process constructed Ramana as the embodiment of a pan-Indian and orthodox Hinduism and influenced his categorisation as an Advaitin. This image signifies a dramatic shift from his pre-Maharshi status as an unorthodox, localised Tamil Śaiva ascetic and devotee of Arunachala. Without the external forces of the colonial encounter and Indian nationalism, such a dramatic shift is unlikely to have eventuated.

Additionally, this chapter shows Orientalist discourse to feature in the historical processes that shaped Ramana in several ways: First, we will see that Paul Brunton portrayed Ramana in way that echoed romantic Orientalist stereotypes about Indian spirituality, i.e. as mystical, timeless and otherworldly. Second, we will see the role of Orientalists in inaugurating the Vedanticisation of Hinduism, a process that fed into Ramana's categorisation as an Advaitin. In a broader sense, this chapter demonstrates an interesting case in which both Westerners and Indians have collaborated in creating Ramana's image through Orientalist assumptions, and importantly, an image that Indian nationalists utilised in an anti-British/imperial way. Therefore we see Orientalism functioning in a way that contrasts Said's thesis, which argued that European imperialism perpetuated Orientalism to dominate Asia. ${ }^{4}$

\subsection{The appeal of the mythic Maharshi symbol}

Ramana appears to have done very little - if anything at all - that would count as active self-promotion. ${ }^{5}$ If this is the case, how, then, did he receive pan-Indian and international acclaim during his lifetime? The initial attention that Ramana attracted relied in part on the publicising efforts of M. S. Kamath and B. V. Narasimha Swami during the early 1930s. The pan-Indian and international attention Ramana attracted from the mid-1930s onwards, however, relied heavily on the success of Paul Brunton's book, A Search in Secret India. Brunton's direct

\footnotetext{
${ }^{4}$ Said, Orientalism, 3.

${ }^{5}$ Halbfass also makes the point that Ramana never made an effort to spread his message. See Halbfass, India and Europe, 384.
} 
influence may be seen in Major Chadwick, the first Westerner to permanently reside at the ashram, ${ }^{6}$ Mercedes de Acosta, ${ }^{7}$ Professor Banning Richardson, ${ }^{8}$ Syed Hafiz, Professor of Philosophy at Allahabad University, ${ }^{9}$ Rudra Raj Pande, from Nepal, ${ }^{10}$ and Prof. Pryn Hopkins, an American social psychologist. ${ }^{11}$ Brunton therefore played a decisive role in Ramana's transition from a localised Śaiva ascetic to a pan-Indian rishi and world teacher to elites and intellectuals.

Given the importance of Brunton's influence, I present an analysis of $A$ Search in Secret India, focusing on the ways that he presented Ramana. I will show that Brunton employed a highly romanticised rhetoric that portrayed Ramana in a way that strongly conformed to Orientalist stereotypes about a 'mystical East', i.e. as ancient, timeless, otherworldly and purely spiritual. Importantly, Brunton drew heavily on the appeal of the mythic Maharshi symbol, which indicates that the mythic aura surrounding the Maharshi symbol played an immense role in establishing Ramana's wide-spread fame. To underline the appeal of the Maharshi symbol, I contextualise the rishis in Hindu religiosity, emphasising their exalted status and comparing it to Ramana's religious status prior to his construction as a Maharshi in 1907. I will also pay attention to Kamath and Narasimha, who were both participants in the nationalist movement (see section 2.2.1.).

\subsubsection{The mythic rishis}

The exalted status of the rishis (ṛsi) stems from their roles as progenitors, seers, composers of sacred hymns and mantras, and teachers to humankind. Maharshi (Mahā - Great, and ṛ̣i - seer) is one of several traditional labels applied to 'the Seven Rishis', who form the most important group of rishis in Hindu religiosity. ${ }^{12}$ Their eminence pervades the breadth of sacred Hindu literature, from the $R g$ Veda to the Rāmāyana.

\footnotetext{
${ }^{6}$ Major A. W. Chadwick, A Sadhu's Reminiscences (Tiruvannamalai: Sri Ramanasramam, 2005), 7.

${ }^{7}$ Narain, ed., Face to Face with Sri Ramana Maharshi, 282.

${ }^{8}$ Ibid., 27.

${ }^{9}$ Arunachala's Ramana, vol. III, 97.

${ }^{10}$ Narain, ed., Face to Face with Sri Ramana Maharshi, 59.

11 Arunachala's Ramana, vol. IV, 267.

${ }^{12}$ Mitchiner, Traditions of the Seven Rishis, xvi. The other terms applied to the Seven Rishis are; brahmarși, devarși, viprarși, and paramarși.
} 
The rishis are portrayed in the Mahäbhärata, the Rāmāyaña and Purānas as the progenitors of all orders of creation, including gods and men. John Mitchiner points out that the rishis receive more attention than gods in the Sanskrit epics, indicating that the rishis assume a highly esteemed status indeed in popular Hinduism. ${ }^{13}$ In Vedic literature, and especially the $R g$ Veda, the rishis are assigned the role of seers and composers of hymns. In fact, all hymns which comprise the $R g$ Veda are traditionally ascribed to one of the rishis. ${ }^{14}$ A role of such importance in Hinduism's earliest and foundational sacred texts, affirms the exalted status of the rishis. Puranic literature, on the other hand, emphasises the rishis in the role of teacher, and more precisely, the role of teaching the Vedas and dharma to humankind. ${ }^{15}$ Due to these roles and their pervasive place in sacred Hindu texts, we can conclude that the rishis are revered by Hindus on a panIndian level as orthodox and supreme religious authorities. As seen above, Vivekananda conceived of the rishis in this manner, and greatly emphasised their status as "perfect beings" and the "ideal" of Hinduism. ${ }^{16}$

Prior to Ganapati Muni's construction of Ramana as a Maharshi, Ramana was known in the Arunachala area as Brahmana Swami. During this period, both ascetics and householders would have perceived Ramana along similar lines to the numerous other ascetics in the area - as a Tamil Śaiva and devotee of Arunachala. However, Ramana was distinguished from other ascetics in that he was never formally initiated into an orthodox renunciate tradition or lineage. Ramana's ascetic status between 1896 and 1907 may be characterised as unorthodox, localised and ethnic-sectarian, an image which differs dramatically to the pan-Indian, orthodox and mythic status of the 'Great Vedic Seer' he embodied after 1907. The Maharshi construct thus represents a dramatic shift in Ramana's religious status.

Further, the Maharshi construct also carried tremendous symbolic appeal. This appeal carried even more weight during the colonial period, and in relation to nationalism in particular, due to the prominent role religious symbols

\footnotetext{
13 Ibid., Xv.

14 Ibid., 171-72.

15 Ibid., 182.

${ }^{16}$ Vivekananda, Selections from Swami Vivekananda, 5, 298-99.
} 
played in the agendas of Bankim Chandra Chatterjee, ${ }^{17}$ Abindranath Tagore, ${ }^{18}$ the Arya Samaj, ${ }^{19}$ Tilak, ${ }^{20}$ Aurobindo, ${ }^{21}$ and Gandhi, ${ }^{22}$ to name a few. The success Gandhi won with this strategy indicates a climate of receptivity to religious symbols during the very time that Ramana acquired his pan-Indian and international fame. Swami Chinmayananda, disciple of Swami Sivananda and founder of the Chinmaya Mission, described the appeal of the Maharshi symbol: "The word Maharshi conjured up in my mind ancient forest retreats and superhuman beings of divine glow." ${ }^{23}$ Thus, the Maharshi symbol was particularly powerful to certain Hindus during the nationalist period. This symbol was exploited with great success by Paul Brunton.

\subsubsection{Paul Brunton and "the Maharishee"}

On his first visit to Sri Ramanasramam (Ramana's ashram) in 1931, Paul Brunton noted that there were only a handful of resident disciples. ${ }^{24}$ After the publication of Brunton's A Search in Secret India in 1934, the number of visitors to the ashram exploded. S. S. Cohen, an Iraqi devotee who arrived in 1936, wrote of "a constant influx of visitors," which perpetually increased until it "realised its zenith in 1950." ${ }^{25}$ We get a sense of Ramana's popularity towards the end of his life from the fact that a crowd of 15,000 people attended the consecration ceremony of the Mathrubhuteswara temple in $1949,{ }^{26}$ and 40,000 came to the ashram following Ramana's passing. ${ }^{27}$ Visitors came from all over India and the world,

\footnotetext{
${ }^{17}$ Bankim Chandra Chatterji, "Bande Mataram," in Sources of Indian Tradition, vol. II, ed. and revised by Stephen N. Hay (New York: Columbia University Press, 1988), 159-60.

${ }^{18}$ Sekhar Bandyopadhyay, "Introduction," in Nationalist Movement in India: a Reader, ed. Sekhar Bandyopadhyay (Oxford: Oxford University Press, 2009), xx.

${ }^{19}$ Bandyopadhyay, From Plassey to Partition, 240-41.

${ }^{20}$ Ibid., 243-44.

${ }^{21}$ Ibid., 256-57.

${ }^{22}$ David Arnold, Gandhi: Profiles in Power (New York: Longman, 2001), 165; Margaret Chatterji, Gandhi's Religious Thought (Notre Dame: University of Notre Dame Press, 1983), 31; Bandyopadhyay, From Plassey to Partition, 292.

${ }^{23}$ Narain, ed., Face to Face with Sri Ramana Maharshi, 225.

${ }^{24}$ Brunton, A Search in Secret India, 102. Paul Brunton was an author and journalist, who was born Raphael Hurst in London, 27 November 1898. Before travelling to India in 1931, he was influenced by Spiritualism and Theosophy. His quest in India was to find a 'Master'. Brunton died in Switzerland in 1981. His other published works include The Secret Path (1935), A Search in Secret Egypt (1936) and A Message from Arunachala (1936).

${ }^{25}$ S. S, Cohen, Guru Ramana (Tiruvannamalai: Sri Ramanasramam, 2003), 12-17.

${ }^{26}$ Ibid., 115.

${ }^{27}$ Ibid., 158.
} 
and from as far away as New Zealand and Peru. ${ }^{28}$ As Arthur Osborne rightly observes, "none did more to spread knowledge" of Ramana "through the world than Paul Brunton with his book, A Search in Secret India.",29

Brunton's Orientalist portrayal was pivotal in Ramana's transition from a localised Śaiva ascetic to a pan-Indian rishi and world teacher to elites and intellectuals. In A Search in Secret India, Brunton referred to Ramana exclusively as "the Maharishee" (Maharshi). By contrast, devotees of Ramana, especially those who resided at the ashram, referred to him as 'Bhagavan' (Lord). This suggests that Brunton opted to call Ramana "the Maharishee" on account of the symbolic weight of the epithet. Brunton saw the rishi as the highest form of yogi (practitioner of yoga), one who "exert[s] their influence in a silent and unknown manner," and importantly, as belonging to a glorified past. ${ }^{30}$ Brunton's agenda was largely concerned with presenting Ramana as an enigmatic, otherworldly figure from a hidden ancient tradition that he himself had encountered. This point may be corroborated by his explanation for entitling the book A Search in Secret India. Brunton writes: "I have titled this book Secret India because it tells of an India which has been hidden from prying eyes for thousands of years." 31 These statements are indicative of the Orientalist assumptions that characterised Brunton's work.

The mythic Maharshi symbol dominated Brunton's romanticised portrayal of Ramana. Brunton's description of his journey to Ramana's ashram, which he labelled a "forest hermitage" at "the foot of a sacred Hill", along with his first encounter with "the Maharishee", aimed at generating an enigmatic and otherworldly atmosphere. ${ }^{32}$ Brunton wrote of a "loin cloth" clad "Maharishee", who sits in a "half-Buddha posture" on a raised divan from the several devotees who surround him, while "burning incense fills the air." 33 Brunton characterised Ramana as "the most mysterious personality" he has met, further claiming that he detected in Ramana "a mysterious property...which differentiates him from all

\footnotetext{
${ }^{28}$ Narain, ed., Face to Face with Sri Ramana Maharshi, 288; Arunachala's Ramana, vol. III, 529.

${ }^{29}$ Osborne, Ramana Maharshi and the Path of Self-Knowledge, 182.

${ }^{30}$ Brunton, A Search in Secret India, 19-21.

31 Ibid., 10.

32 Ibid., 99-101.

${ }^{33}$ Ibid., 118.
} 
others." 34 Brunton alleged to immediately discern that Ramana stood elevated above "common humanity," declaring him "a Maharishee worthy of the name.",35

That Brunton - a Westerner - presumed to have immediately discerned a special quality in Ramana that qualified his status as a Maharshi provided a striking endorsement to both Western and Indian readers. Moreover, since Brunton's descriptions strongly echoed Orientalist stereotypes about Hindu spirituality, his success indicates how powerfully the Orientalist dichotomy of East and West captured the socio-political landscape during nationalism.

Brunton fortified the Orientalist character of his portrayal by projecting ancient and timeless qualities onto Ramana. Brunton described Ramana as "a child of a remote past,"36 a sage in a line of "ancient prophets," 37 and as "one of the last of India's spiritual supermen." 38 He further stated that "the serene figure of this ancient sage brings the legendary figures of his country's ancient Rishees nearer to me." 39 Brunton clearly wished to present Ramana in the most romanticised fashion possible to exploit Western imaginations fascinated with the supposed mystical, timeless Orient, a strategy that worked to great effect. Further, Brunton's treatment of Ramana as a timeless, ancient figure has forged a lasting legacy, which as we have seen, has even been surprisingly assumed in scholarship on Ramana.

Brunton's success was likely to have been driven by the political landscape of the 1930s, and in particular, Gandhi's image, which was associated with asceticism and ashrams. I suggest that Gandhi's importance here is twofold. First, Hindu religious symbols featured significantly in Gandhi's political campaign, and thus his success in rallying and unifying the masses of India indicates a climate of receptivity to religious symbols. Second, like key Hindu leaders such as Roy, Saraswati and Vivekananda, Gandhi took the pejorative stereotypes and assumptions of Orientalists, such as effeminacy, spirituality, otherworldliness, antiquity and tradition (as opposed to modernity), and used them

\footnotetext{
${ }^{34}$ Ibid., 110-11.

35 Ibid., 111.

${ }^{36}$ Ibid.

${ }^{37}$ Ibid., 119.

${ }^{38}$ Ibid., 217.

${ }^{39}$ Ibid.
} 
as weapons to expel the British. ${ }^{40}$ Ronald Inden stresses the role of Orientalism in this political strategy:

In many respects the intellectual activities of the Orientalist have even produced in India the very Orient which it constructed in its discourse. I doubt very much, for example, if Gandhi's concept of non-violence would have played the central part it did in Indian nationalism had it not been singled out long ago as a defining trait of the Hindu character. ${ }^{41}$

Just as Orientalist assumptions about India contributed to Gandhi's popularity and political strategies, these assumptions also influenced Brunton's romantic portrayal of Ramana, and likewise, his success in winning acclaim for "the Maharishee". In other words, the popularity that Gandhi and Ramana enjoyed owed much to public personas that were freighted with Orientalist qualities.

In sum, an analysis of A Search in Secret India has shown that Brunton portrayed Ramana as a purely spiritual and otherworldly figure, whose romanticised image brings the reader into contact with an imagined ancient and timeless religious tradition. This depiction conformed strongly to Orientalist stereotypes concerning Hindu spirituality, a factor which would have allowed this image to resonate in Western audiences, as well as in Indian intellectual circles. Moreover, Brunton successfully exploited the appeal of the mythic Maharshi symbol, which as we saw with Swami Chinmayananda, possesses the power to conjure up "ancient forest retreats and superhuman beings of divine glow," and in so doing, brought Ramana pan-Indian and international fame and "a constant influx of visitors." Importantly, this fame attracted both political leaders, such as Morarji Desai, C. Rajagopalachari and O. P. Ramaswamy Reddiar, who would celebrate Ramana's contribution to India, and Hindu intellectuals, such as S. Radhakrishnan, B. L. Atreya and T. M. P. Mahadevan, who promoted Ramana as a source of Hindu pride and as an Advaitin.

\subsection{The 'national hero': Ramana as the living embodiment of Hindu truth}

This section will complete my analysis of the process by which Ramana's reputation as a Maharshi led to his status as a 'national hero'. Various Hindu

${ }^{40}$ King, Orientalism and Religion, 134.

${ }^{41}$ Inden, Imagining India, 38. 
intellectuals and political leaders either celebrated Ramana's contribution to India or promoted him as the living embodiment of Hindu spiritual truth. I argue that the social and political agenda of Hindu elites who so acted, such as S. Radhakrishnan and T. M. P. Mahadevan, was to vindicate Hinduism and generate national pride. As exemplified by the cases of Radhakrishnan and Mahadevan, these currents gave rise to Ramana's categorisation as an Advaitin, a construction which continues the image-shaping process that began with Ganapati Muni's Maharshi construct. This further demonstrates that nationalism deeply shaped the ways that Ramana was represented. ${ }^{42}$

This section explicitly raises the interesting relationship between the spiritual and the political within the context of Indian nationalism. Peter van der Veer underlines the role of Hindu spirituality in "nationalist discourse", describing it as a "principal theme" throughout the nationalist era. ${ }^{43}$ Furthermore, Hindu leaders tended to emphasise religion as a defining feature of national identity. ${ }^{44}$ Gandhi exemplified the interconnectedness of the spiritual and nationalist politics, but his open and aggressive political ambition distinguished him from Ramana in obvious ways. ${ }^{45}$ Ramana's case in this context demonstrates the importance of the purely spiritual to Indian nationalism, and to the ways that many Hindus conceived of national identity during this period, on account of his construction as the embodiment of Hindu ideals. While Ramana's role may have been symbolic, he ought to be seen as an important figure in India's struggle for independence. Further, Ramana's wide-spread and enduring recognition largely derived from the unique socio-political landscape during the nationalist era. These points challenge an ahistorical analytical approach or representation.

To underline the link between Ramana's alleged lofty spiritual status and its value to Indian nationalism, I first draw attention to the political pursuits of authors publishing material on Ramana prior to Paul Brunton, such as M. S. Kamath, B. V. Narasimha Swami and Suddhananda Bharati. I then present high profile political leaders such as C. Rajagopalachari, O. P. Ramaswamy Reddiar and Morarji Desai, who celebrated Ramana's spiritual contribution to India,

\footnotetext{
${ }^{42}$ Note that I challenge Ramana's claim to Advaitin status below (see Chapter Three), which will provide further support to arguments presented in this chapter.

${ }^{43}$ van der Veer, Imperial Encounters, 46.

${ }^{44}$ Bandyopadhyay, From Plassey to Partition, 234; van der Veer, Religious Nationalism, 23.

${ }^{45}$ Bandyopadhyay, From Plassey to Partition, 286.
} 
followed by intellectuals such as S. Radhakrishnan, B. L. Atreya and T. M. P. Mahadevan, who further celebrated Ramana's spiritual contribution to India, but who also clearly promoted him as an Advaitin.

\subsubsection{The political pursuits of early biographers}

Prior to Paul Brunton's A Search in Secret India, B. V. Narasimha Swami, Suddhananda Bharati and M. S. Kamath produced the main sources of biographical information on Ramana. Like Ganapati Muni, who produced the first published account of Ramana's teachings (Śrī Ramaṇa Gìtā), these three were all involved in nationalist activities. The connection seen here indicates that Ramana - the purely spiritual Maharshi - represented a powerful pan-Hindu symbol that could serve the nationalist project.

B. V. Narasimha Swami authored the first major biographical work on Ramana, Self-Realization: the Life and Teachings of Sri Bhagavan Ramana Maharshi (1931). He also participated in the nationalist movement as a Congressman. ${ }^{46}$ The current president of Sri Ramanasramam, V. S. Ramanan, described Narasimha as "an ardent participant in the freedom struggle." ${ }^{47}$ Kamath stated that Narasimha was "well known throughout India as a fearless and assiduous politician. ${ }^{" 48}$ Narasimha thus represents a direct link between valuing the symbolism of Ramana's lofty spiritual status and concern for the nationalist cause. $^{49}$

Suddhananda Bharati authored the first Tamil biography, Ramana Vijayam (1931). Very little information is available on Bharati, though it is clear that he participated in nationalist politics during the 1920s and 30s, and that he

\footnotetext{
${ }^{46}$ Arunachala's Ramana, vol. II, 389. Narasimha Swami belonged to the Iyer caste, the same caste as Ramana.

${ }^{47}$ A. V. Ramanan, "Publisher's Note," in B. V. Narasimha Swami, Self Realization: the Life and Teachings of Bhagavan Sri Ramana Maharshi (Tiruvannamalai: Sri Ramanasramam, 2007), iii.

${ }^{48}$ M. S. Kamath, Sri Ramana Maharshi: a Biography with 111 Illustrations (Madras: The Sunday Times Bookshop, 1936), 33.

${ }^{49}$ Interestingly, it was Narasimha Swami who convinced Brunton to return to Ramana's ashram from Bombay instead of travelling home to London [see "Introduction" to Paul Brunton, The Maharshi and His Message (Tiruvannamalai: Sri Ramanasramam, 2000), vii-viii. Note that the author of the "Introduction" is not specified. This book contains the three chapters found in $A$ Search in Secret India that deal with Ramana]. This second visit would become the climax of $A$ Search in Secret India. Knowing that Brunton was a writer, Narasimha was seemingly highly motivated to spread knowledge of a living Maharshi by any available means. As seen above, Narasimha intervention here proved a major turning point in Ramana's life.
} 
was an associate of Ganapati Muni. ${ }^{50}$ Not only did Bharati promote the value of Ramana's spiritual status in writing, he also implicitly referred to Ramana during his last political speech, delivered in Tuticorin, Tamil Nadu. According to Bharati, "The spiritual India is already free. The material India shall be free through spiritual force...Purify and electrify your souls through yoga...The silent force of a silent sage is working behind the destiny of India." ${ }^{, 51}$ Bharati's statement appears in the context of a written piece in which he praises Ramana, thus we can conclude that the 'silent sage' he was referring to was indeed Ramana. According to Bharati, then, Ramana's alleged lofty spiritual state had the power to aid India's liberation effort, and was even precisely directed towards that objective. Thus, Bharati represents a further direct link between the value of Ramana's eminent spiritual status and nationalist concerns.

M. S. Kamath was the editor of The Sunday Times (Madras) during the 1930s, and the Tamil daily, Hindusthan, during at least the latter years of the 1930s. ${ }^{52}$ We see evidence of a nationalistic agenda in a series of pamphlets he published in the early 1930s under the title My Motherland. ${ }^{53}$ Overall, Gandhi dominates the subject matter of the sixteen pamphlets, in what was very much a work of nationalist propaganda, as the title suggests. Following the first pamphlet, "Mahatma Gandhi: The Superman of the Age", Ramana appeared second in the series under "Sri Ramanasramam: with a life sketch of the Maharshi". In addition to praising the quality of Ramana's ashram, Kamath emphasised Ramana's attitude of ahisma (non-violence), including his love and respect for animals. Kamath made an obvious attempt to draw parallels between the culture of Ramana's ashram and Gandhian values. In fact, Kamath linked Gandhi to the ashram by stating that "the only permanent fixture" in the main hall of the ashram "is a bust of Mahatma Gandhi with a yarn garland." 54

Further evidence to support the political nature of Kamath's activities may be seen in his accompanying close associates of Gandhi on their visits to

\footnotetext{
${ }^{50}$ Narain, ed., Face to Face with Sri Ramana Maharshi, 262-63.

${ }^{51}$ Ibid.

52 David Godman, Living by the Words of Bhagavan (Tiruvannamalai: Sri Annamalai Swami Ashram Trust, 1994), 50; Narain, ed., Face to Face with Sri Ramana Maharshi, 161.

${ }^{53}$ M. S. Kamath, My Motherland (Madras: The Sunday Times, Office). Note that this work was viewed at Sri Ramanasramam archives. Kamath followed up this work with a more extensive biographical work on Ramana in 1936, Sri Ramana Maharshi: a Biography with 111 Illustrations (Madras: The Sunday Times Bookshop, 1936).

54 Ibid., 15.
} 
Ramana's ashram. In 1935, Kamath accompanied Shankarlal Banker (who was sent by Gandhi), ${ }^{55}$ and in August 1938, he accompanied Congressmen Rajendra Prasad and Jamnalal Bajaj (who were also sent by Gandhi; see section 1.4.4), an event he then publicised on the front page of the Tamil daily, Hindustan. ${ }^{56}$ Kamath's promotion of Sri Ramanasramam can be seen to evaluate the symbolism of Ramana's prestigious spiritual reputation, along with his ashram culture, as not detached from the political realm and even beneficial to the nationalist cause.

The nationalist activities of Narasimha, Bharati and Kamath indicate that their motives in publicising and promoting Ramana's lofty spiritual status were certainly not confined to purely spiritual interests. Instead, their political involvement suggests that they considered Ramana's reputation as a Maharshi, including the symbolism it encompassed, of value to India's struggle for independence, whether in the more radical case of Bharati, or in the sense that Ramana personified the ideal of Hinduism. I suggest that early biographers of Ramana intended these very values to be celebrated and followed by the Hindu public in the same way that Gandhi was to be celebrated and followed. As we will now see, key political figures of the period also expressed similar sentiments.

\subsubsection{Political leaders celebrating Ramana}

Morarji Desai, O. P. Ramaswamy Reddiar and C. Rajagopalachari were among the nationalists to praise Ramana's contribution to India during the nationalist era. Given the high profile status of these political leaders, we again see the political value of a mythic religious symbol, one that represents a spiritual and apolitical authority in a pan-Hindu and orthodox way.

Morarji Desai, independence activist from the 1930s and Prime Minister of India (March 1977 to July 1979), visited Sri Ramanasramam in August 1935. Following his meeting with Ramana, Desai expressed the conviction that Ramana had attained the highest spiritual state according to Hinduism. ${ }^{57}$ During his tenure as Prime Minister, Desai celebrated Ramana as a national hero: "Many civilisations have flourished and then disappeared. But in

\footnotetext{
55 Arunachala's Ramana, vol. III, 46-47.

${ }^{56}$ Hindustan, 28 August 1938 edition. Viewed at Sri Ramanasramam archives.

57 "Cited in" Narain, ed., Face to Face with Sri Ramana Maharshi, 352. Desai wrote of this event in his autobiography, The Story of My Life.
} 
this country you find our old culture and the ancient religion still alive. And it is this that keeps the country alive. It is persons like the Maharshi who keep it alive." 58 Given that India's culture and religion had been attacked during the colonial encounter, Desai's celebration of Ramana as a contributor to India's survival during such a desperate period certainly promotes "the Maharshi" as a national hero.

A further example of Desai celebrating Ramana's value to India during the nationalist era may be seen in his article entitled "Maharshi and the Mahatma" ${ }^{59}$ Here Desai stressed the importance and status of Ramana by placing him alongside Gandhi. To make his point he concluded the article by quoting Sarojini Naidu (a poet and freedom fighter, also known as 'the Nightingale of India'):

We have two mahaans in India today. One is Ramana Maharshi who gives us peace. The other is Mahatma Gandhi, who will not let us rest one moment in peace. But each does what he is doing with the same end in view, namely, the spiritual regeneration of India.

In the context of the independence movement, there could have been no greater accolade than to consider someone in the same breath as Gandhi, arguably India's greatest hero of the modern era. As it would be misguided to view Gandhi's importance to India purely in terms of "spiritual regeneration", likewise it would be erroneous to confine Desai's celebration of Ramana's importance to the spiritual realm, particularly given the principal role Hindu spirituality played in nationalist discourse, as van der Veer pointed out.

A similarly politically charged depiction of Ramana may be seen in $\mathrm{O}$. P. Ramaswamy Reddiar. Reddiar was a noted freedom fighter, Congressman, and Chief Minister of Madras Presidency, 1947-49. He was present at Sri Ramanasramam on Independence Day in $1947,{ }^{60}$ the consecration ceremony for the 'Mother's Temple' in $1949,{ }^{61}$ and the day Ramana passed away. ${ }^{62}$ The Hindu

\footnotetext{
${ }^{58}$ Ibid., 353.

${ }^{59}$ Morarji Desai, "Maharshi and the Mahatma", the magazine section of The Sunday Standard, date unknown. This article was viewed at Sri Ramanasramam archives. Unfortunately I was unable to discern the date of the article.

${ }^{60}$ Arunachala's Ramana, vol. III, 763.

${ }^{61}$ Cohen, Guru Ramana, 113.

${ }^{62}$ Ibid., vol. VIII, 384.
} 
newspaper quoted Ramaswamy Reddiar commemorating Ramana after his passing as follows: "Mahatma Gandhi and Bhagwan Ramana Rishi were the symbols of karma yoga and jñāna yoga."63 Though this tribute is brief, there are two things to underline here: first, even though the context is predominately spiritual, by mentioning Ramana in the same breath as Gandhi, Reddiar ascribed to Ramana paramount value to India. Second, Reddiar's description of Ramana as the "symbol for jñāna yoga" means that Ramana represented or embodied the highest form of spiritual truth or knowledge according to Hinduism. The combination of Gandhi - with all the political associations that name carries - and Ramana as the embodiment of Hindu spiritual knowledge, clearly demonstrates that Reddiar endorsed Ramana's status of national hero.

C. Rajagopalachari, freedom fighter and the last Governor General of India, also depicted Ramana in a way that regarded him as a national hero. Rajagopalachari led a ceremony on June 23, 1948, which opened a newly constructed temple in the grounds of the Arunachaleswara temple complex. The occasion was to commemorate the Patala Lingam, an underground temple within which Ramana resided for several months when he first arrived in Tiruvannamalai. ${ }^{64}$ During the ceremony Rajagopalachari celebrated Ramana's contribution to India as follows:

The Maharshi has kept India's spiritual glory alive in our own generation. He has in his own way made the name of India respected by wise and enlightened men spread all over the world even as Sri Ramakrishna Paramahansa and other saints did in former times. ${ }^{65}$

The phrase "our own generation" is certainly understated, but significant when the generation in question waged a successful independence struggle and forged India as a nation. Rajagopalachari implied that by 'keeping India's spiritual glory alive', Ramana embodied and also testified to the correctness of Hindu spirituality, which as we have seen above, was a significant theme in nationalist discourse and central to the ways that many Hindus imagined an Indian national identity. Again,

${ }^{63}$ The Hindu, 15 April, 1950, 6.

${ }^{64}$ Cohen, Guru Ramana, 103-04.

65 "Cited in" The Hindu, Sunday 16 April, 1950. 
this point seen in light of modern India's most historically important period allows Ramana to assume the status of national hero.

On account of their praise for Ramana's contribution to India, Desai, Reddiar and Rajagopalachari participated in the trend of nationalists who promoted Hindu spirituality as a key aspect of national identity and pride. Thus, we have seen evidence that a mythic religious symbol, i.e. the Maharshi, represented political value during the nationalist era, which in turn, contributed to Ramana's status as a national hero. As we will now see, Hindu intellectuals of the period also promoted Ramana's spiritual and national value.

\subsubsection{Hindu intellectuals and the Advaita construct}

While the sentiment of Rajagopalachari's praise echoed Morarji Desai, Sarojini Naidu and Ramaswamy Reddiar in celebrating Ramana's value and contribution to India, it also reflected comments made by S. Radhakrishnan, B. L. Atreya and T. M. P. Mahadevan. The major point of difference between the two groups consisted of the latter constructing Ramana as an Advaitin.

Ramana's status as an Advaitin was significantly influenced by a process of Vedanticisation. Following Orientalist assumptions about 'true' Hinduism, Hindu leaders such as Vivekananda, Radhakrishnan and Gandhi contributed to the Vedanticisation of Hinduism. Advaita Vedānta therefore played an important role in the construction of a single, unified Hinduism, which in turn aided nationalism. Richard King states: "The representations of the Advaita Vedānta of Śankkarācārya as a powerful cultural symbolic provided the necessary material for the development of an inclusivistic and nationalist ideology for uniting Hindus." ${ }^{66}$ The key feature here is the relationship between Advaita, nationalism and the unification process. Ramana exemplified this relationship in significant ways, but most importantly, because Hindu intellectuals such as Radhakrishnan and Mahadevan constructed him as an Advaitin with nationalist concerns in mind, which included vindicating Hinduism. We therefore see the culmination of a process that began with Ganapati Muni, in which Ramana's religious status transformed from an unorthodox, localised Tamil Śaiva ascetic into an orthodox, pan-Hindu religious authority and proponent of Advaita

${ }^{66}$ King, Orientalism and Religion, 135. 
Vedānta. This section reveals another dimension to Ramana's symbolic role during nationalism, and to the ways in which he was significantly shaped by the colonial encounter.

Radhakrishnan's positive appraisal of Ramana displays motives beyond simply honouring his alleged spiritual attainments. Instead we see in Radhakrishnan evidence of his mission to promote Vedānta for nationalistic purposes. ${ }^{67}$ In his tribute to Ramana, Radhakrishnan ascribes an enormous societal duty to India's saints, describing them as "the sustainers of society." 68 Echoing Desai's sentiment concerning India's survival, Radhakrishnan elaborated that "the Indian tradition has been kept alive by seers who were born in every age and incarnated the great ideal." ${ }^{, 69}$ Radhakrishnan's agenda, which aims at vindicating Hinduism, is exposed by the following: "If religion is a living truth, if it has any vitality, it must be capable of producing men who from time to time bear witness to the truth and confirm and correct from their own experience the religious tradition. ${ }^{, 70}$ He then firmly invokes Ramana in this context, describing him as "a living embodiment of God-centred life, a perfect image of the life divine in the mirror of human existence," 71 and in so doing, attempts to demonstrate the superiority of Hinduism.

Importantly, Radhakrishnan categorises Ramana as an Advaitin, claiming that he "adopts the metaphysical position of Advaita Vedānta." 72 Radhakrishnan clearly wishes to capitalise on Ramana's reputation as one who has experienced the highest truth according to Hinduism - which according to Radhakrishnan followed the Advaita Vedānta system - to prove the ontological correctness and superiority of the Hindu tradition. The political agenda of Radhakrishnan can therefore be seen to deeply influence his representation of Ramana.

Prof. B. L. Atreya, Head of Dept. Philosophy, Benares Hindu University, also constructed Ramana as the embodiment of Advaita. Atreya

\footnotetext{
${ }^{67}$ Ibid., 113.

${ }^{68}$ S. Radhakrishnan, "Bhagavan Sri Ramana: Sustainer of Spiritual Reality" in Golden Jubilee Souvenir, 35.

${ }^{69}$ Ibid., 30. Italics mine.

70 Ibid., 29.

${ }^{71}$ Ibid. Italics mine.

72 Ibid., 32.
} 
asserted that Ramana's greatness lay in "his actual living by the creed of Advaita Vedānta." ${ }^{, 73}$ He then stated that

the greatest peculiarity and merit of Ramana Maharshi's life is that although he has moulded and perfected his personality on the lines of Advaita Vedānta, a purely Indian way of Self-realisation, he is highly appreciated and resorted to by Western seekers and by those Indians who have been educated on Western lines. ${ }^{74}$

There are two things to highlight in this statement: first, there appears to be a strategy of mutual validation, in which Atreya used Advaita to endorse Ramana, and also Ramana to vindicate Advaita. Second, Atreya emphasised Advaita as a uniquely Indian religious system, and importantly, one which had not been uniformly criticised by Westerners, but rather "appreciated". In this context, Atreya implied that Ramana played a significant role in winning this appreciation for Advaita. Atreya therefore promoted Ramana as a source of both Hindu pride and the vindication of Advaita Vedānta.

T. M. P. Mahadevan, Professor of Philosophy, Madras University, followed the trend evident in Radhakrishnan and Atreya. Typifying the highly romanticised rhetoric that Ramana seems to attract, Mahadevan described Ramana as "a sage without the least touch of worldliness, a saint of matchless purity, a witness to the eternal truth of Vedānta."75 The fact that Ramana routinely read the newspapers every morning is one example that highlights the exaggeration in Mahadevan's opening phrase. ${ }^{76}$ In this brief statement Mahadevan deracinates Ramana from all that does not pertain to the purely spiritual sphere, and uses him to testify to the correctness of Hinduism.

Mahadevan went on to categorise Ramana as an Advaitin, insisting that he "lived and taught" the "eternal message of Advaita Vedānta." 77 Like Radhakrishnan and Atreya, Mahadevan constructed Ramana as the embodiment of Hindu truth, claiming him to be "a living flame of God-realisation," and "a

\footnotetext{
${ }^{73}$ Arunachala's Ramana, vol. IV, 241.

${ }^{74}$ Ibid.

${ }^{75}$ Mahadevan, Bhagavan Ramana, 3.

${ }^{76}$ Osborne, Ramana Maharshi and the Path of Self-Knowledge, 146. Interestingly, Osborne stated that Ramana would often comment on particular items, before catching himself as follows: "though never in a way that could be taken as a political opinion."

${ }^{77}$ Ibid., 12.
} 
living commentary in the most sublime texts of the Vedānta." ${ }^{, 78}$ He concluded: "The Maharshi's teaching is exactly the same as that of the Upanișadic sage.",79 The ramifications of Mahadevan's last statement rely on the assumptions that the Upanișads represent the textual foundation of Vedānta, and Ramana's teaching confirmed the truth propounded in the Upanișads on the premise that his alleged "God-realisation" occurred without prior knowledge of these sacred texts. Further, Mahadevan echoed Orientalist assumptions of a pure, ahistorical, unchanging Hinduism, exemplified in the Upanișads. We can conclude that Mahadevan's agenda here, at least in part, was to present Ramana as a source of Hindu pride who had by his alleged spiritual attainments vindicated Advaita Vedānta, and thus Hinduism.

In sum, this section has revealed the various ways in which the context of nationalism can be applied to Ramana beyond the role of Ganapati Muni, and in doing so, illustrated the prominent place and value of the spiritual in nationalist discourse. We have seen that (1) early biographers of Ramana were closely involved in nationalist activities; (2) high profile political leaders celebrated Ramana's contribution to India and juxtaposed him with Gandhi, thus allowing him to assume the status of national hero; and (3) Hindu intellectuals, motivated by the desire to vindicate Hinduism and Advaita Vedānta, constructed Ramana as the living embodiment of Hindu truth, and importantly, as an Advaitin. These threads in unison again show that Ramana played a symbolic role during the nationalist era and that the colonial encounter shaped him in significant ways. Further, they indicate the extent to which Hindu spirituality was linked to national pride and the manner in which many Hindus conceived of national identity.

\subsection{Conclusion}

Expanding on the process that began with Ganapati Muni constructing Ramana as a Maharshi to serve his political agenda, which likewise ascribed Ramana a passive, symbolic role within a political context, this chapter has delineated Ramana's acquisition of the status of both national hero and Advaitin. This process constructed Ramana as the embodiment of a pan-Indian and orthodox

${ }^{78}$ T. M. P. Mahadevan, Arunachala Siva (Tiruvannamalai: Sri Ramanasramam, 2005), 115-16. Italics mine. These passages appeared in an article entitled "The Sage of Arunachala", which was published in the Indian Express, 9 April, 1950.

${ }^{79}$ Ibid., 119. 
Hinduism, an image which signifies a dramatic shift from his pre-Maharshi status as an unorthodox, localised Tamil Śaiva ascetic and devotee of Arunachala. Further, it shows that Ramana was important to and shaped by the forces of the colonial encounter and nationalism.

Just as Chapter One demonstrated the ways in which the dichotomy of East and West influenced representations of Ramana, the presence of Orientalism has again been seen in two significant ways: (1) in Brunton's Orientalist portrayal of Ramana as a timeless, ancient, otherworldly and purely spiritual figure; and (2) in the role of Orientalists in initiating a process of Vedanticisation, which fed into Ramana's categorisation as an Advaitin. Hindu leaders were involved in this process, which culminated in Advaita Vedānta emerging as a "nationalist ideology for uniting Hindus", as King asserted. We thus see an interesting dynamic at play in which both Westerners and Indians have collaborated in creating Ramana's image through Orientalist assumptions, an image that Indian nationalists utilised in an anti-British/imperial way. In this way, Hindu spirituality, or the purely spiritual, served as an anti-colonial weapon, responding to Vivekananda's cry for India to "conquer the world with her spirituality". Moreover, we see Orientalism functioning in contrast to Said's claim that European imperialism perpetuated Orientalism to dominate Asia. ${ }^{80}$

Ramana's status as a national hero has been reaffirmed in the decades after his passing. In 1980, Indian Prime Minister Indira Gandhi unveiled a statue of Ramana at his samadhi shrine (tomb) within Sri Ramanasramam. Such a gesture seems to resonate strongly with the sentiment that Ramana should be celebrated as a national treasure for having "won glory for India," as Aurobindo pronounced, and for his role as "a great unifying force in the life of modern India," as N. Chandrasekhara Iyer, former Judge of the Madras High Court, declared. ${ }^{81}$ Though his role during the liberation struggle may have been limited to a symbolic one, and although this contribution was greatly overshadowed by the likes of Gandhi and Nehru, for example, Ramana - as the Maharshi and living embodiment of Hindu truth - ought to be seen as an important figure in the context of modern India's most transformative period.

${ }^{80}$ Said, Orientalism, 3.

${ }^{81}$ N. Chandrasekhara Iyer, “A Unifying Force”, The Hindu, 16 April, 1950. 
The construction of Ramana as an Advaitin has made the strongest impression upon his popular image. In 1990, Prof. K. Swaminathan, famous for his role as chief editor of Gandhi's Collected Works, authored an article published in the Indian Express, in which he described Ramana as the embodiment of Advaita Vedānta truth, thus continuing the project that Radhakrishnan, Atreya and Mahadevan began in the 1940s. ${ }^{82}$ Scholars such as Thomas Forsthoefel and Arvind Sharma, on the other hand, have treated Ramana as an Advaitin, analysing his teachings within an ahistorical framework, ignoring the Vedanticisation of Hinduism, the role of Ganapati Muni, and nationalism in general.

In the remainder of this thesis, I contest Ramana's status as an Advaitin by referring to Ramana's comments on the subject, his written works and his relationship with Tamil Śaivism. I aim to show that if we analyse Ramana's life and teachings in an ahistorical way, and fail to recognise the presence of Orientalism, we misinterpret and misrepresent his significance in the development of modern Hinduism.

${ }^{82}$ K. Swaminathan, "Ramana Maharshi, the Greatest Teacher the World has seen", The Indian Express, 29 December, 1990. 


\section{Chapter Three}

\section{Framing Ramana's religious identity: Advaitin or Śaiva bhakta?}

\section{Introduction}

We have seen in Chapter Two the tendency of Hindu elites such as Radhakrishnan, Mahadevan, and Swaminathan to categorise Ramana explicitly as an Advaitin. This trend has been followed in scholarship on Ramana, as seen in Forsthoefel, Sharma and Fort. ${ }^{1}$ Forsthoefel goes as far as to describe Ramana's worldview as a "radical form of non-dualism." ${ }^{2}$ Wilhelm Halbfass, Gavin Flood and Richard King have treated Ramana, though briefly, in the same manner. Halbfass and Flood claim that Ramana's teachings are "pure Advaita," while King labels Ramana a "neo-Vedantin" and refers to him to succinctly explicate key points on Advaita doctrine. ${ }^{3}$

A limited reading of Ramana's works will certainly allow for the Advaitin label, as there is clear evidence of Ramana speaking in terms of nonduality. ${ }^{4}$ Additionally, Western devotees of Ramana such as Arthur Osborne and David Godman earnestly promote Ramana as an Advaitin. ${ }^{5}$ Importantly, both popular literature and scholarship on Ramana assumes that the non-duality that Ramana at times teaches has its origin in his alleged 'awakening' at sixteen, an event that both categories of literature emphasise on account of an apparent absence of a guru or doctrinal instruction.

What is striking, however, is that major works on Ramana released prior to the late 1930s, including those by Indians such as Ganapati Muni, Narasimha Swami and M. S. Kamath, on the one hand, ${ }^{6}$ and Westerners such as F. H. Humphreys and Paul Brunton, on the other, make no explicit mention of

\footnotetext{
${ }^{1}$ See, for example, Forsthoefel, Knowing Beyond Knowledge; Arvind Sharma, The Experiential Dimension of Advaita Vedanta (Delhi: Motilal Banarsidass, 1993); Fort, Jivanmukti in Transformation: Embodied Liberation in Advaita and Neo-Vedanta.

${ }^{2}$ Forsthoefel, Knowing Beyond Knowledge, 133.

${ }^{3}$ Wilhelm Halbfass, India and Europe, 384; Flood, An Introduction to Hinduism, 271; Richard King, Indian Philosophy: an Introduction to Hindu and Buddhist Thought (Washington D. C: Georgetown University Press, 1999), 215.

${ }^{4}$ See Ramana Maharshi, Who Am I?: The Teachings of Bhagavan Sri Ramana Maharshi (Tiruvannamalai: Sri Ramanasramam, 2007), 11-12.

${ }^{5}$ See, for example, Osborne, Ramana Maharshi and the Path of Self-Knowledge, 87; Godman, Be As You Are, 67.

${ }^{6}$ See Vasishtha Ganapati Muni, Śrī Ramaṇa Gìtā, trans. by K. Swaminathan (Tiruvannamalai: Sri Ramanasramam, 2004); Narasimha Swami, Self Realization; Kamath, My Motherland; M. S. Kamath, Sri Ramana Maharshi: a Biography with 111 Illustrations (Madras: The Sunday Times Bookshop, 1936).
} 
Advaita. ${ }^{7}$ Moreover, I show that Ramana never explicitly labels himself an Advaitin.

While I acknowledge that several of Ramana's ontological assertions are compatible with Advaita Vedānta, I claim that the details of his religiosity are not exclusively and definitively compatible to Advaita Vedānta. This chapter therefore argues that Ramana's categorisation as an Advaitin is more dependent upon the fruits of Orientalism, Hindu reform and certain political needs of the colonial period, than on his alleged 'awakening'. I further argue that Ramana's ontological and soteriological teachings correspond to inclusivism. By 'inclusivism', I am referring to the practice of affirming and conflating multiple religious systems, despite the fact that they contain distinct and at times sharply contrasting worldviews. In this context, Ramana's teachings are compatible with ideologies pertinent to the construction of Hinduism during the colonial period. ${ }^{8}$ After discarding the Advaitin label, I claim that Ramana ought to be primarily identified with the Tamil Śaiva bhakti tradition.

I will support these claims on the following grounds: (1) Ramana never explicitly affirmed himself as an Advaitin when presented with the opportunity; (2) Ramana's various references to his 'awakening' reveal tensions with the ontology of Advaita; (3) Ramana's ontology and soteriology are never exclusively Advaitin but rather inclusivistic; (4) the Tamil Śaiva bhakti tradition was the one religious constant throughout his life, particularly in terms of praxis, as most prominently seen in his devotional relationship to Arunachala. These points demonstrate that Ramana's categorisation as an Advaitin was an elitist construct and heavily influenced by the colonial encounter, thus further cementing Ramana's footing in the historical period in which he lived.

\footnotetext{
${ }^{7}$ Brunton, A Search in Secret India; Frank H. Humphreys, Glimpses of the Life and Teachings of Bhagavan Sri Ramana Maharshi (Tiruvannamalai: Sri Ramanasramam, 1999). This work was originally published in the International Psychic Gazette, May, June, July 1913.

${ }^{8}$ See Paul Hacker, "Aspects of Neo-Hinduism as Contrasted with Surviving Traditional Hinduism," in Philology and Confrontation: Paul Hacker on Traditional and Modern Vedanta, ed. Wilhelm Halbfass (Albany: State University of New York Press, 1995), 244-45; Halbfass, India and Europe, 401-418.
} 


\section{Advaita Vedānta and Indian philosophy}

Traditionally, Vedānta has been ascribed a single place in the six major Indian/Hindu schools of philosophy (saddarśana). ${ }^{9}$ While there are numerous Vedānta traditions, Advaita Vedānta is one of three major sub-schools; the other two are Viśiștạadvaita (qualified non-dualism) and Dvaita (dualism). The Upanișads, the Brahma Sütra and the Bhagavad Gìtà make up the major authoritative texts of the Vedānta tradition as a whole. The distinct sub-schools of Vedānta are distinguished by the commentaries (bhāṣya) on these authoritative texts by their respective founders: Śankara (eight century CE) in the case of Advaita; Rāmānuja (1017-1137) in the case of Viśișțādvaita; and Madhva (1238$1371)$ in the case of Dvaita. ${ }^{10}$

The Advaita (literally, 'not-two') tradition of Śankara postulates an ontology of non-dualism, which succinctly put, means that the supreme transcendental principle, brahman, is all that is real, and further, that there is no difference between brahman and the self, ätman. Śankara characterises brahman as formless, without qualities (nirguna), unchanging and ineffable. The world, plurality and conceptions of the individual as a separate and distinct entity are illusory $(m \bar{a} y \bar{a})$, and arise on account of ignorance (avidya $)$, i.e. the failure to realise the identity of ätman with brahman. To overcome this state of ignorance and obtain mokṣa (spiritual liberation), Śankara emphasises jñ̄nna mārga (the path of knowledge), and relegates bhakti mārga (the path of devotion) as a useful, but inferior soteriology. ${ }^{11}$

While Śaṅkara's radical non-dualism distinguishes Advaita from other sub-schools of Vedānta, it is not the only non-dualist school in the context of Indian/Hindu thought: others include; the Śabdādvaita of the grammarian Bhartṛhari, the Pratyabhijñā school of Kashmir Śaivism, and a devotional variety found in the Bhagavatā Purāna. ${ }^{12}$ Yet what distinguishes Śankara's Advaita from these other schools, particularly in the context of the colonial encounter, is the

\footnotetext{
${ }^{9}$ The others are; Nyāya - the School of Logic; Vaiśeșika - the School of Atomism; Sāṃkhya - the School of Enumeration, or dualistic Discrimination; Yoga - the School of Classical Yoga; Mīmāmsāa - the School of Vedic Exegesis.

${ }^{10}$ King, Indian Philosophy, 53-57; Flood, An Introduction to Hinduism, 238-39; Sarvepalli Radhakrishnan and Charles A. Moore, ed., A Source Book in Indian Philosophy (Princeton: Princeton University Press, 1957), 506-509.

${ }^{11}$ Radhakrishnan and Moore, eds., A Source Book in Indian Philosophy, 509-542; King, Indian Philosophy, 54-56, 213-21; Flood, An Introduction to Hinduism, 239-41.

${ }^{12}$ King, Indian Philosophy, 55.
} 
prestigious position as the orthodox doctrine of a single, homogenous Hinduism that it was assigned by key Hindu reformers and nationalist leaders. Given the important role that Hinduism played in nationalist discourse, and particularly in the unification process, Advaita Vedānta therefore came to represent a potent symbol geared towards nationalist objectives. ${ }^{13}$ Ramana's standing as an Advaitin is certainly embedded in this historical situation.

\section{1. "Others find that it tallies with Śri Śankara"}

This section focuses on (1) Ramana's response to questions posed about the precise nature of his ontological position, i.e. whether or not he is an Advaitin, and (2) Ramana's various accounts of his 'awakening' at sixteen. In the former, Ramana neither explicitly denied nor affirmed that his teachings follow Śankara or Advaita Vedānta, but instead insisted that his teachings derive from his own experience. In the latter, Ramana described his alleged 'awakening' in ways that are not exclusively and definitively compatible with Advaita. Instead we see a transformative experience in which Ramana simply and broadly concludes that he is 'not the body', with additional references to an abstract 'force', 'current' or 'energy'. We are not, however, confronted with claims concerning a realisation in which the individual experienced his own essence, i.e. àtman, as identical with a transcendental absolute, i.e. brahman.

\subsubsection{Does Ramana call himself an Advaitin?}

Here I give three examples of Ramana neither explicitly denying, nor affirming that his teachings follow Advaita. There are two things at stake here. First, as Ramana never actively categorised himself as an Advaitin (nor does literature on Ramana released prior to the late 1930s), the agendas of Hindu intellectuals and scholars who constructed him as such ought to be investigated. Second, Ramana's reluctance to label himself an Advaitin supports the claim that his position is actually inclusivist (see section 3.2).

Devaraja Mudaliar provides the first example of Ramana refraining from characterising himself as an Advaitin. In March 1946, Ramana received a letter which included the following: "Ramana Maharshi is an exponent of the

${ }^{13}$ King, Orientalism and Religion, 135; King, Indian Philosophy, 42. 
Ajāta doctrine of Advaita Vedānta." Ramana replied: "Somebody has told him so. I do not teach only the Ajāta doctrine. I approve of all schools." ${ }^{14}$ There are two things to underline here. First, Ramana makes it clear that the letter's author has assumed that he teaches the ajāta doctrine of Advaita on account of a third party promoting him as such. Second, we see clear evidence of Ramana speaking in inclusivistic terms. While the phrase, "I approve of all schools", may allow for an alternative interpretation in this context, i.e. Ramana meant that he approves of all schools of 'Advaita', I present evidence below that supports Ramana's tendency toward inclusivism.

The second example illustrates a clear opportunity for Ramana to categorise himself as an Advaitin. M. S. Venkataramiah's account of an exchange between Ramana and Mr Thomas, a professor of Sanskrit at Oxford, ${ }^{15}$ again reveals Ramana's reluctance to label himself an Advaitin. Mr Thomas' clear inquiry into whether Ramana "advocated Advaita" was met with the following response: "Dvaita (duality) and advaita (non-duality) are relative terms. They are based on the sense of duality. The Self is as it is. There is neither dvaita nor advaita." $" 16$ The ambiguity notwithstanding, once again Ramana avoided affirming his status as an Advaitin when presented with the opportunity. Further, Ramana's response indicates that Advaita - as the most prestigious worldview of Hinduism, or as a cultural symbol imbued with a nationalistic impulse - was not as important to him as it was to figures such as Radhakrishnan and Mahadevan.

The third example consists of Ramana's exchange with Oliver Lacombe. Here we also see Ramana asserting that his teachings are founded on the authority of his own realisation, as opposed to a specific tradition. Lacombe's inquiry as to whether Ramana's teaching followed Śankara's elicited the following response: "Maharshi's teaching is only an expression of his own experience and realisation. Others find that it tallies with Śrī Śankara's." ${ }^{17}$ Again presented with the opportunity to declare his allegiance to Advaita, Ramana chose to distance

\footnotetext{
${ }^{14}$ Mudaliar, Day by Day with Bhagavan, 174-75.

15 A. J. Arberry, "Thomas, Frederick William (1867-1956)," in J. B. Katz, Oxford Dictionary of National Biography (Oxford: Oxford University Press, 2004), http://www.oxforddnb.com/view/article/36472 (accessed 10 Aug 2011)

${ }^{16}$ Venkataramiah, Talks with Sri Ramana Maharshi, 417-18.

${ }^{17}$ Ibid., 160. Italics mine. Note that Ramana referred to himself in the third person, usually as 'Bhagavan', but in this instance as 'Maharshi' because Lacombe had addressed him as such.
} 
himself from it. Moreover, Ramana asserted that it is "others" whom claim his teachings conform to Advaita and not himself.

In addition, I surmise that Ramana was precisely aware of that which constitutes Advaita Vedānta and qualifies one as an Advaitin. Advaita Vedānta consists of far more than non-dualism. Even Forsthoefel is aware of and clear on this point, despite the fact that he continues to categorise Ramana as an Advaitin:

it is probably misguided to identify Ramana as an 'Advaitin' at all, since Advaita represents an entire cultural and institutional matrix that minimally consists of text, tradition, and teacher; all of these in turn constitute a kind of 'external' circuitry, that is, a complex set of socially established doxastic mechanisms which inform and shape traditional Advaitin programs of liberation and their subsequent verbal outcomes. ${ }^{18}$

It is precisely the 'external circuitry' that Forsthoefel is concerned with here, as it represents the antithesis of his treatment of Ramana. In this context, identifying Ramana as an Advaitin would mean that his brand of non-duality belonged to the distinct "social and cultural settings of South Asia,"19 to use Forsthoefel's phrase, which would render problematic his thesis that Ramana "liberates Advaita from its local context." ${ }^{20}$ Conversely, if Forsthoefel were to discard the Advaitin label, it would render problematic his method of comparing Ramana's "internalism" to Śankara's "externalism", and again disturb the foundations of his thesis. The paradox is obvious - Forsthoefel needs the Advaita label but not the contextual baggage that comes with it. Nonetheless, Ramana would have been keenly aware of the "entire cultural and institutional matrix" and "complex set of socially established doxastic mechanisms" that comprise the Advaita Vedānta tradition, to which, of course, he did not conform, and hence the reluctance to categorise himself as an Advaitin.

The three examples delineated above presented Ramana with occasion to categorise himself an Advaitin. While he did not explicitly deny the Advaita label, he did not provide any evidence that categorically asserted the wish to be labelled an Advaitin. This suggests that Ramana's status as an Advaitin was more

\footnotetext{
${ }^{18}$ Forsthoefel, "Weaving the Inward Thread to Awakening: the Perennial Appeal of Ramana Maharshi”, 244.

${ }^{19}$ Ibid., 155.

${ }^{20}$ Forsthoefel, Knowing Beyond Knowledge, 124.
} 
important to others, such as Radhakrishnan, Mahadevan and Osborne, than it was to himself. Conversely, one might query whether any Advaitin would proclaim himself as such, on the grounds that Advaita holds that there are no individuals, no 'Advaitins', there is only brahman. The evidence presented in this section, however, should not be taken in isolation, but rather as one part of a greater sum. In fact, in Ramana's responses, we have seen two themes I further explore: the claim that his teachings derive from his 'awakening' experience at sixteen, which follows immediately below, and the inclusivistic sentiment found in his comment that he "approves of all schools" (section 3.2.).

\subsection{2. "The consciousness of individuality was very much there"}

Ramana's various references to his 'awakening' further challenge the accuracy of those who construct him as an Advaitin. We have seen in Ramana's response to Lacombe that Ramana held his "own experience and realisation" to be the authoritative source of his teachings. Ramana implied here that his initial transformative experience at sixteen defined his ontology and soteriology. The importance of this event may also be seen in Balarama Reddy and Osborne, who insisted that Ramana "declared explicitly and a number of times that there was absolutely no change or development in his state of consciousness or spiritual experience [after the initial experience at sixteen]." ${ }^{21}$ This means that Ramana held that his alleged 'awakening' at sixteen initiated a sustained spiritual state that remained unchanged throughout the rest of his life. As I will show, several of Ramana's descriptions of his 'awakening' are contrary to non-dualism. These descriptions therefore contest a non-dualistic reading of the experience, and further, those who mark this occasion as the definitive source of his supposed non-dualism.

The accounts that follow demonstrate that there is no evidence to affirm that Ramana's 'awakening' corresponds exclusively to Advaita. Rather, we see that these accounts are compatible with diverse Hindu metaphysical schools, including the dualistic Sāmphya, for example, which holds that there are two fundamental ontological categories, purușa (pure spirit or consciousness) and prakrti (matter or nature), and which does not propound that this world is illusory,

${ }^{21}$ Osborne, Ramana Maharshi and the Path of Self-Knowledge, 26; Balarama Reddy, My Reminiscences, 65. 
as is the case with Advaita. Additionally, Sāmpkhya holds that puruṣas are pluralistic, which stands in sharp contrast to the monistic brahman of Advaita. ${ }^{22}$ Succinctly put, Ramana's alleged 'awakening' meant realising that his true identity was not the body. Instead Ramana interpreted his true identity as an abstract entity he ambiguously described as a type of energy, power, force or current.

Ramana claimed that a sudden fear of death provoked him to enact the process of death. He claimed that during this process he inquired inwardly into the nature of death and what it meant for the body to die. Ramana concluded that he was not the body, but rather something transcending the body. ${ }^{23}$ The first published account of Ramana's alleged 'awakening' is contained in Narasimha's Self Realization. Reflecting on the event circa 1929-30 (i.e. 33-34 years after it occurred), Ramana stated:

And I at once dramatised the occurrence of death. 'Well then,' I said to myself, 'this body is dead...But with the death of this body am I dead? Is the body 'I'? It is silent and inert but I feel the full force of my personality and even the voice of the 'I' within me, apart from it. So I am Spirit transcending the body. The body dies but the Spirit that transcends it cannot be touched by death. That means I am the deathless Spirit. ${ }^{24}$

This account clearly presents Ramana discerning his true identity as "not the body', but rather as an intangible and abstract entity that survives the death of the body. It is not clear, however, that Ramana had realised the existence of a nondual substratum without beginning or end, or that the phenomenal world is nothing more than a mere illusion, both of which are basic features of Advaita. ${ }^{25}$ Further, Narasimha's use of "Spirit" (the work was originally written in English) creates enough ambiguity to allow for diverse interpretations, such as brahman, on the one hand, and an individual soul, or purusa, on the other.

Additionally, there are striking similarities in this account with Vivekananda's 1893 'Chicago Speech', which raise several interesting issues:

22 See King, Indian Philosophy, 62-67; and Gerald James Larson, Classical Sāṃhya: an Interpretation of its History and Meaning (Delhi: Motilal Banarsidass, 2001), 7-14.

${ }^{23}$ Narasimha Swami, Self Realization, 17-18.

${ }^{24}$ Ibid. This account is also used by Osborne. See Osborne, Ramana Maharshi and the Path of Self-Knowledge, 8-9.

${ }^{25}$ King, Indian Philosophy, 54-55. 
Here I stand and if I shut my eyes and try to conceive my existence, 'I', 'I', 'I', what is the idea before me? The idea of a body. Am I, then, nothing but a combination of material substances? The Vedas declare 'No'. I am a Spirit living in a body. I am not the body. The body will die, but I shall not die. Here am I in this body; it will fall, but I shall go on living. ${ }^{26}$

The similarities may be immediately seen with the use of 'I' and 'Spirit', and the claim that the 'I' is 'not the body'. But perhaps the most striking similarity lay in Ramana's "I am Spirit transcending the body," and Vivekananda's "I am a Spirit living in a body." Two pieces of evidence make these similarities compelling: first, Ramana possessed a copy of Vivekananda's 'Chicago Speech' prior to his alleged 'awakening'. ${ }^{27}$ Second, Narasimha translated the life and sayings of Vivekananda into Tamil during the same period he was staying at Sri Ramanasramam researching for and writing Self Realization. ${ }^{28}$

It is possible that both of these points are behind the similarities, but I surmise that it is more plausible that the similarities are contingent upon Narasimha's English rendering of his Tamil interview with Ramana. The historical importance of Vivekananda's 'Chicago Speech' may have influenced Narasimha to make Ramana's account more compatible to Vivekananda's celebrated and 'orthodox' account. If this is the case, then it would be ill-advised to rely solely on this account, even more so when other accounts contain provocative details omitted in this one.

Sri Ramana Leela, the Telugu biography which Ramana had himself proofed, gives an alternative account of Ramana's 'awakening'. ${ }^{29}$ Ramana stated: "Even if the body died, the sense of 'I' did not go. The consciousness of individuality was very much there. When the body was taken to the graveyard and reduced to ashes 'I' did not perish because 'I' was not the body." ${ }^{30}$ Here we again see Ramana denying the body as the seat of his identity, yet on this occasion a provocative detail arises that strikes at the heart of the ontology of Advaita. Ramana asserted that he was still aware of his individuality, rather than speaking

${ }^{26}$ Swami Vivekananda, Selections from Swami Vivekananda, 5-6. Note that this speech was delivered in English, thus it is reproduced here in its original form.

${ }^{27}$ Arunachala's Ramana, vol. I, 55.

${ }^{28}$ Narasimha Swami, Self Realization, 204.

${ }^{29}$ See above.

${ }^{30}$ Bhikshu, Sri Ramana Leela, 18. Italics mine. 
in terms of its dissolution. Further, this assertion corresponds more closely to dualistic ontologies such as Dvaita Vedānta, Sāṃkhya and the Classical Yoga School, in which the self, or the individual's eternal 'spiritual essence', is distinct and separate from other 'real' ontological principles, whether in the form of a monotheistic god or prakrti (matter/nature). ${ }^{31}$ Thus, in this account we see further tensions between Ramana's 'awakening' and the ontology of Advaita.

The following example further heightens these tensions and strongly contests the assumption that Ramana's alleged 'awakening' corresponded exclusively to Advaita. Ramana confessed:

Even in the beginning I realised that I am not the body. After I came to Arunachala all sorts of questions cropped up, whether I am one with the all-pervading Reality or different, whether that Reality is non-dualism (advaita), dualism (dvaita) or qualified non-dualism (vishishtadvaita) etc. ${ }^{32}$

The phrase 'I am not the body' is present once more, but here we encounter Ramana admitting that his transformative experience failed to draw an ontological conclusion on the relationship between his assumed true identity and absolute reality. I wish to further stress the phrase "questions cropped up" after he arrived at Arunachala, i.e. at least two months after his alleged 'awakening'. This evidence sufficiently demarcates the boundaries of Ramana's transformative experience, in that he arrived at no additional conviction beyond the idea that his true identity was 'not the body'. Therefore, Ramana's 'awakening' cannot be said to tally definitively with the Advaita tradition.

In addition to Ramana's realisation that he was 'not the body', further accounts reveal an extra quality in Ramana's 'awakening', which interestingly does not feature in the account used by Osborne and Narasimha. Ramana stated on several different occasions that he experienced a type of 'force', 'power', 'energy' or 'current' in his 'awakening', which thoroughly transformed him. Ramana said:

When I lay down with limbs outstretched and mentally enacted the death scene and realised that the body would be taken and

${ }^{31}$ See King, Indian Philosophy, 57, 62-73.

${ }^{32}$ Arunachala's Ramana, vol. I, 129-30. 
cremated and yet I would live, some force, call it atmic power or anything else, rose within me and took possession of me. With that, I was reborn and I became a new man. ${ }^{33}$

Viswanathan Swami corroborates this detail, recalling Ramana's description of his 'awakening' as follows: "Some mysterious power took possession of me and affected a thorough transformation." 34

On yet another occasion, Ramana stated: "I felt that there was a force or current, a centre of energy playing on the body continuing, regardless of the rigidity or activity of the body, though existing in connection with it...From that time on, I was spending my time absorbed in contemplation of that current.",35 Ramana went on to say: "I had no idea at that time of the identity of that current with the personal God or 'Iswara' as I used to call him." ${ }^{36}$ The terms employed in these accounts, i.e. 'current', 'force', appears to capture a more personal and direct reflection on the nature of his transformative experience, rather than the construction of it in terms of an orthodox and universalised terminology, such as 'the Self' or 'the Spirit'. There is also something more unique and original - and even more interesting - in the descriptions that speak of a current or energy, as opposed to yet another voice proclaiming non-duality. Scholarship on Ramana has certainly failed to notice this detail and has simply sung in the chorus of his nondualism. In my view, scholars have thus overlooked something far more intriguing and provocative.

In sum, this section has presented several examples of Ramana neither explicitly denying nor affirming himself to be an Advaitin. Ramana's reluctance to explicitly categorise himself as such raises ample doubts about the accuracy of the Advaitin label. Ramana's status as an Advaitin was further challenged by our analysis of various accounts of the nature of his alleged 'awakening'. This analysis demonstrated that Ramana simply conceived of his transformative experience as the realisation that the seat of his true identity lay not in the body, but rather in an abstract transcendental entity he described as a type of force,

\footnotetext{
${ }^{33}$ Mudaliar, Day By Day with Sri Bhagavan, 48. Italics mine.

${ }^{34}$ Arunachala's Ramana, vol. I, 570. Italics mine.

${ }^{35}$ Ibid., 55. Italics mine.

${ }^{36}$ Ibid. Italics mine. On another occasion still, Ramana asserts: "I was only feeling that everything was being done by the current and not by me...I had ceased to regard the current as my narrow 'I'. That current or avesam now felt as if it was myself- not a superimposition." See Arunachala's Ramana, vol.1 67.
} 
current, energy or power. Importantly, we fail to see any evidence in these accounts which definitively and explicitly corresponds to Advaitin ontology. We see instead descriptions that are compatible with diverse Hindu metaphysical schools, including dualistic ontologies. This broad scope resonates strongly with an inclusivistic ontology and soteriology, of which we saw evidence in Ramana's assertion that he "approves of all schools." I now turn to investigating this theme further.

\section{2. "All these different mārgas or sādhanas lead to the same goal"}

Maharshi is regarded by many as a sphynx...Śaktas go to him and think he is a Śakta, Śaivas take him for a Śaiva: Śrivaișnavas find nothing in him inconsistent with their Viśiștādvaitic ideal. Moslems and Christians have found in him elements of their 'true faith. ${ }^{37}$ (Narasimha Swami, Self Realization)

This section continues to critique the accuracy of characterisations of Ramana as an Advaitin by further examining his inclusivism. I argue that Ramana's ontology and soteriology are better framed as inclusivistic, rather than exclusively Advaitin. To support this claim I present evidence that Ramana (1) affirmed the practice of diverse Hindu soteriological strategies; (2) conflated different ontologies within Hinduism; and (3) applied a universalising or perennialist reading of sacred texts such as the Bhagavad Gìtā and the Bible.

Both Ramana's inclusivism and his tendency to universalise doctrines from diverse religious traditions reflect key trends in neo-Hindu thinking during the colonial period. ${ }^{38}$ The contributions of Ramakrishna (of whom there was a portrait in the main hall of Ramana's ashram ${ }^{39}$ ) and Vivekananda are particularly notable, the latter especially so. Vivekananda's reform project promoted universal principles and an inclusivistic approach, which aimed to advocate the superiority of Hinduism on the premise of its alleged attitude of religious 'tolerance'. ${ }^{40}$

\footnotetext{
${ }^{37}$ Narasimha Swami, Self Realization, 210.

${ }^{38}$ Hacker, "Aspects of Neo-Hinduism as Contrasted with Surviving Traditional Hinduism", 24445; Halbfass, India and Europe, 401-418; King, Orientalism and Religion, 105.

${ }^{39}$ Osborne, Ramana Maharshi and the Path of Self-Knowledge, 164.

40 Vivekananda, Collected Works, vol. I, 3; Tapan Raychaudhuri, "Swami Vivekananda's Construction of Hinduism," 8-9; King, Orientalism and Religion, 140; Halbfass, India and Europe, 228-29, 408-09; Bandyopadhyay, From Plassey to Partition, 236.
} 
Moreover, Vivekananda's project was driven by a nationalistic impulse. ${ }^{41}$ This impulse in turn influenced nationalist discourse, as Chowdhury-Sengupta asserts: "Vivekananda's construction of Hinduism in universalist terms gave the emerging nationalist discourse much of its force and direction." ${ }^{42}$ In the context of advocating inclusivism and universalism, Ramana, then, both echoed and contributed to the process of homogenising the complex diversity of Hindu religiosity during the colonial period, in which the aim was to present a single religion that would aid nationalism and the unification process. This point further contests ahistorical representations of Ramana in recent scholarly literature, notably that of David Kinsley, who claimed that Ramana's "teachings have an air of timeless, classic structure. They seem as appropriate to twentieth century Hinduism as they do to first century Hinduism." 43

Ramana's stance that he "approves of all schools" arose again in conversation with Dilip Kumar Roy. Ramana affirmed that he perceived no contradiction between bhakti mārga (the path of devotion) and jūanna mārga (the path of knowledge), claiming that these dissimilar soteriologies "are one and the same." ${ }^{44}$ Ramana elaborated: "Only different thinkers have used different words. All these different mārgas or sädhanas lead to the same goal." $" 45$

On a separate occasion, Ramana asserted that he "does not criticise any of the existing methods. All are good for the purification of the mind." ${ }^{46}$ This sentiment - that the diverse and various spiritual paths and practices found within Hinduism are all equally effective - intimately echoes representations of important figures such as Ramakrishna, ${ }^{47}$ and clearly demonstrates Ramana promoting a soteriological inclusivism.

\footnotetext{
${ }^{41}$ Hacker, "Aspects of Neo-Hinduism as Contrasted with Surviving Traditional Hinduism," 233, 240-41; van der Veer, Imperial Encounters, 47-48; Flood, An Introduction to Hinduism, 259.

${ }^{42}$ Indira Chowdhury-Sengupta, "Reconstructing Hinduism," in Swami Vivekananda and the Modernization of Hinduism, ed. William Radice (New York: Oxford University Press, 1998), 28.

${ }^{43}$ Kinsley, Hinduism: a Cultural Perspective, 46. Emphasis mine. Another point of similarity between Ramana and Vivekananda, which further connects him to the colonial period, was their acceptance of making the teachings of Advaita Vedānta available to all, as opposed to restricting them to the exclusive property of male brahmans, which was the case with Śnikara. In fact, Vivekananda was critical of Śankara on this matter. See Raychaudhuri, "Swami Vivekananda's Construction of Hinduism", 14.

${ }^{44}$ Venkataramiah, Talks with Sri Ramana Maharshi, 118, 240.

${ }^{45}$ Mudaliar, Day by Day with Bhagavan, 177.

${ }^{46}$ Venkataramiah, Talks with Sri Ramana Maharshi, 160.

${ }^{47}$ Flood, An Introduction to Hinduism, 257.
} 
To Ramana, the suitability of a specific practice depends largely on "temperament," 48 a point which again strongly echoes Ramakrishna. ${ }^{49}$ In addition to endorsing the path of knowledge and the path of devotion as means to attain liberation, Ramana also affirmed the effectiveness of "Tantrik sādhana" and "Tantra worship", 50 the practice of japa (reciting mantras or the names of deities), ${ }^{51}$ ișta-devatā (chosen deity) and gurus, which he states are "very powerful aids, ${ }^{, 52}$ and diverse forms of yoga. ${ }^{53}$

Textual evidence for this last point may be found in Ganapati Muni's Śrì Ramaṇa Gìtā ${ }^{54}$ Ganapati described Śrī Ramaṇa Gìtā as one dealing with yoga, asserting that "the secrets of mantra yoga, rāja yoga, jũāna yoga and bhakti yoga have been ably revealed here." ${ }^{, 55}$ Ganapati concluded: "an earnest study of this work will truly give one the clear knowledge of the path of yoga." ${ }^{, 56}$ Importantly, Ganapati did not categorise the work as belonging to Advaita, or even Vedānta; rather he clearly saw it as including and reconciling different paths of yoga. $S r \bar{r}$ Ramaṇa Gìtà equally emphasises mantra, Tantra, meditation, knowledge and devotion. There is no evidence in this work to suggest that Ramana's teachings are exclusively Advaitin. Rather, we see further evidence of inclusivism.

This theme carries over into one of Ramana's original compositions, Upadeśa Sāram. In verse ten of Upadeśa Sāram (The Essence of Instruction), Ramana attempts to reconcile four separate sādhanas or mārgas, i.e. jūāna (knowledge), bhakti (devotion), karma (action) and yoga (union), explaining that they will all lead to "Absorption in the Heart." ${ }^{57}$ Upadeśa Sāram endorses a variety of soteriological strategies, such as "worship", singing "hymns of praise," and meditation. ${ }^{58}$ Ramana's soteriological inclusivism is therefore again evident. Yet these diverse and distinct soteriological strategies entail diverse and distinct

\footnotetext{
${ }^{48}$ Venkataramiah, Talks with Sri Ramana Maharshi, 250.

${ }^{49}$ Flood, An Introduction to Hinduism, 257.

${ }^{50}$ Venkataramiah, Talks with Sri Ramana Maharshi, 250

51 Ibid., 61.

52 Ibid., 30.

${ }^{53}$ Ibid., 43-44.

${ }^{54}$ Vasișțha Ganapati Muni, Śrī Ramaṇa Gìtā. This work was composed in 1917, and represents the first in depth account of Ramana's teachings. Śr Ramaṇa Gìtā is modelled on the structure of the Bhagavad Gìtā, which highlights the central position yoga takes in the work. The conclusion of each chapter describes Śrī Ramana Gìtā as "the science of Brahman and the scripture of Yoga."

55 Ibid., vii.

${ }^{56}$ Ibid., ix.

${ }^{57}$ Ramana Maharshi, "Upadeśa Sāram," in The Collected Works of Sri Ramana Maharshi, ed. Arthur Osborne (Tiruvannamalai: Sri Ramanasramam, 2005), 111.

${ }^{58}$ Ibid., 109-10.
} 
ontological paradigms such as the dualism that bhakti and yoga require, in addition to the non-dualism of the jūanna in Advaita. I suggest that Ramana attempted to reconcile this problem by conflating different Hindu metaphysical systems, and as a result, he expounded an inclusivistic brand of ontology.

Expanding on the theme that he found no contradiction between jūāna and bhakti as soteriological strategies, Ramana attempted to reconcile their conflicting ontological paradigms by contending that "the Self of the Advaitins is the God of the bhaktas." ${ }^{59}$ On a separate occasion Ramana emphasised that there "is no difference" between the personal god (İ́vara) found in bhakti and "the Absolute" found in Vedānta. ${ }^{60}$

But perhaps the most provocative example in this context lay in Ramana's response to Professor Syed Hafiz's inquiry into the possibility of reconciling Vaishnavism (the sect pertaining to the worship of Vishnu) and Advaita. Ramana replied: “The Vaishnavites call themselves Viśișțādvaitins. This is also Advaita." ${ }^{61}$ On another occasion Ramana affirmed that Viśiștādvaita corresponded to his own teachings. ${ }^{62}$ Apart from the obvious sectarian differences between the two systems, there are distinct and important ontological and soteriological differences. In brief, Śankkara's Advaita stresses jñ̄ana over bhakti (the latter seen as less advanced), along with a formless absolute without attributes or qualities (nirguṇa brahman). Rāmānuja strongly criticised Śañkara's stance, and interpreted Vedānta as Viśișțādvaita (qualified non-dualism), emphasising bhakti and interpreting the absolute as a personal creator with qualities (saguna brahman). ${ }^{63}$ In short, Advaita simply is not Viśsisțādvaita. Ramana's strategy of overlooking these differences indicates an attitude of ontological inclusivism.

This approach extends to his reading of major religious traditions such as Christianity and Buddhism. On the several occasions that Ramana is recorded as quoting from or referring to the Bible, he emphasised a universal connection between Christianity and Hinduism. According to Ramana, Vedānta is contained in two Biblical statements: "I am that I am" (Exodus 3:14) and "Be still and know

\footnotetext{
${ }^{59}$ Venkataramiah, Talks with Sri Ramana Maharshi, 240.

${ }^{60}$ Ibid., 153.

61 Ibid., 239.

${ }^{62}$ Ibid., 146.

${ }^{63}$ See King, Indian Philosophy, 221-28.
} 
that I am God" (Psalm 46:10). ${ }^{64}$ Both phrases have been taken out of context. To claim that certain points in Judaism follow the speculative philosophy of the Upanișads and vice versa indicates the kind of inclusivistic and universalist interpretation one would likely find in perennial philosophy.

Ramana also asserted that "the Bible and the Gìtā are the same.",65 Again, the differences between the two sacred texts are far greater than any minor similarities they may coincidentally contain. Perhaps the clearest example of Ramana conflating the theologies of Hinduism and Christianity lay in the following:

O Arjuna, I am in the expanse of the Heart," says Sri Krishna. "He who is in the sun, is also in this man", says a mantra in the Upanishads. "The Kingdom of God is within", says the Bible. All are thus agreed that God is within. ${ }^{66}$

To suggest that the Bhagavad Gitā, the Upanișads and the Bible all propound the same theology of immanence clearly results from a selective reading and a universalising agenda befitting of inclusivism. Ramana attempted to achieve a similar result when he declared that the noble eight-fold path of Buddhism is the same as "the Rāja Yoga of the Hindus". ${ }^{67}$ While there may be some similarities, they are superficial and the differences are far greater.

In sum, I have further contested in this section the validity and accuracy of Ramana's categorisation as an Advaitin. The evidence has demonstrated that Ramana's ontology and soteriology are better framed as inclusivistic, rather than exclusively Advaitin. We have seen Ramana affirm the effectiveness of diverse and distinct soteriological strategies in verbal exchanges and textual sources, which then required the conflation of conflicting ontological paradigms such as non-dualism, qualified non-dualism and dualism.

In addition, Ramana's inclusivism included a universalising approach in his reading of Hinduism and other religious traditions, such as Christianity and Buddhism. In this context, Ramana strongly reflected the reformist agenda of

\footnotetext{
${ }^{64}$ Venkataramiah, Talks with Sri Ramana Maharshi, 319. Note that 'I am who I am' appears in the NRSV Bible. See New Revised Standard Version Bible (Grand Rapids, Michigan: Zondervan, 1991).

${ }^{65}$ Ibid., 144.

${ }^{66}$ Ibid., 174.

${ }^{67}$ Ibid., 19.
} 
Vivekananda, with which Ramana had been familiar prior to his 'awakening', and again in more detail in the years after his arrival in Tiruvannamalai. ${ }^{68}$ Ramana, then, both echoed and contributed to the process of homogenising the complex diversity of Hindu religiosity during the colonial period, which further undermines ahistorical representations.

\subsection{Orientalism, textual bias and Vedanticisation}

We have seen in previous chapters that Orientalist stereotypes concerning a mystical East shaped representations of Ramana. Paul Brunton, hagiographers and even scholars such as Kinsley, Sharma and Forsthoefel have typically presented Ramana as purely spiritual, ancient and timeless. In addition to these assumptions, two additional legacies of Orientalism have carried over into recent scholarship on Ramana, affecting the ways that he has been interpreted and represented: first, ahistorical and textual analysis of his philosophy has dominated, while his religious praxis has been ignored; and second, the Vedanticisation process, which has its origins in Orientalism, has not only figured in Ramana's construction as an Advaitin, but it also shaped later editions of his written works.

This section therefore aims to recognise the presence of additional aspects of Orientalist discourse in constructions of Ramana, and to highlight texthistorical problems in Ramana's written works. These points prepare the ground for the following section, in which I emphasise Ramana's religious praxis as a criterion better suited to frame his religious identity, i.e. as a Tamil Śaiva bhakta and not an Advaitin.

Gregory Schopen has demonstrated the extent to which Protestant values have influenced scholarly studies of Indian Buddhism, particularly the assumption that 'true' Indian Buddhism lay in the Pali canon. Schopen argues that "what originated as a sixteenth-century Protestant polemical conception of where 'true' religion is located has been so thoroughly absorbed into the Western intellectual tradition that...it is taken too often entirely as a given." ${ }^{69}$ This bias toward texts as the locus of religion is also relevant to the ways in which early

\footnotetext{
${ }^{68}$ Narasimha Swami, Self Realization, 70-71.

${ }^{69}$ Gregory Schopen, "Archaeology and Protestant Presuppositions in the study of Indian Buddhism," History of Religions 31 (1991): 14.
} 
Orientalists interpreted Hinduism. ${ }^{70}$ Subsequently, this trend in Orientalist discourse influenced nineteenth century Hindu reformers, who emphasised the authoritative role of sacred texts, typically the Vedas and the Upanișads. ${ }^{71}$ Moreover, representations of Ramana were tied up in these forces, and then later assumed as accurate in recent scholarly literature, which too, maintained a textual bias.

The combination of two Orientalist assumptions - that Hinduism was inherently mystical, and that religion is located in scripture - contributed to a process of Vedanticisation, in which Advaita Vedānta emerged as the most prestigious form and central doctrine of Hinduism. ${ }^{72}$ In their bid to understand true Hinduism, early Orientalists such as William Jones, H. T. Colebrooke and Max Muller looked to Vedic literature, and in particular the speculative Upanișads, i.e. the Vedānta, to locate its doctrinal core. ${ }^{73}$ Key Hindu reformers such as Roy and Vivekananda then followed Orientalists in identifying Advaita Vedānta as the doctrinal core of Hinduism, which in turn aided the construction of Hinduism as a single, unified religion. ${ }^{74}$

This is precisely the conception of Hinduism that Hindu intellectuals such as Radhakrishnan and T. M. P. Mahadevan wanted Ramana's alleged spiritual status to vindicate, hoping that it might function as a source of national pride to buttress nationalism (see section 2.2.3). However, this single, homogenous Hinduism existed solely in representation and not "on the ground," as Shulman, Frykenberg and Stietencron have argued. ${ }^{75}$ Likewise, Ramana's categorisation as an Advaitin is largely representational and the product of an elitist construct. If one wishes to categorise Ramana as an Advaitin, one must acknowledge that the Advaita in question is embedded in a construction of Hinduism conditioned by colonial India, thus rendering any ahistorical analysis problematic.

\footnotetext{
${ }^{70}$ Bandyopadhyay, From Plassey to Partition, 156.

${ }^{71}$ S. Cromwell Crawford, Ram Mohan Roy: Social Political and Religious Reform in $19^{\text {th }}$ Century India (New York: Paragon House Publishers, 1987), 39; D. Dennis Hudson, "Arumuga Navalar and the Hindu Renaissance Among the Tamils," in Religious Controversy in British India: Dialogues in South Asian Languages, ed. Kenneth W. Jones (Albany: State University of New York Press, 1992), 37; Flood, An Introduction to Hinduism, 251-55.

${ }^{72}$ King, Orientalism and Religion, 96, 101, 129.

${ }^{73}$ Ibid., 128.

${ }^{74}$ Ibid., 128-132.

${ }^{75}$ Gunther D. Sontheimer and Hermann Kulke ed., Hinduism Reconsidered (New Delhi: Ramesh Jain, 1991), 7, 21, 29.
} 
In addition, Ramana's written works present various text-historical problems. These problems lead us to doubt whether his written works are really a reliable, definitive source of his religiosity. The two main problems are contradictory statements on key doctrinal points, and major variations between the original edition of Who Am I? (Nān Yâar?) and later editions, which were clearly Vedanticised. As the Orientalist reliance on sacred texts as the locus of religion led to an artificial representation of Hinduism, so too has a heavy reliance on Ramana's written works, together with ahistorical analysis and a selective reading, led to the inaccurate categorisation of Ramana as an Advaitin.

Antithetical positions on the nature of the universe provide a striking example of the doctrinal tensions in Ramana's written works. In Śrī Ramaṇa Gìtā, the first comprehensive work on Ramana's teachings, Ramana responded to a devotee that he "does not consider the universe unreal." 76 Yet in Who Am I? arguably the most popular and well-known of Ramana's works - Ramana asserted that "there is no doubt whatsoever that the universe is the merest illusion."77 Ramana's precise position on a metaphysical principle fundamental to all schools of Hindu thought is therefore unclear. There are at least two ways of accounting for these contradictory statements. First, Ramana may have varied his style of response to suit the intellectual and spiritual capacity of the inquirer. ${ }^{78}$ Second, and far more probable, translators such as T. M. P. Mahadevan appear to have Vedanticised Ramana's works from the 1930s onwards. Here, for example, the position that "the universe is the merest illusion", which corresponds to Advaita, is taken from a text published after 1930 .

In addition to its Vedanticisation (which I will demonstrate immediately below), the origins and history of Who Am I? entail significant ambiguities, the extent to which should cause us to doubt it as a reliable source of Ramana's religiosity. Like all of Ramana's works, a devotee was the catalyst of Who Am I?, as opposed to Ramana composing the text independently and of his own volition. ${ }^{79}$ In 1902, Sivaprakasam Pillai, a philosophy graduate, put a series of

\footnotetext{
${ }^{76}$ Ganapati Muni, Śrī Ramaṇa Gītā, 9.

${ }^{77}$ Osborne ed., The Collected Works of Sri Ramana Maharshi, 10.

${ }^{78}$ Osborne, Ramana Maharshi and the Path of Self-Knowledge, 91.

79 According Suri Nagamma, Ramana admitted that he "did not write anything of his own accord." See Arunachala's Ramana, vol. VII, 194. Ramana also stated: "Somehow it never occurs to me to write any book or compose poems. All the songs I have made were made at the request of
} 
questions to Ramana, who answered them mainly through gestures, or by writing the answer on the floor or on a slate. Only one response was written down on a slate and then immediately copied onto paper by Sivaprakasam Pillai; the rest were merely memorised and written down subsequently. ${ }^{80}$ The outcome of this correspondence was first published in 1923 by Sivaprakasam Pillai himself, in the form of fourteen questions, and in Tamil. ${ }^{81}$ An English translation then appeared in Narasimha's original 1931 edition of Self Realization. ${ }^{82}$

Who Am I? was published in several different forms after 1923. One edition has thirty questions, another (such as the current edition) has twenty-eight, while another version appears as a twenty paragraph essay, which was based on Sivaprakasam Pillai's original Tamil edition and possibly written in Tamil by Ramana. ${ }^{83}$ An English translation (referred to as a "free translation") of the essay first appeared in February, 1930, in a monthly journal entitled "Peace". ${ }^{84}$ Unfortunately, the translator is never clearly specified in any of the English versions. The two different English translations that I mainly refer to below, however, were most likely the work of B. V. Narasimha Swami, in the case of the original 1923 version, and T. M. P. Mahadevan, in the case of the current edition, which Mahadevan states was based on the essay version. ${ }^{85}$

The significant variations between the original 1923 version of Who Am I? and later editions, which appeared from 1930 onwards, best demonstrate the Vedanticisation of Ramana's written works. Here we see evidence of a shift, in which the original version corresponds to Śaiva Siddhānta terminology and concepts, while later editions employ Vedāntic terms, such as 'the Self' and 'Brahman'. Importantly, this shift coincides with Ramana's emergence as a panIndian and internationally acclaimed figure.

The first dramatic difference appears in question four of the original 1923 version, which corresponds to question three in the current edition, and deals with the nature of consciousness. The current version simply states that "the

someone or other in connection with some particular event." See Mudaliar, Day by Day with Bhagavan, 225.

${ }^{80}$ Narasimha Swami, Self Realization, 74.

${ }^{81}$ Arunachala's Ramana, vol. I, 154.

${ }^{82}$ Narasimha Swami, Self Realization, 77-81.

${ }^{83}$ Arunachala's Ramana, vol. I, 154, 158.

${ }^{84}$ Ibid., 614-621.

${ }^{85}$ Ramana Maharshi, Who Am I?, 3. 
nature of awareness is Existence-Consciousness-Bliss." ${ }^{" 86}$ The original edition is far more expansive and goes on to discuss the three essential ontological categories of Śaiva Siddhānta; paśu, pāśa, pati (the soul, the bond to the world and god), concluding that Sivaswarupa (the true nature or form of Śiva) is "Real". 87

A further example of the rhetorical shift from Śaivism to Vedānta may be seen in question five and six of the original, in which Sivaprakasam Pillai inquires into how one might "realise Śivaswarupa." that the corresponding questions have been Vedanticised to "When will the realization of the Self be gained?" and "Will there not be realization of the Self even while the world is there?" 89

Two additional examples further demonstrate this rhetorical shift. First, the current edition makes reference to 'Brahman', the absolute metaphysical principle of Vedānta, which appears in the answers to questions twenty four and twenty seven. ${ }^{90}$ Strikingly, 'Brahman' does not appear at all in the original, in which the Śaiva term Śivaswarupa is clearly used to signify 'the Supreme'. 91

Perhaps the most dramatic difference between the two versions appears in question sixteen of the current edition, which asks: "What is the nature of the Self?" The answer given corresponds to Advaita metaphysics: "What exists in truth is the Self alone...all is Śiva, the Self." Although 'Śiva' still appears, this statement exemplifies the kind of Vedanticised assertion that the likes of Forsthoefel have latched onto to support Ramana's alleged "radical nondualism." ${ }^{92}$ However, this statement does not appear in the original edition, which concludes after question fourteen. This Vedanticised language is a later addition, which suggests that there has been a deliberate attempt by either Ramana himself, or translators such as Mahadevan, or even both of them by degrees, to Vedanticise Ramana's works to increase their appeal and their orthodoxy in a pan-Hindu way.

In sum, this section has identified several problems in treating Ramana's written works as the location of his religiosity, and in doing so, further

\footnotetext{
${ }^{86}$ Ibid., 6.

87 “Cited in" Narasimha Swami, Self Realization, 78.

88 Ibid.

${ }^{89}$ Ramana Maharshi, Who Am I?, 6.

${ }^{90}$ Ibid., 14-16.

${ }^{91}$ See Narasimha Swami, Self Realization, 77-81.

${ }^{92}$ Forsthoefel, Knowing Beyond Knowledge, 133.
} 
contends that it is inaccurate to categorise Ramana as an Advaitin. It has also highlighted the failure of scholarship to recognise the presence of additional legacies of Orientalism in the construction of Ramana, such as a heavy reliance by scholars on textual sources in characterising his religiosity, and the Vedanticisation of his works over time. If we are to class Ramana as an Advaitin, we must acknowledgement that the Advaita here labels a form of Hinduism that was constructed by historical processes, thus rendering any ahistorical analysis problematic.

These issues explain, to a considerable extent, why recent scholarship has misinterpreted and misrepresented Ramana. As I will now show, another part of the problem lies in the failure to pay due attention to Ramana's religious praxis, which I claim offers a more accurate way of framing his religiosity.

\subsection{The Tamil Śaiva bhakta}

Ramana's Tamil brahman family followed the Purāṇic-based Smārta religion. ${ }^{93}$ According to Indira Peterson, "Tamil Smārtas identify themselves as Śaivas, and worship in Śiva temples." 94 Both points hold true with Ramana: (1) Ramana habitually wore the Śaiva markers of vibhüti (sacred ash) and kumkum on his forehead. ${ }^{95}$ (2) Ramana worshipped at Śaiva temples throughout his life, such as the Meenakshi temple in Madurai, the Arunachaleswara temple in Tiruvannamalai, and the Mathrubhuteswara temple in Sri Ramanasramam. Ramana oversaw the construction of the latter temple, participated in regular $p \bar{u} j \bar{a}$ (worship ritual) and requested the continuance of regular $p \bar{u} j \bar{a}$ after his death. ${ }^{96}$

This section argues that Ramana is more accurately identified with the Tamil Śaiva bhakti tradition, rather than with Advaita, as scholars typically claim. To support this claim I focus on what Ramana did in terms of religious praxis, emphasising his steadfast devotional relationship to his ișta-devatā (chosen deity), Arunachala, a distinctly Tamil Śaiva deity. Recent scholarship on Ramana has tended to ignore or temper this devotional relationship, as seen in the case of

\footnotetext{
${ }^{93}$ Bhikshu, Sri Ramana Leela, 4. Smārtism requires the domestic worship of five shrines and their deities, a practice referred to as pañcāyatana pūjōa. The deities worshipped are Śiva, Viṣnu, Gaṇeśa, Surya and Devī.

${ }^{94}$ Indira Viswanathan Peterson, Poems to Śiva: the Hymns of the Tamil Saints (Delhi: Motilal Banarsidass, 1991), 55.

${ }_{95}$ Narain, ed., Face to Face with Sri Ramana Maharshi, 66; 145.

${ }^{96}$ Chadwick, A Sadhu's Reminiscences, 55-57.
} 
Forsthoefel: “The closest thing to a 'personal deity' for Ramana is Arunachala hill itself, but this clearly is a symbol for non-dual consciousness and represents the inner 'I' or 'heart.", 97 I propose an alternative interpretation of Ramana's relationship with Arunachala, i.e. a devotional and thus dualistic one, which challenges Forsthoefel's claim that Ramana expounded a "radical non-dualism."

I base my argument on the following points: (1) The Periya Purānam, a canonical Tamil Śaiva text extolling the bhakti of sixty three saints, profoundly influenced Ramana in the months prior to his alleged 'awakening', and the ways in which he interpreted his transformative experience. (2) Ramana conceived of and worshipped Arunachala as something uniquely special and distinct from the rest of the phenomenal world, and moreover, as a manifestation of Śiva. (3) Ramana revered the major saints of Tamil Śaivism, along with their canonical texts, such as the Tēvāram, Tiruvācakam and Tirumantiram, which also shaped Ramana's view of orthopraxy. In framing Ramana as a Tamil Śaiva, I aim to consider and appreciate the complexity and diversity of Hindu religions, and further challenge representations of a single, homogenous Hinduism born out of the colonial encounter.

\subsubsection{The Periya Purānam and Ramana's 'God-mad' state in Śaiva temples}

In a bid to emphasise the details of Ramana's transformative experience at sixteen, scholarship has paid little attention, if any, to Ramana's behavioural tendencies immediately following his alleged 'awakening'. Further, it has failed to adequately consider the influence of the Periya Purānam, a Tamil Śaiva canonical text that had achieved popularity and importance during the latter half of the nineteenth century, largely on account of the reformist strategies of Arumuka Navalar (1822-1879). ${ }^{98}$

Ramana admitted that the Periya Purānam, a text he only began reading several months prior to his alleged 'awakening', made a "great impression" on him. ${ }^{99}$ Narasimha described Ramana's attitude to this Tamil Śaiva text as one of

\footnotetext{
97 Ibid.

${ }^{98}$ Navalar published a prose rendition of the Periya Purānam in 1851 to make the text more accessible. This strategy was one of many aimed at reforming Tamil Śaivism. See D. Dennis Hudson, "Arumuga Navalar and the Hindu Renaissance Among the Tamils," in Religious Controversy in British India: Dialogues in South Asian Languages, ed. Kenneth W. Jones (Albany: State University of New York Press, 1992), 27-44.

${ }^{99}$ Arunachala's Ramana, vol. I, 51.
} 
"admiration, awe and reverence." 100 The main theme of the Periya Purānam is bhakti (devotion), which is expressed through the Nāyanāās' (sixty three saints) intense relationship with Śiva. Ramana stated that this was precisely the impression that it made on him. ${ }^{101}$ The extent to which the Periya Purānam influenced Ramana may be seen not only in his encounter with it just prior to his transformative experience, but also in the ways that he used the text to interpret this experience.

In the period immediately following his alleged 'awakening', Ramana frequently visited the Meenakshi temple. During these visits the saints of the Periya Purānam and their bhakti dominated his thoughts. Ramana stated: "I used to go daily to the temple and pray that I should become devoted like one of the sixty-three saints [Nāyañārs] of Periya Purānam." ${ }^{102}$ In another example, Ramana admitted: "I used to go and weep before those images and before Națarāja (a manifestation of Śiva) that God should give me the same grace He gave to those saints." ${ }^{103}$ He further declared that he would pray for Siva's grace that he might emulate the devotion of the Nāyanārs. ${ }^{104}$ It is clear that Ramana was using the bhakti found in the Periya Purānam as a framework with which to interpret his transformative experience. Further, these statements reveal important details of Ramana's religious praxis, i.e. he went to a Śaiva temple and prayed to Śiva.

Devaraja Mudaliar commented on the ways in which bhakti and longing for Śiva dominated Ramana's thoughts following his alleged 'awakening'. Mudaliar reported that Ramana once narrated a story from the Bhakti Vijayam, in which he compared the "God-mad" state of Tulsidas to his own state in Madurai as a sixteen year old. Ramana described his "God-mad" state as follows: "Going to school, books in hand, I would be eagerly desiring and expecting that God would suddenly appear before me in the sky; and so I would be looking up at the

\footnotetext{
${ }^{100}$ Narasimha Swami, Self Realization, 13.

101 Arunachala's Ramana, vol. I, 570.

102 Ibid., 570. The importance Ramana held for the Meenakshi temple lasted throughout his life. In September 1947, a plate containing vibhüti (sacred ash) from the Meenakshi temple arrived at Ramana's ashram. Suri Nagamma writes that Ramana held the plate "reverentially", then said, 'See, this is Meenakshi's gift,' as he smeared the sacred ash and kumkum on his forehead. Suri notes that Ramana became choked with emotion during the event. See Arunachala's Ramana, vol. VII, 143.

103 Ibid., 58.

104 Ibid., 57.
} 
sky." 105 Mudaliar remarked that he had never before heard that Ramana "was so God-mad" in Madurai. ${ }^{106}$ That Ramana so "eagerly desired" to see Śiva, again demonstrates the influential role of the Periya Purānam and its theme of bhakti. Additionally, Ramana's devotional longing for a personal god after his alleged 'awakening' further contests the reading of any non-dualistic realisation into his transformative experience.

Approximately two months after his transformative experience, Ramana left his family home in Madurai for Arunachala, leaving only a brief note beginning with: "I have set out in quest of my Father in accordance with his command." ${ }^{107}$ Narasimha claimed that the note's "chief feature" is Ramana's "powerful faith in Iswara, 'Arunachala', who was calling him." ${ }^{108}$ Ramana's first act upon arrival supports this point: he took darśan (to see) of the temple deity, Arunachaleswara. Bhikshu recorded that upon seeing the lingam, Ramana exclaimed: "Father, I have come according to your bidding, I offer myself to you." 109 According to Narasimha, Ramana addressed the deity as follows: "O God, obedient to thy call, here I have come, deserting all." ${ }^{110}$ Narasimha went on to describe this event as "the supreme moment" of Ramana's life. ${ }^{111}$ These points stress the centrality of the Saiva temple in Ramana's life, particularly in the months immediately after his alleged 'awakening'. Ramana's devotion to Śiva, and even Siva in the form of Arunachala, is also clear. Ramana's religious praxis, therefore, belongs definitively to Tamil Śaivism.

\subsection{2. "This Hill is Śiva Himself"}

From the time that he arrived at Arunachala in 1896 until his death in 1950, Ramana never moved more than two miles from the base of the hill. ${ }^{112}$ In fact, he spent most of that time either on the hill itself or at its foot. This feature of Ramana's life should not be seen as incidental, but rather as the definitive aspect of his religiosity, and further, his actions should be interpreted within a framework

\footnotetext{
${ }^{105}$ Mudaliar, Day by Day with Bhagavan, 2-3.

${ }^{106}$ Ibid., 3.

${ }^{107}$ Osborne, Ramana Maharshi and the Path of Self-Knowledge, 25-26.

${ }^{108}$ Narasimha Swami, Self Realization, 26.

${ }^{109}$ Bhikshu, Sri Ramana Leela, 39.

${ }^{110}$ Narasimha Swami, Self Realization, 36.

111 Ibid., 37.

112 Godman, Be As You Are, 2.
} 
of praxis, i.e. as an expression of Ramana's steadfast devotion to Siva. Importantly, Ramana often referred to Arunachala as something uniquely special and distinct from the rest of the phenomenal world. These references stand in tension against claims to an exclusive Advaitin worldview, but are compatible with a Śaiva bhakti framework.

The following two examples illustrate Ramana conceiving of Arunachala as Śiva and “God Himself”. First, in conversation with Prof. G. V. Subbaramayya, Ramana asserted: "Other sacred hills are described as the abodes of some deity. But Arunachala is God Himself in the shape of a Hill." ${ }^{113}$ Second, in response to Paul Brunton's question about Arunachala, Ramana declared: "Kailash is the abode of Śiva, whereas this Hill is Śiva Himself."114 These proclamations - to an Indian intellectual and to a Western author - clearly contradict Forsthoefel's claim that Arunachala is merely "a symbol for non-dual consciousness" to Ramana.

Ramana's devotion to his iṣta-devata is further supported by a distinct form of praxis, in which the devotee circumambulates the base of the hill. Giripradakșina, or circumambulating the fourteen kilometre base of Arunachala, is one of the distinctive ways that Tamil Saivas worship Siva. This ritual is particularly popular on full moon nights each month, and during the annual Deepam festival held in November/December. Narasimha emphasised Ramana's regular practice of undertaking giripradakșina to worship Arunachala from his arrival in 1896 until 1927, when he abandoned the practice in favour of his selfimposed duty of giving darśan. ${ }^{115}$ Not only did Ramana engage in this form of ritual worship, but he advised his own devotees to follow this practice on account of the "special sanctity" of walking around "God Himself." "116 Ramana's thirty year practice of giripradakșina clearly demonstrates his devotional relationship to Arunachala, and is further evidence that Ramana ought to be identified with the Tamil Śaiva bhakti tradition.

The cessation of this form of worship in 1927, however, does not signify the end of Ramana's bhakti. During the 1940s, Ramana habitually read from the Arunachala Purānam, a collection of myths about the hill as Śiva. Mudaliar noted

\footnotetext{
${ }^{113}$ Narain, ed., Face to Face with Sri Ramana Maharshi, 105.

${ }^{114}$ Venkataramiah, Talks with Sri Ramana Maharshi, 128.

${ }^{115}$ Narasimha Swami, Self Realization, 183.

${ }^{116}$ Narain, ed., Face to Face with Sri Ramana Maharshi, 105; Arunachala's Ramana, vol. V, 225.
} 
that on these occasions it was typical for Ramana to become choked with tears and emotion, such that he could not continue. ${ }^{117}$

The following example, also from the 1940s, illustrates the ongoing devotion Ramana felt for Arunachala. During the Deepam festival procession of the temple deity, Arunachaleswara, in November 1945, the ârati plate offered to the deity was brought to Ramana. Suri Nagamma recounted that Ramana took the vibhūti (sacred ash) and applied it to his forehead, saying 'Appakku Pillai Adakkam' (the son is beholden to the Father). She also remarked that his voice was "choked with emotion." 118 This evidence is revealing in a number of ways. First, it shows Ramana participating in conventional forms of Tamil Śaiva ritual, i.e. receiving and applying the sacred ash, a definitive symbol of Śaivism. Second, almost fifty years after he left Madurai with a parting note that declared that he "set out in quest of his Father," Ramana still conceived of Arunachala as his 'Father' and god. ${ }^{119}$ Last, that Ramana became "choked with emotion" illustrates the intense devotion to Arunachala that he still felt.

The centrality of Arunachala in Ramana's religiosity was certainly clear to south Indian observers, and this is likely because they had the necessary framework with which to understand it. M. S. Kamath, writing in 1936, allocated two pages to Ramana's teachings, in which he emphasised self-enquiry and the search for happiness (he makes no mention of Advaita). ${ }^{120}$ Contrastingly, Kamath dedicated seven pages to Ramana's devotional relationship with Arunachala, citing several verses from his Tamil devotional poems. ${ }^{121}$ Narasimha stressed that Ramana's spiritual state shifted between "passive characterless consciousness" and "deep devotion to a personal God." 122 Devaraja Mudaliar, however, perhaps best captured the difference between those with limited exposure to Ramana's bhakti and others who comprised his more intimate circle of devotees:

To those who have only a very superficial knowledge of him or his works, it might seem that he was a cold, relentlessly logical unemotional jūanni, far removed from the bhakta who melts into tears in contemplation of God's grace and love. But to those who

\footnotetext{
${ }^{117}$ Arunachala's Ramana, vol. V, 222.

118 Ibid., 193.

${ }^{119}$ Ibid., 26.

${ }^{120}$ Kamath, Sri Ramana Maharshi: a Biography with 111 Illustrations, 47-48.

121 Ibid., 39-46.

${ }^{122}$ Narasimha Swami, Self Realization, 38.
} 
had any real experience of Bhagavan and his ways, and works, it was clear that he was as much a bhakta as a jūanni. ${ }^{123}$

Mudaliar followed this passage with several examples of Ramana encouraging acts of bhakti. ${ }^{124}$ Nonetheless, Mudaliar rightly aimed to correct "superficial" representations of Ramana which failed to emphasise the centrality of bhakti in his religiosity.

\subsubsection{The Tamil Śaiva saints and sacred texts}

The ways in which the Tamil Śaiva bhakti tradition features in Ramana's religiosity may be further seen in his reverence for the Tamil Śaiva saints and their compositions. As seen above, the bhakti contained in the Periya Purānam made an immense impression on Ramana as a sixteen year old. Ramana's "admiration and reverence" for this canonical text of Tamil Śaivism, however, was not confined to that initial transformative period, but endured to the end of his life. Suri Nagamma highlighted Ramana's "enthusiasm" for narrating stories from the Periya Purānam, ${ }^{125}$ and detailed numerous examples throughout 1947-48 alone. ${ }^{126}$ Of the sixty three saints extolled in the Periya Purānam, Ramana held particularly high reverence towards the four Nalvars - Campantar, Cuntarar, Appar and Mānikkavācakar - along with their compositions, the Tēvāram and Tiruvācakam. ${ }^{127}$ Further, these works held a central place in the ritual culture that grew up around Ramana.

Two south Indian devotees of Ramana, Suri Nagamma and Devaraja Mudaliar, again give compelling evidence of Ramana's reverence for the Tamil Śaiva saints and their works. On numerous occasions both Mudaliar and Suri Nagamma depicted Ramana narrating stories about the saints or referring to their songs only to stop because he had become "choked with emotion". One example may be seen in the case of Cuntarar, in which Mudaliar described Ramana's emotional response as follows: "While reading various passages extolling the saint, Bhagavan could hardly proceed, being so choked with emotion. At least a

\footnotetext{
123 A. Devaraja Mudaliar, My Recollections of Bhagavan Sri Ramana (Tiruvannamalai: Sri Ramanasramam, 2009), 46.

${ }^{124}$ Ibid., 51.

${ }^{125}$ Arunachala's Ramana, vol. VI, 55.

${ }^{126}$ Ibid., vol. VII, 40-44; 46-47; 145; 194-95; 221.

${ }^{127}$ Mudaliar, My Recollections of Bhagavan Sri Ramana, 55.
} 
dozen times he was so choked and he had to control himself and then proceed." $" 128$ In another example, Ramana narrated the story of Mānikkavācakar from the Halasya Mahatmyam. Suri stated: “As he narrated the story, Bhagavan's voice got choked. Unable to speak anymore he remained in ecstatic silence." ${ }^{129}$ In addition, Mudaliar noted that Ramana frequently quoted from Māṇikkavācakar's canonical text, the Tiruvācakam, and advised his devotees to read it. ${ }^{130}$

Not only did narrating stories about the saints evoke emotional states in Ramana, but hearing the Têvāram and Tiruvācakam produced the same reaction. On festival days during the Virupaksha cave period (1899-1916), bhajan (devotional singing) parties visited Ramana and sang the Têvāram and Tiruvācakam. On these occasions, devotees invariably witnessed tears rolling down Ramana's cheeks. ${ }^{131}$ There are other anecdotal examples that demonstrate Ramana's reverence for the Tēvāram and Tiruvācakam. ${ }^{132}$

Perhaps the most significant evidence lies in the way these devotional poems informed the ashram culture that surrounded Ramana. The Têvāram and Tiruvācakam comprised the Tamil parayanam (devotional singing) that occurred twice daily at Sri Ramanasramam prior to 1935 and once in the evening from that time onwards. ${ }^{133}$ Mudaliar also noted that Ramana would insist on the recitation of the Têvāram. ${ }^{134}$ The Têvāram and Tiruvācakam also featured in formal, ceremonial occasions in Ramana's life, such as the death of his mother. These distinctly Tamil Śaiva texts were recited for the duration of the night after Ramana's mother passed away in $1922 .{ }^{135}$ Kunju Swami stated that Ramana ordered for the Tiruvāchakam to be recited in its entirety, and even recited sections himself. ${ }^{136}$ The Tềāram and Tiruvācakam therefore played a central role in the ashram culture that surrounded Ramana, and in Ramana's own religious praxis. Ramana's use of and reverence for these canonical texts of Tamil Śaivism further support the claim that he ought to be identified with Tamil Śaivism.

\footnotetext{
128 Arunachala's Ramana, vol. V, 297.

${ }^{129}$ Ibid., vol. VII, 147-52.

${ }^{130}$ Mudaliar, My Recollections of Bhagavan Sri Ramana, 53.

${ }^{131}$ Ibid., vol. II, 191.

${ }^{132}$ For example, see Arunachala's Ramana, vol. V, 21-22, 222; Mudaliar, My Recollections of Bhagavan Sri Ramana, 53.

${ }^{133}$ Godman, Living by the words of Bhagavan, 114. Veda parayanam began in 1935.

${ }^{134}$ Mudaliar, My Recollections of Bhagavan Sri Ramana, 56.

${ }^{135}$ Narasimha Swami, Self Realization, 142.

${ }^{136}$ Kunju Swami, Living with the Master (Tiruvannamalai: Sri Ramanasramam, 2008), 64.
} 
The passing of Ramana's mother provides additional evidence of the ways in which the Tamil Śaiva canon informed Ramana's religiosity. Kunju Swami noted that the burial and samädhi (shrine) preparations for Ramana's mother were carried out according to Tirumūlar's canonical work, Tirumantiram. ${ }^{137}$ Ramana also insisted on consulting the Tirumantiram when Seshadri Swamigal, a local saint of Tiruvannamalai, passed away in $1929 .{ }^{138}$ On these formal, ceremonial occasions, Ramana's reliance on the sacred texts of Tamil Śaivism clearly demonstrates his own identification with the tradition, along with the ways that this tradition shaped his view of orthopraxy.

In sum, in this section I have argued that it is more accurate to place Ramana within the Tamil Śaiva bhakti tradition, than to categorise him as an Advaitin. To support this claim, I demonstrated the pivotal role of the Periya Purānam, which profoundly influenced Ramana in the months prior to his alleged 'awakening', and in the ways that he interpreted his transformative experience most strikingly represented by his desire to emulate the bhakti of the Tamil Śaiva saints. This wish to live a life devoted to Siva manifested itself in his devotional relationship to Arunachala, which Ramana conceived of and worshipped as his ișta-devatā. We also saw evidence that Ramana revered the Nalvars; Campantar, Cuntarar, Appar and Māṇikkavācakar, which illustrated his own identification with Tamil Śaivism. Finally, I showed that the canonical texts of Tamil Śaivism, in particular, the Têvāram, Tiruvācakam, and Tirumantiram, shaped Ramana's view of orthopraxy.

This characterisation of Ramana as a Tamil Śaiva is strengthened further if we consider that the vast majority of Ramana's devotees held him to be an incarnation of Campantar or the Tamil Śaiva deity, Murukan. ${ }^{139}$ This ethnic sectarian conception of Ramana contrasts greatly with his more famous and panHindu representations, i.e. as the Maharshi and Advaitin, owing to figures such as Ganapati Muni and S. Radhakrishnan, both of whom harboured nationalistic agendas. In identifying Ramana as a Tamil Śaiva, I aim to emphasise the importance of orthopraxy in Hindu religions, and also consider and appreciate the complexity and diversity within Hinduism.

\footnotetext{
${ }^{137}$ Ibid., 65.

${ }^{138}$ Narasimha Swami, Self Realization, 287.

${ }^{139}$ Kamath, My Motherland, 5; Bhikshu, Sri Ramana Leela, 32-33, 131, 312-13; Arunachala's Ramana, vol. II, 89-90, 93;
} 


\subsection{Conclusion}

While acknowledging that several of Ramana's ontological assertions refer to non-dualism, I have demonstrated that his religiosity is not exclusively and definitively compatible with Advaita Vedānta. This chapter has therefore argued that Ramana's categorisation as an Advaitin is more dependent upon the fruits of Orientalism, Hindu reform and certain political needs of the colonial period, than upon the nature or content of his alleged 'awakening' and subsequent teachings. As such, Ramana's status as an Advaitin ought to be viewed as an elitist construct, and not considered as an accurate description of his religiosity. That many of Ramana's devotees believed him to be an incarnation of Campantar or the Tamil Śaiva deity, Murukan, both of which are ethnic-sectarian figures, further accentuates this point.

Additionally, the evidence presented in this chapter further supports the claim in Chapter Two that Hindu intellectuals constructed Ramana as an Advaitin to vindicate Hinduism and generate national pride. If one therefore wishes to define Ramana as an Advaitin, one must recognise that the Advaita he belongs to is a colonial construct, which in turn demonstrates that Ramana was a product of his time. This implies that any ahistorical analysis that uncritically follows the rhetoric of devotional literature will lead to a misinterpretation and misrepresentation. Unfortunately, this has hitherto been the trend in scholarship on Ramana.

Further, Ramana's ontological and soteriological inclusivism followed a trend set by Ramakrishna and Vivekananda, and thus echoed and contributed to ideologies aiming at the construction of a single, unified Hinduism. Contrary to claims that Ramana's teachings are equally "appropriate to twentieth century Hinduism" as they are "to first century Hinduism," this point has demonstrated yet again that Ramana participated in colonial dynamics in important ways. ${ }^{140}$ Importantly, Ramana's participation in the liberation struggle therefore goes beyond a symbolic role as a Maharshi or Advaitin, extending to his contribution to Hindu reform during the colonial period, which was a dynamic process involving Orientalists and Hindu intellectuals that radically transformed representations of Hindu religion.

\footnotetext{
${ }^{140}$ See above.
} 
Finally, after showing that the Advaitin label is inaccurate, I presented evidence that emphasised Ramana's religious praxis, rather than locating his religiosity in written works. The evidence here demonstrated that Ramana ought to be primarily identified with the Tamil Śaiva bhakti tradition. There were two key themes at stake here. First, I sought to avoid the trend in scholarship on Ramana that followed Orientalism in its assumptions, textual bias and tendency to ignore orthopraxy, and in creating misleading representations. Second, following Shulman, Frykenberg and Stietencron, I sought to look beyond representations of Hinduism borne out of the colonial encounter that portrayed it as a single, unified world religion. Instead I aimed to consider and appreciate the diversity and complexity of Hindu religions, in this instance exemplified by the ethnic-sectarian Tamil Śaiva bhakti tradition. 


\section{Conclusion}

In adopting the supposed timeless and purely spiritual Ramana Maharshi as a case study, this thesis has allowed us to think about the effect of colonial dynamics on Hindu religiosity in a number of ways. We have been pressed to reflect on the interaction between nationalist discourse and Hindu spirituality, and in particular, the role that the seemingly purely spiritual played in political agendas. Moreover, the previous chapters have presented new material that has lent insight into the ways that politically-motivated Hindus interpreted and represented their religious figures during the nationalist era. Ramana Maharshi has served as a striking example here because his image was largely the result of others, i.e. Ganapati Muni, B. V. Narasimha Swami and T. M. P Mahadevan, and not of his own selfpromotion or self-styling. In addition to his construction as a Maharshi and the living embodiment of Advaita, Ramana Maharshi's image as a timeless and purely spiritual figure captures this point of inquiry to a considerable extent. Ironically, this ahistorical image firmly locks him into his historical situation, and further, it speaks of the influence of Orientalist discourse on the Hindu religious landscape.

This study consistently identified Orientalism at the root of the various historical processes that shaped Ramana Maharshi. This point stresses the impact of colonial dynamics on Hinduism, as these very historical processes included the participation of key Hindu figures who embraced Orientalist assumptions and used them in their reform and anti-colonial strategies. For example, the Aryan theory of the early Orientalists evoked an affirmative response from nineteenth century Hindu reformers such as Roy, Dayananda Saraswati and Vivekananda, who reinterpreted the Vedic period as a Golden Age to which Indian society must return. The Golden Age ideology became a mainstay of nationalist discourse, and as I have argued, it deeply influenced Ganapati Muni, who in 1907 promoted Ramana as a Great Vedic Rishi for political purposes. This event inaugurated a process by which a localised, unorthodox and ethnic-sectarian ascetic, i.e. Brahmana Swami, came to embody an orthodox and supreme religious authority in a pan-Hindu way, i.e. Ramana Maharshi. In this context, Ramana reflects two key trends concerning the ways that Hindu figures idealised Hinduism during the colonial period. First, we see the tendency to emphasise pan-Indian and 
monolithic representations, rather than localised and sectarian conceptions of religiosity. Second, we see popular bhakti movements (i.e. the worship of Śiva, Viṣnu and Devī) overlooked in favour of promoting the more 'pure' Vedic and Upanișadic ideals. Both of these trends were mutually influenced and galvanised by the need for Indians to imagine a national identity in order to achieve political liberation.

The manner in which hagiographers of Ramana represented Ganapati Muni - as a Sanskrit poet and spiritual adept, and not the radical freedom fighter alternative sources revealed him to be - alerted us to a deliberate effort to deny the political sphere in the Ramana narrative. I stressed this point by presenting evidence that Ramana was indeed politically interested and inclined, despite Arvind Sharma's claim to the contrary, and despite the fact that hagiographers portrayed Ramana as purely spiritual. Here we saw the influence of the Orientalist dichotomy of East and West, which had shaped Vivekananda's reform strategies, including his ardent promotion of the rishi ideal. Hagiographers of Ramana such as the nationalist B. V. Narasimha Swami, who had been influenced by Vivekananda, thus assumed this dichotomy and constructed a Ramana narrative that excluded anything political or worldly in order to legitimise Ramana's status as a rishi. This colonial conception of the rishi entails a dramatic shift from traditional understandings of the rishis, in which they performed worldly, social and political duties. The influence of Orientalism on Hindu religiosity is therefore again evident.

Paul Brunton further exaggerated Ramana's purely spiritual persona by depicting him with an additional set of Orientalist assumptions. Brunton's act of projecting romantic Orientalist stereotypes onto "the Maharishee" crystallised Ramana's popular image - in both Indian and Western imaginations - as otherworldly, timeless, ancient and mystical. Brunton's legacy should not be confined to his romantic portrayal, however, because the success of his book also played a significant role in Ramana's transition from a localised ascetic to a panIndian religious authority. Ramana's fame attracted international recognition, but importantly, it drew the attention of Hindu elites concerned with the nationalist project, who exploited the appeal of the mythic Maharshi symbol, as Brunton did, yet with anti-British/imperial intentions. This point underlined the unique Indian situation in which Hindu spirituality - or the purely spiritual - contributed to 
nationalist discourse and agendas in significant ways. Thus the timeless Ramana, as I have argued, was not only significantly shaped by his historical situation, but he was also important to the colonial period on account of the symbolic role he played.

Moreover, Ramana's symbolic political role reveals the intersection of anti-imperialism and an image grounded in Orientalist stereotypes. This point contrasts Said's thesis that Western imperialism perpetuated Orientalism to dominate Asia. This Indian and anti-imperial view of Orientalism demonstrates the unilateral dimension of Said's argument, and urges us to consider the extent to which Said's work can be problematised because of the failure to adequately include India's colonial encounter in its analysis. In addition, it perhaps forces us to realise the significance of another feature of colonial dynamics, namely, key Hindu figures who received a British education and engaged with Western audiences. If Said had considered the work of Roy, Vivekananda, Aurobindo and Gandhi, he would have needed to adjust his position on Orientalism and not present it solely as an imperial instrument, but rather in a way that acknowledged the tension between imperialism and anti-imperialism.

Ramana's categorisation as an Advaitin powerfully captures the ways in which Hindu intellectuals interpreted and represented their religious figures during the colonial period, and again highlights the impact of Orientalism on Hindu reform and nationalist discourse. As I have argued, Ramana's status as an Advaitin should be seen as an elitist construct that owed much to the Vedanticisation process and the interaction between nationalist discourse and Hindu spirituality - a claim that sharply contrasts the popular and scholarly assumption that it accurately reflected his transformative experience at sixteen. The Vedanticisation process relied on the initial efforts and assumptions of early Orientalists as well as the proceeding strategies of key Hindu reformers. This process produced a powerful religious symbol - Advaita Vedānta - which represented the highest doctrine of a single, homogenous religion. Apart from simultaneously functioning in a religious and political way, Advaita Vedānta followed the Maharshi construct in that it reflects the trend of Hindu reformers to conceive of Hinduism in terms of Vedic and Upanișadic ideals rather than in popular forms of bhakti such as Tamil Śaivism. It also speaks of the tendency of Hindu figures of the colonial period to emphasise doctrine, philosophy and a 
universal religious experience instead of ritual, worship and anything related to a 'superstitious' polytheistic worldview.

These concluding threads raise the following question: why was the purely spiritual, otherworldly and timeless Maharshi such a powerful symbol during the nationalist period? There are several contributing factors at play here, the most important of which seem to hinge upon or derive from the dichotomy of East and West. The British used this dichotomy to define themselves not only as separate and distinct from their Indian subjects, but superior to them, and importantly, in a way that allowed them to justify their colonial rule. In claiming their sovereignty over the material/political sphere, the British 'safely' relegated India to the spiritual sphere. I therefore suggest that the purely spiritual Maharshi was a particularly powerful figure, in part, because it followed a defining characteristic of India that the British had originally determined, thus allowing Hindu-Indians a sense of immunity from British criticism. To contest the truthfulness of this trait would likely make the whole schema that defined Britain as materially and politically superior to India suddenly questionable. Further, this point would have aided and perpetuated the process by which Vivekananda et al. reinvented the defining spiritual 'essence' of India as a source of pride and the focus of national identity.

In addition, Partha Chatterjee provides an insightful framework with which to approach this question. Chatterjee argues that nationalist discourse transformed "the material/spiritual distinction" and created a more "condensed" and "powerful dichotomy: that between the outer and the inner." 'The inner', according to Chatterjee, contained the spiritual, and importantly, "true identity."2 At stake here is India's national identity, which required a collective project that aimed at protecting, fortifying and preserving the distinctive quality of national culture, i.e. its spirituality. Whereas the British ruled the outer/public/material sphere, Indians still had sovereignty over the inner/private/spiritual sphere, and thus the agency to define and maintain their identity.

These currents - the spiritual, 'the inner', identity and the quest of selfhood - converge in the symbol of the purely spiritual Maharshi, who becomes a

\footnotetext{
${ }^{1}$ Chatterjee, Partha. "The Nationalist Resolution of the Women's Question," in Recasting Women: Essays in Indian Colonial History, ed. Kumkum Sangari and Sudesh Vaid (New Brunswick, New Jersey: Rutgers University Press, 1990), 238. ${ }^{2}$ Ibid.
} 
powerful authority figure and the ideal of this very domain. In the case of Ramana, the Great Rishi and Advaitin, Indians who came to see him were typically motivated by the quest for self-realisation. Ramana consistently advised aspirants to focus their attention on an inward quest based on the enquiry 'who am I?'. There are interesting parallels here between the quest for personal identity and the nationalist search for an Indian identity. Ramana's answer to 'who am I?' in fact responds to both questions, in that he proposes a radical internalism that is purely spiritual. As we have seen, Ramana's teachings have been promoted by Hindu intellectuals as Advaita Vedānta. While Vivekananda and other reformers promoted the universalism of Advaita Vedānta, the thing that was most important about Advaita concerned its Indian origins. Thus Hindus from all over India could look to the purely spiritual Maharshi as a symbol that inspired them to preserve their distinctive national culture and identity, which of course entailed forcing the British to 'quit India'.

This thesis has also identified problems concerning the study of Asian religions. As I have shown, Ramana's image as a timeless and purely spiritual proponent of Advaita Vedānta is indebted to historical processes, yet scholars such as Forsthoefel, Sharma and Kinsley have too readily assumed this image as an accurate representation, and thus consolidated it. In contrast to recent scholarly representations of Ramana, which tend to be reverential, I have demonstrated that he was very much a product of and important to his time, connected to the political sphere in several ways and more accurately identified with the Tamil Śaiva bhakti tradition. The current study has therefore revealed the ways that scholarship can misinterpret and misrepresent religious figures because of the failure to maintain critical distance when dealing with the rhetoric of devotional literature. As Bruce Lincoln succinctly puts it, "Reverence is a religious, and not a scholarly virtue."3

Furthermore, the approach of scholars who misrepresented Ramana's life and teachings has called into question any scholarly discourse on Asian religious figures or systems that analysed its subject solely in an ahistorical and philosophical way. This approach - which follows in the footsteps of Orientalists who interpreted and presented Indian philosophy as timeless - has reminded us of

\footnotetext{
${ }^{3}$ Bruce Lincoln, "Theses on method," Method and Theory in the Study of Religion 8 (1996): 226.
} 
the need to situate religious individuals, groups and philosophical systems in their historical context if we wish to better understand them. Moreover, an historical and critical approach towards Ramana's alleged 'awakening' has allowed me to demonstrate the ways in which religious experience may be manipulated to serve religious, political and scholarly agendas. Thus any scholarly work that analyses religious experience in a way that ignores social, political, cultural and historical contexts should be approached in an especially critical manner. Finally, the failure of scholars to take an historical approach in their analysis of Ramana Maharshi has meant that they failed to recognise the presence of Orientalism in the processes that determined his status as a Maharshi and Advaitin, as well as his image as a timeless and purely spiritual figure. Such scholarly representations have therefore participated in and continued a type of discourse that unfortunately has yet to become a matter of history. 


\section{$\underline{\text { Bibliography }}$}

Aleaz, K. P. Harmony of Religions: the Relevance of Swami Vivekananda. Calcutta: Punthi-Pushtak, 1993.

Arberry, A. J. "Thomas, Frederick William (1867-1956)." Oxford Dictionary of National Biography. http://www.oxforddnb.com/view/article/36472 (accessed 10 Aug 2011).

Arnold, David. Gandhi: Profiles in Power. New York: Longman, 2001.

Arunachala's Ramana, Ocean of Boundless Grace, 8 vols. Tiruvannamalai: Sri Ramanasraman, 2007.

Balagangadhara, S. N. “Orientalism, Postcolonialism and the 'Construction' of Religion." In Rethinking Religion in India, ed. Esther Bloch, Marianne Keppens and Rajaram Hegde, 135-163. London: Routledge, 2010.

Bandyopadhyay, S. From Plassey to Partition: a History of Modern India. New Delhi: Orient Longman, 2004.

Bandyopadhyay, Sekhar. "Introduction." In Nationalist Movement in India: a Reader, ed. Sekhar Bandyopadhyay, xv-xliii. Oxford: Oxford University Press, 2009.

Bandyopadhyay, Sekhar, ed. Nationalist Movement in India: a Reader. Oxford: Oxford University Press, 2009.

Bate, Bernard. "Arumuga Navalar, Saivite Sermons, and the delimitation of religion, c.1850." The Indian Economic and Social History Review 42, no.4 (2005): 469-484.

Bhagavad Gìtā. Translated by Juan Mascaro. New Delhi: Penguin Classics, 1962.

Bhatt, Chetan. Hindu Nationalism: Origins, Ideologies and Modern Myths. Oxford: Berg, 2001.

Bhikshu, Krishna. Sri Ramana Leela. Translated by Pingali Surya Sundaram. Tiruvannamalai: Sri Ramanasramam, 2003.

Brekke, Torkel. Makers of Modern Indian Religion in the Late Nineteenth Century. Oxford: Oxford University Press, 2002.

Brekke, Torkel. "The Conceptual Foundation of Missionary Hinduism." The Journal of Religious History 23 no. 2 (1999): 203-214.

Brunton, Paul. A Search in Secret India. London: Ryder and Co., 1947.

Brunton, Paul. The Maharshi and His Message. Tiruvannamalai: Sri Ramanasramam, 2000. 
Chadwick, Major A. W. A Sadhu's Reminiscences. Tiruvannamalai: Sri Ramanasramam, 2005.

Chandra, Bipan. Nationalism and Colonialism in Modern India. New Delhi: Orient Longman, 1984.

Chatterji, Bankim Chandra. "Bande Mataram." In Sources of Indian Tradition, vol. II, ed. and revised by Stephen N. Hay, 159-60. New York: Columbia University Press, 1988.

Chatterjee, Margaret. Gandhi's Religious Thought. Notre Dame, Indiana: University of Notre Dame Press, 1983.

Chatterjee, Partha. "History and the Nationalization of Hinduism." Social Research 59, no.1 (1992): 111-149.

Chatterjee, Partha. "The Nationalist Resolution of the Women's Question." In Recasting Women: Essays in Indian Colonial History, ed. Kumkum Sangari and Sudesh Vaid, 233-253. New Brunswick, New Jersey: Rutgers University Press, 1990.

Chattopadhyaya, Rajagopal. Swami Vivekananda in India: A Corrective Biography Delhi, Motilal Banarsidass, 1999.

Chowdhury-Sengupta, Indira. "Reconstructing Hinduism." In Swami Vivekananda and the Modernization of Hinduism, ed. William Radice, 17-35. New York: Oxford University Press, 1998.

Cohen, S. S. Guru Ramana. Tiruvannamalai: Sri Ramanasramam, 2003.

Crawford, S. Cromwell. Ram Mohan Roy: Social Political and Religious Reform in $19^{\text {th }}$ Century India. New York: Paragon House Publishers, 1987.

Dayanandan, Francis, T. Tamil Shaivism and the Transcending Message of Ramalinga Swamy. Chennai: Institute of Asian Studies, 2006.

Dayanandan, Francis, T. The Mission and Message of Ramalinga Swamy. Delhi: Mtilal Banarsidass, 1990.

De Bary, Wm. Theodore, ed. Sources of Indian Tradition, vol. II. New York: Columbia University Press, 1958.

Dirks, Nicholas B. Castes of Mind: Colonialism and the Making of Modern India. Princeton: Princeton University Press, 2001.

Dodson, Michael S. Orientalism, Empire, and National Culture: India 1770-1880. New York: Palgrave Macmillan, 2007.

Fischer. Louis, ed. The Essential Gandhi: an Anthology of his Life, Work and Ideas. New York: Vintage Books, 2002. 
Heehs. Peter, ed. The Essential Writings of Sri Aurobindo. New York: Oxford University Press, 1998.

Gandhi, M. K. "Hind Swaraj." In Sources of Indian Tradition, vol. II, ed. De Bary, Wm. Theodore, 251-67. New York: Columbia University Press, 1958

Godman. David, ed. Final Talks: Annamalai Swami. Boulder: David Godman Avadhuta Foundation, 2006.

Flood, Gavin. An Introduction to Hinduism. Cambridge: Cambridge University Press, 1996.

Fort, Andrew O. Jivvanmukti in Transformation: Embodied Liberation in Advaita and Neo-Vedanta. New York: State University of New York Press, 1998.

Forsthoefel, Thomas A. Knowing Beyond Knowledge: Epistemologies of Religious Experience in Classical and Modern Advaita. Burlington: Ashgate Publishing Company, 2002.

Forsthoefel, Thomas A. "Ramana Maharshi: Mystic as Translator." International Journal of Hindu Studies 5 (2001): 109-130.

Forsthoefel, Thomas A. "The Sage of Pure Experience: the Appeal of Ramana Maharshi in the West." Journal of Hindu-Christian Studies Bulletin 14 (2001): 3136.

Forsthoefel, Thomas A. "Weaving the inward thread to awakening: the perennial appeal of Ramana Maharshi.” Horizons 29 (2002): 240-259.

Frykenberg, Robert E. 'The Emergence of Modern 'Hinduism' as a Concept and as an Institution: a Reappraisal with Special Reference to South India." In Hinduism Reconsidered, ed. Gunther D. Sontheimer and Hermann Kulke, 29-50. New Delhi: Ramesh Jain Manohar Publications, 1989.

Godman, David. Be As You Are: The Teaching of Sri Ramana Maharshi. London: Penguin, 1992.

Godman, David. Living by the Words of Bhagavan. Tiruvannamalai: Sri Annamalai Swami Ashram Trust, 1994.

Godman, David. No Mind - I Am the Self: The Lives and Teaching of Sri Lakshmana Swamy and Mathru Sri Sarada. Nellore: Sri Lakshmana Ashram, 2005.

Golden Jubilee Souvenir. Tiruvannamalai: Sri Ramanasramam, 1946.

Grimes, John. Ramana Maharshi: the Crown Jewel of Advaita. Varanasi: Indica Books, 2010.

Hacker, Paul. "Aspects of Neo-Hinduism as Contrasted with Surviving Traditional Hinduism." In Philology and Confrontation: Paul Hacker on Traditional and 
Modern Vedanta, ed. Wilhelm Halbfass, 229-57. Albany: State University of New York Press, 1995.

Halbfass, Wilhelm. India and Europe: and Essay in Understanding. Albany: State University of New York Press, 1988.

Halbfass, Wilhelm, ed. Philology and Confrontation: Paul Hacker on Traditional and Modern Vedanta. Albany: State University of New York Press, 1995.

Hellmann-Rajanayagam, Dagmar. "Arumuka Navalar: Religious reformer or national leader of Eelam." The Indian Economic and Social History Review 26, no.2 (1989): 235-257.

Hudson, D. Dennis. "Arumuga Navalar and the Hindu Renaissance Among the Tamils." In Religious Controversy in British India: Dialogues in South Asian Languages, ed. Kenneth W. Jones, 27-51. Albany: State University of New York Press, 1992.

Hudson, Dennis. "Winning Souls for Siva: Arumuga Navalar's Transmission of the Saiva Religion." In A Sacred Thread: Modern Transmissions of Hindu Traditions in India and Abroad, ed. Raymond Brady Williams, 23-51. Chambersburg: Anima Publications, 1992.

Humphreys, Frank H. Glimpses of the Life and Teachings of Bhagavan Sri Ramana Maharshi. Tiruvannamalai: Sri Ramanasramam, 1999.

Inden, Ronald. Imagining India. Oxford: Blackwell Publishers, 1990.

Islam, Shamsul, Religious Dimensions of Indian Nationalism: a study of RSS. Delhi, Media House, 2006.

Iyer, T. K. Sundaresa. At the Feet of Bhagavan. Tiruvannamalai: Sri Ramanasramam, 2005.

Jaffrelot, Christophe, ed. Hindu Nationalism: A Reader. New Jersey: Princeton University Press, 2007.

Jaffrelot, Christophe. The Hindu Nationalist Movement and Indian Politics: 1925 to the 1990s: Strategies of Identity Building, Implantation and Mobilisation. London: Hurst and Company, 1996.

Jordens, J. T. F. Gandhi's Religion: a Homespun Shawl. Basingstoke: Macmillan, 1998.

Jung, Carl G. "Sri Ramana and His Message to Modern Man." In Golden Jubilee Souvenir, 114-17. Tiruvannamalai: Sri Ramanasramam, 1946.

Kamath, M. S. My Motherland. Madras: The Sunday Times, Office. 
Kamath, M. S. Sri Ramana Maharshi: a Biography with 111 Illustrations. Madras: The Sunday Times Bookshop, 1936.

Katz, Steven T. Mysticism and Philosophical Analysis. New York: Oxford University Press, 1978.

King, Richard. "Colonialism, Hinduism and the Discourse of Religion." In Rethinking Religion in India, ed. Esther Bloch, Marianne Keppens and Rajaram Hegde, 95-112. London: Routledge, 2010.

King, Richard. Indian Philosophy: an Introduction to Hindu and Buddhist Thought. Washington D. C: Georgetown University Press, 1999.

King, Richard, Orientalism and Religion: Post-colonial Theory, India and the Mystic East. New York: Routledge, 1999.

Kinsley, David R. Hinduism: a Cultural Perspective. New Jersey: Prentice-Hall, 1982.

Kopf, David. British Orientalism and Bengal Renaissance; the Dynamics of Indian Modernization. Berkeley: University of California Press, 1969.

Kunju Swami. Living with the Master. Tiruvannamalai: Sri Ramanasramam, 2008.

Lakshmikantam, Gunturu. Nayana: Kavyakantha Vasistha Ganapati Muni. Translated by Dr G. Krishna. Hyderabad: Raghavendra Graphics, 1978.

Larson, Gerald James. Classical Sāmpkhya: an Interpretation of its History and Meaning. Delhi: Motilal Banarsidass, 2001.

Lincoln, Bruce. "Theses on method." Method and Theory in the Study of Religion 8 (1996): 225-27.

Ludden, David E., ed. Making India Hindu: Religion, Community and the Politics of Democracy in India. Delhi: Oxford University Press, 2005.

Mahadevan, T. M. P. Arunachala Siva. Tiruvannamalai: Sri Ramanasramam, 2005.

Mahadevan, T. M. P. Bhagavan Ramana. Tiruvannamalai: Sri Ramanasramam, 1989.

Maharshi, Ramana. Who Am I?: The Teachings of Bhagavan Sri Ramana Maharshi. Tiruvannamalai: Sri Ramanasramam, 2007.

Masselos, Jim. Indian Nationalism: a History. New Delhi: Sterling Publishers, 2002.

McGlashan, Alaister. The History of the Holy Servants of Lord Siva: a translation of the Periya Puranam of Cekkilar. Victoria, BC: Trafford Publishing, 2006. 
Metcalf, Barbara Daly. "Imagining Community: Polemical Debates in Colonial India." In Religious Controversy in British India: Dialogues in South Asian Languages, ed. Kenneth W. Jones, 229-240. Albany: State University of New York Press, 1992.

Mitchiner, John E. Traditions of the Seven Rishis. Delhi: Motilal Banarsidass, 2000.

Mudaliar, A. Devaraja. Day by Day with Bhagavan. Tiruvannamalai: Sri Ramanasramam, 2002.

Mudaliar, A. Devaraja, ed. Gems from Bhagavan. Tiruvannamalai: Sri Ramanasramam, 2000.

Mudaliar, A. Devaraja. My Recollections of Bhagavan Sri Ramana. Tiruvannamalai: Sri Ramanasramam, 2009.

Muni, Vasishtha Ganapati. Epistles of Light: Letters from Vasishtha Kavyakantha Ganapati Muni to Bhagavan Sri Ramana Maharshi. Tiruvannamalai: Sri Ramanasramam, 2006.

Muni, Vasishtha Ganapati. Sri Ramana Gita. Translated by K. Swaminathan. Tiruvannamalai: Sri Ramanasramam, 2004.

Murunagar. Padamalai: Teachings of Sri Ramana Maharshi. Translated by Dr T.V. Venkatasubramanian, Robert Butler, David Godman. Boulder: David Godman Avadhuta Foundation, 2005.

Nagamma, Suri. Letters from Sri Ramanasramam, 2 vols. Translated by D. S. Sastri. Tiruvannamalai: Sri Ramanasramam, 2006.

Narain. Laxmi, ed. Face to Face with Sri Ramana Maharshi: Enchanting and Uplifting Reminiscences of 160 Persons. Hyderabad: Sri Ramana Kendram, 2007.

Narasimha Swami, B. V. Self Realization: the Life and Teachings of Bhagavan Sri Ramana Maharshi. Tiruvannamalai: Sri Ramanasramam, 2007.

Natesan. "Kavyakantha." In Ramana Smrti, 111-14. Tiruvannamalai: Sri Ramanasramam, 1980.

New Revised Standard Version Bible: Harper Study Bible. Edited by Verlyn D. Verbrugge. Grand Rapids, Michigan: Zondervan, 1991.

Osborne, Arthur, ed. The Collected Works of Sri Ramana. Tiruvannamalai: Sri Ramanasraman, 2004.

Osborne, Arthur. Ramana Maharshi and the Path of Self-Knowledge. London: Rider and Company, 1970.

Osborne, Arthur. Teachings of Sri Ramana Maharshi in His Own Words. Tiruvannamalai: Sri Ramanasraman, 2005. 
Pandey, Dhanpati. The Arya Samaj and Indian Nationalism, 1875-1920. New Delhi: S. Chand, 1972.

Pandey, Gyandrey, ed. Hindus and Others: the Question of Identity in India Today. New Delhi: Viking, 1993.

Peterson, Indira Viswanathan. Poems to Siva: the Hymns of the Tamil Saints. Delhi: Motilal Banarsidass, 2007.

Radhakrishnan, S. "Bhagavan Sri Ramana: Sustainer of Spiritual Reality." In Golden Jubilee Souvenir, 29-35. Tiruvannamalai: Sri Ramanasramam, 1946.

Radhakrishnan, Sarvepalli, and Charles A. Moore, ed. A Source Book in Indian Philosophy. Princeton: Princeton University Press, 1957.

Radice, William, ed. Swami Vivekananda and the Modernization of Hinduism. New York: Oxford University Press, 1998.

Ramana, A. V. Maha Tapasvi: The Life Story of Kavyakantha Ganapati Muni. Translated by Sonti Anasuyamma. Tiruvanammalai: Sri Ramanasramam, 2009.

Ramana's Arunachala: Ocean of Divine Grace. Tiruvannamalai: Sri Ramanasraman, 2004.

Ramanan, V. S. "Publisher's Note." In Self Realization: the Life and Teachings of Bhagavan Sri Ramana Maharshi, iii-v. Tiruvannamalai: Sri Ramanasramam, 2007

Raychaudhuri, Tapan. Europe Reconsidered: Perceptions of the West in Nineteenth Century Bengal. Delhi: Oxford University Press, 1988.

Raychaudhuri, Tapan. "Swami Vivekananda's Construction of Hinduism." In Swami Vivekananda and the Modernization of Hinduism, ed. William Radice, 1-16. New York: Oxford University Press, 1998.

Reddy, N. Balarama. My Reminiscences. Tiruvannamalai: Sri Ramanasramam, 2008 .

Rudolf, Lloyd I., and Sussane Hoeber Rudolf. The Modernity of Tradition: Political Development in India. Chicago: The University of Chicago Press, 1967.

Said, Edward. Orientalism. London: Routledge \& Kegan Paul, 1978.

Sargeant, Winthrop. "Holy Man.” Life Magazine, May 30, 1949. http://books.google.com/books?id=1k4EAAAAMBAJ\&pg=PA92\&source=gbs toc r $\&$ cad $=2 \# \mathrm{v}=$ onepage $\& q \& \mathrm{f}=$ false $($ accessed 25 June, 2010).

Sastrigal, Kuzumani N. Seshadri Swamigal of Tiruvannamalai. Translated by S.A. Subramanian. Mumbai: Bhavan's Book University, 1998. 
Sastry, T. V. Kapali. Collected Works of T. V. Kapali Sastry, 7 vols. Pondicherry: Dipti Publications, 1983.

Schopen, Gregory. "Archaeology and Protestant Presuppositions in the study of Indian Buddhism." History of Religions 31 (1991): 1-23.

Seal, Anil. The Emergence of Indian Nationalism: Competition and Collaboration in the Later Nineteenth Century. London: Cambridge University Press, 1968.

Sharma, Arvind. "Jīvanmukti in Neo-Hinduism: the Case of Ramana Maharshi." Asian Philosophy 15, no. 3 (2005): 207-220.

Sharma, Arvind. Modern Hindu Thought: The Essential Texts. New Delhi: Oxford University Press, 2002.

Sharma, Arvind. "Predetermination and free will in the teaching of Ramana Maharsi (1879-1950)." Religious Studies 20 (1984): 615-626.

Sharma, Arvind. The Experiential Dimension of Advaita Vedanta. Delhi: Motilal Banarsidass, 1993.

Sharma, Jyotirmaya. Hindutva: Exploring the idea of Hindu Nationalism. New Delhi: Viking, 2003.

Smith, David. Hinduism and Modernity. Oxford: Blackwell, 2003.

Sontheimer, Gunther D., and Hermann Kulke, ed. Hinduism Reconsidered. New Delhi: Ramesh Jain, 1991.

Stace, Walter T. Teachings of the Mystics. New York: Mentor Books, 1960.

Thapar, Romila. "Imagined Religious Communities? Ancient History and the Modern Search for a Hindu Identity.” Modern Asia Studies 23, no.2 (1989): 209231.

Srinivasan, P. R., and Reiniche, Marie Louise. Tiruvannamalai: A Saiva Complex: Inscriptions 1.1. Pondicherry: Institut Francais, 1994.

Veer, Peter van der. Imperial Encounters: Religion and Modernity in India and Britain. New Delhi: Permanent Black, 2006.

Veer, Peter van der. Religious Nationalism: Hindus and Muslims in India. Berkely: University of California Press, 1994.

Vanmikanathan, G. Pathway to God trod by Raamalinga Swaamikal. Bombay: Bharatiya Vidya Bhavan, 1976.

Vanmikanathan, G. Ramalingar. New Delhi: Sahitya Akademi, 1980. 
Venkataramiah, Munagala S. Talks with Sri Ramana Maharshi. Tiruvannamalai: Sri Ramanasramam, 2006.

Vivekananda, Swami. Selections from Swami Vivekananda. Calcutta: Advaita Ashram, 1963.

Vivekananda, Swami. The Complete Works of Swami Vivekananda, 8 vols. Calcutta: Advaita Ashrama, 1964.

Von Stietencron, Heinrich. "Hinduism: on the Proper Use of a Deceptive Term." In Hinduism Reconsidered, ed. Gunther D. Sontheimer and Hermann Kulke, 11-28. New Delhi: Ramesh Jain Manohar Publications, 1989. 
